\title{
A situation analysis of care and support for rape survivors at first point of contact in India and Bangladesh
}

\author{
M.E. Khan \\ Population Council \\ Aruna Bhattacharya \\ Population Council \\ Ismat Bhuiya \\ Population Council \\ Aditi Aeron
}

Follow this and additional works at: https://knowledgecommons.popcouncil.org/departments_sbsr-rh

Part of the Domestic and Intimate Partner Violence Commons, Health Services Research Commons, and the International Public Health Commons How does access to this work benefit you? Let us know!

\section{Recommended Citation}

Khan, M.E., Aruna Bhattacharya, Ismat Bhuiya, and Aditi Aeron. 2008. "A situation analysis of care and support for rape survivors at first point of contact in India and Bangladesh," FRONTIERS Final Report. Washington, DC: Population Council. 


\title{
A Situation Analysis of Care and Support for Rape Survivors at First Point of Contact in India and Bangladesh
}

\author{
M.E. Khan \\ Aruna Bhattacharya \\ Ismat Bhuiya \\ Aditi Aeron
}

September 2008

this study was made possible by the generous support of the American people through the United States Agency for International Development (USAID) under the terms of Cooperative Agreement No. HRN-A00-98-00012-00 and In-house Project number 5800.53122. The contents are the responsibility of the FRONTIERS Program and do not necessarily reflect the views of USAID or the United States Government.
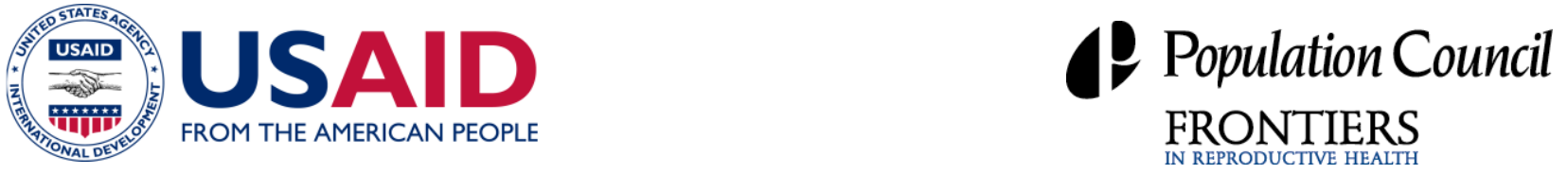


\section{EXECUTIVE SUMMARY}

\section{Background}

Rape survivors need timely medical attention and counseling. The first component of the comprehensive package of care and support that rape survivors need is the immediate counseling and services available at the primary place of contact - often the police station or the hospital. Currently, very little is known about the reproductive health (RH) services offered at these first points of contact. Rape is seen as a medico-legal case in many countries and therefore there are administrative and legal formalities associated with the visit of rape survivors the health facilities. Many times, paperwork and these administrative obligations delay rape survivors' access to some RH services, such as emergency contraception pills (ECP) or post exposure prophylaxis (PEP), because many of these services have small windows of time (72 hours) in which they can be administered effectively. Unless health service staff are aware and able, many of these women may miss their opportunity to obtain certain RH and HIV forms of care.

\section{Study objective}

To evaluate the current environment, a situation analysis of post-rape care services available at the first point of contact was conducted. The aim of this investigation was to gather information that could be used in the development of a comprehensive care and support system for the rape survivor. Secondarily, the study field-tested sensitive and practical tools that could be used in the future for large-scale situation analyses of the rape survivor services. This study was carried out in three cities in India (Delhi, Lucknow, and Vadodara) and four cities in Bangladesh (Dhaka, Chittagong, Sylhet and Tangail).

\section{Methodology}

This study included a situation analysis of both police stations and health facilities, two of the most common points of first contact with service providers for rape survivors. The study tools were developed after reviewing existing instruments utilized by the following organizations: Sexual Violence Research Initiative; Liverpool VCT (a Kenyan NGO); the FRONTIERS Program; and a Population Council multi-country rape survival study in several African countries. After research and development of a study tool, it was pre-tested in Dhaka and Delhi, modified wherever where necessary and re-administered. Data were collected using the final version of the tool with medical practitioners and nurses from public hospitals, and police personnel from stations located near to health facilities.

\section{Findings}

The results demonstrated that there is no uniform service provision protocol to follow for managing rape survivors at health facilities in India or Bangladesh. A protocol was said to exist, yet no copy was available in any of the police stations included in the study, and many police officers interviewed were not even aware of its existence. In most places, the elected procedure for managing rape survivors was based on traditional practices at these stations. 
In both countries, none of the police stations were providing RH services or information on ECP or PEP. According to police officers interviewed, their responsibility ends once the First Information Report (FIR) has been filed and the survivor has been taken to the hospital. Police personnel reported receiving little or no on-the job training on managing and/or counseling rape survivors.

A similar lack of services was observed in hospitals. Sexually transmitted infection (STI) management was not available in most health facilities, and when services were available they were not of any standard regimen. Referrals to VCT centers were rarely seen and PEP was an unfamiliar concept among health professionals. In most hospitals, neither PEP nor ECP was in stock. Skilled counselors were not regularly available in both India and Bangladesh and, similar to the situation in police stations, most doctors and nurses had no orientation on managing rape survivors.

It was clear that most police and medical providers were not sensitive to the needs and care of rape survivors. Interviewees many times reflected thoughts consistent with popular stereotypes towards rape survivors, blaming the survivor, emphasizing shame brought to the woman's family and a general lack of sympathy for rape survivors.

In Bangladesh, there were six dedicated centers for care and support for rape survivors-One Stop Crisis Centers (OCC) - that have been established to provide comprehensive services to rape survivors and survivors of other violent crimes. These OCCs should be studied further in detail as they may act as models for the provision of comprehensive care and support to rape survivors within the country and regionally.

It is important to note that these results should not be generalized because the sample sizes were small. Despite this limitation, the study findings are striking and provide a good lead for a fullscale situation analysis of the police stations and health facilities that may potentially provide services to these women in need.

The tools in this study were developed, revised and tested. In general, the tools were found to be efficient and may be applicable for use in a number of diverse settings. Unfortunately, because the situation analyzed in this setting was so dire, many questions were left unanswered as they were not applicable. To complement these findings, qualitative data should also be collected to get a fuller picture. As a comprehensive analysis, this information can lend to an overall understanding of types and quality of services provided to rape survivors. 


\section{TABLE OF CONTENTS}

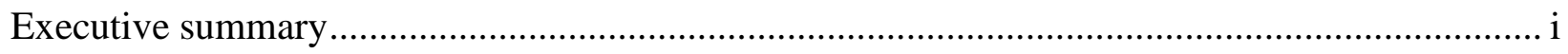

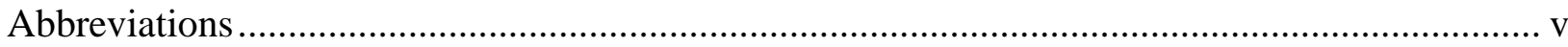

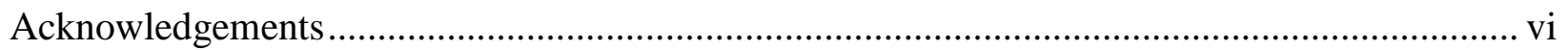

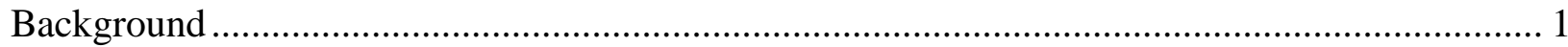

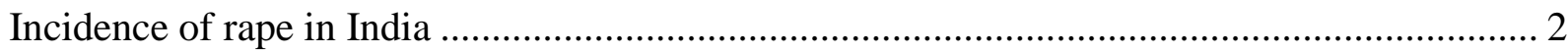

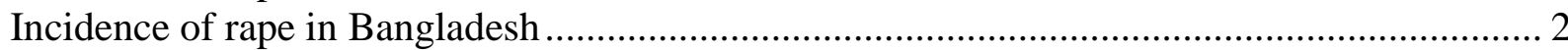

Consequences of rape and services for survivors ………………......................................... 3

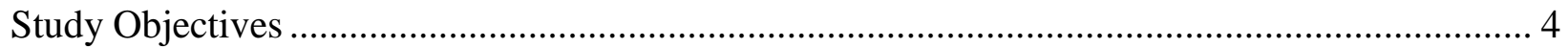

Research questions ....................................................................................................... 4

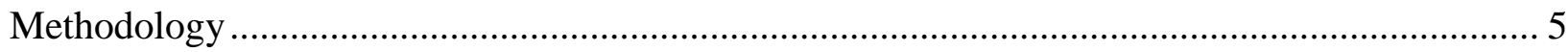

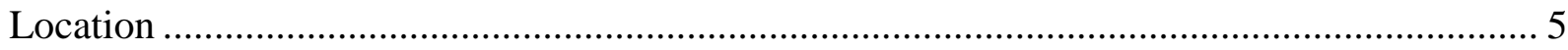

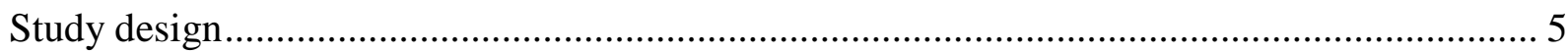

Implementation of the study ...................................................................................... 5

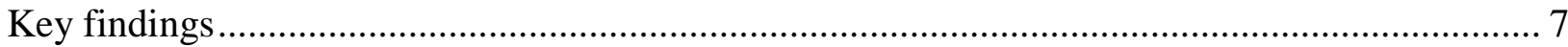

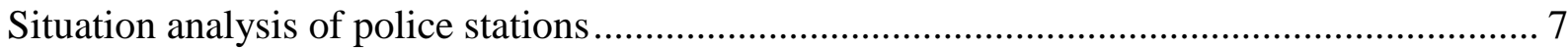

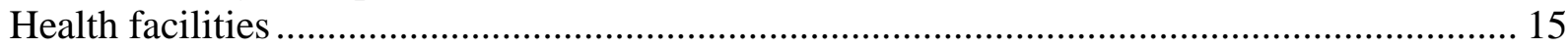

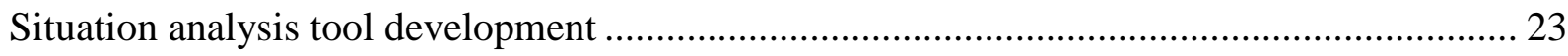

Lessons learned and recommendations............................................................................... 23

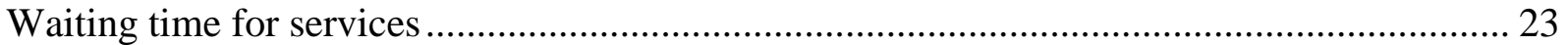

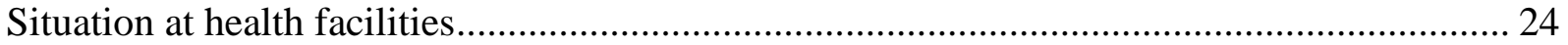

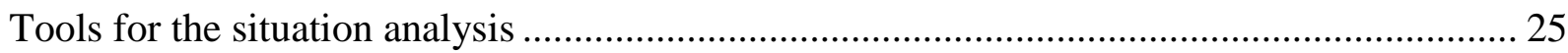

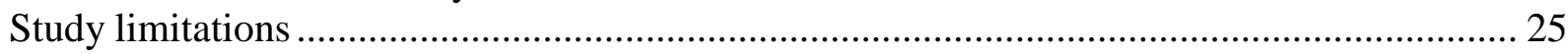

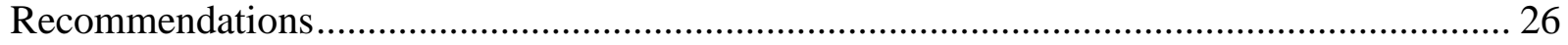

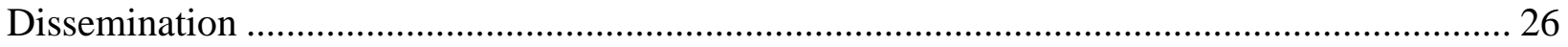

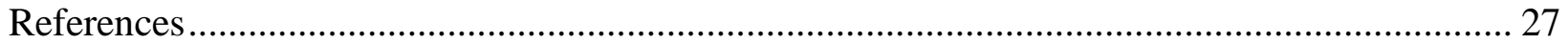




\section{List of Tables}

Table 1: Percentage of rape cases first reported at the police station …................................... 7

Table 2: Rape cases handled at police stations (percentage) ............................................... 7

Table 4: Information to rape survivors on danger of getting STI/HIV (percentage)................. 11

Table 5: Discussion of possibility of pregnancy (percentage) .............................................. 11

Table 6: Attitude of police personnel towards rape survivors in India $(\mathrm{N}=16)$ and Bangladesh

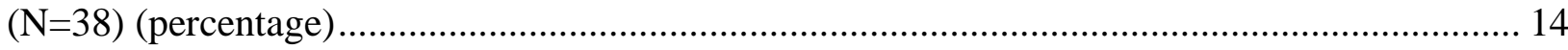

Table 7: Samples collected during examination of rape survivors for forensic tests (percentage)

Table 8: STI prevention for rape survivors at health facilities (percentage) ............................. 18

Table 9: HIV prevention services offered at the health facility (percentage) ........................... 19

Table 10: Provision of emergency contraception to rape survivors (percentage) ...................... 19

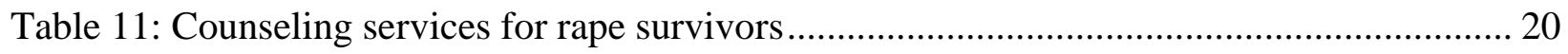

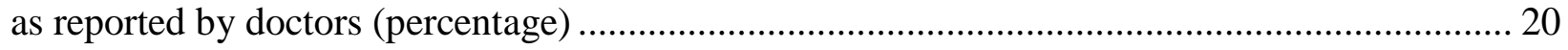

Table 12: Attitude of health care providers towards rape survivors in India and Bangladesh ..... 22 


\section{ABBREVIATIONS}

\begin{tabular}{|c|c|}
\hline AIDS & Acquired Immune Deficiency Syndrome \\
\hline ART & Anti Retroviral Therapy \\
\hline DTC & Diagnostic testing and counseling \\
\hline $\mathrm{EC}$ & Emergency Contraception \\
\hline $\mathrm{ECP}$ & Emergency Contraceptive Pills \\
\hline FIR & First Information Report \\
\hline $\mathrm{FP}$ & Family Planning \\
\hline FRONTIERS & Frontiers in Reproductive Health Program \\
\hline GA & General Anesthesia \\
\hline HIV & Human Immune Deficiency virus \\
\hline HOD & Head of the Department \\
\hline HQ & Headquarters \\
\hline ICRW & International Center for Research on Women \\
\hline $\mathrm{IO}$ & Investigating Officer \\
\hline IPC & Indian Penal Code \\
\hline LPO & Lady Police Officer \\
\hline MLC & Medico Legal Case \\
\hline NCRB & National Crime Records Bureau \\
\hline NGO & Non Governmental Organization \\
\hline NFHS & National Family Health Survey \\
\hline $\mathrm{OCC}$ & One Stop Crisis Center \\
\hline $\mathrm{OCP}$ & Oral Contraceptive Pills \\
\hline OTC & Over the Counter \\
\hline PEP & Post Exposure Prophylaxis \\
\hline PV & Per Vaginal \\
\hline $\mathrm{RH}$ & Reproductive Health \\
\hline SA & Situation Analysis \\
\hline $\mathrm{SHO}$ & Station House Officer \\
\hline STDs & Sexually Transmitted Diseases \\
\hline STIs & Sexually Transmitted Infections \\
\hline SV & Sexual Violence \\
\hline SVRI & Sexual Violence Research Initiative \\
\hline UPS & Unprotected Sex \\
\hline USAID & United States Agency for International Development \\
\hline VCT & Voluntary Counseling and Testing \\
\hline VAW & Violence against Women \\
\hline WHO & World Health Organization \\
\hline
\end{tabular}




\section{ACKNOWLEDGEMENTS}

This was a multi-country study undertaken by FRONTIERS Program of the Population Council.

We are thankful to the Police Commissioners of Delhi Police, and senior police officials of Lucknow in Uttar Pradesh and Vadodara in Gujarat for cooperating during data collection in India. We also thank the Medical Superintendents of Safdarjung Hospital, Delhi, Babu Jagjivan Ram Hospital, Jahangir Puri, Delhi, Deen Dayal Upadhaya Hospital, Hari Nagar, Delhi, Kings George Medical College and Hospital, Lucknow, Dafreen Hospital (Avanti Bai Mahila Chikitsalay), Lucknow and Sawai S G Hospital, Vadodara for allowing us to interview the HODs of the Department of Obstetrics and Gynecology and the Department of Forensic Science and the Medical Officers in-charge of casualty wards. The Medical Superintendents of the medical colleges and hospitals and Police Commissioners of the three cities where the study was carried out encouraged the study and made sure that the research protocol was fulfilled. Special mentions need to be made of the various doctors and paramedics who participated in the interview sessions and we acknowledge their valuable contribution.

We express our gratitude to the Principals of Dhaka Medical College Hospital (DMCH), Chittagong Medical College Hospital (CMCH), Sylhet Medical College Hospital (SMCH), and Civil Surgeon of Tangail District Hospital in Bangladesh for their extensive support to conduct the study. We are thankful to doctors working at the Department of Forensic Medicine (FM), Department of Gynae and Obstetrics, and Emergency Department, doctors working at One Stop Crisis Centre (OCC) and the Officers In-Charge (OC) in respective Thanas for providing relevant information. Thanks are due to Dr. Shimul Koli Hossain and Dr. Shahadat Hossain for helping us in collecting information.

We are thankful to United States Agency for International Development (USAID) for providing resources. 


\section{BACKGROUND}

Sexual violence is common and found in all parts of the world. These violent acts range from unwanted sexual advances to forced marriage, rape, forced abortion, and the denial of the right to use contraception (WHO 2002). Among these offenses, rape is perhaps the most traumaticdefined by WHO as "physically forced or otherwise coerced penetration-even if slight-of the vulva or anus, using a penis, other body parts or objects" (WHO 2002). However, the definition of rape differs greatly by cultural settings. For example, Box 1 below provides a comparison of the definitions of rape provided by WHO and the Indian Penal Code.

\section{Box 1: Definitions of Rape: No Uniformity}

WHO defines rape as an act where the survivor has been sexually assaulted in any of the following form:

1. Sexually violated

2. Penetrated by force

3. Vaginal penetration, non-consensual

4. Anal penetration, non-consensual

5. Penetrated by an object.

According to WHO's definition, one or any combination of $1,2,3,4$ and 5 are defined as rape.

According to the Indian Penal Code (IPC), only (3) is a rape case. (4) and (5) are cases of sodomy (unnatural sexual acts). (1) and (2) are neither rape cases nor cases of sodomy, but may be considered attempted rape or sexual harassment, depending on the details of the interaction.

Featured sections of the IPC directly addressing sexual assault include:

Section 354: Sexual harassment; attempt to outrage modesty of a woman.

Section 323: Simple assault

Section 377: Sodomy (sexual intercourse against the order of nature)

Section 375: Rape occurs when a man has sexual intercourse with a woman, against her will, without her consent, with her consent, when consent has been obtained by putting her or any person in whom she is interested in fear of death or hurt, with when she believes that he is her husband, with her consent, when consent was given due to unsoundness of mind or intoxication or administration of stupefying/unwholesome substance because of which she is unable to understand the nature and circumstances of her act, with or without consent when she is under 16 years of age. To constitute sexual intercourse, vaginal penetration is essential.

Sexual intercourse by a man with his wife under 15 years of age amounts to rape. Rape is an offense committed by a man upon a woman.

Section 376 / 511: Attempt to rape. 


\section{Incidence of rape in India}

Although the incidence of rape in India is very high, data are scarce. According to the Indian National Crime Records Bureau, in 2005 one crime was committed against a woman every 3 minutes, 1 molestation case was registered every 15 minutes, one sexual harassment case every 53 minutes, and one rape case was reported every 29 minutes (Times News Network 2006). Delhi, the capital city, was recently labeled the "rape capital" of South Asia, with more than 330 rape and molestation cases reported in the first four months of 2008 (Wax 2008). According to "Crime in India" (NCRB 2007) a total of 19,348 rape cases were reported during 2006, marking an increase of five percent from the previous year.

However, these numbers are a grossly underestimated picture of reality. These numbers only reflect rape cases that have been officially reported to the police. But women's groups say that less than two percent of sexually assaulted women actually report the crime to the police (Wax 2008) — resulting in a huge proportion of cases going uncounted. Rape goes unreported for a number of reasons: families may put pressure on the survivors to remain quiet because of honor (especially when the perpetrator is a member of the same family) (WHO 2002 \& 2003), or there may be a lack of faith in law and the judicial system (WHO 2003). In 2006, 74,659 rape cases were due for trial in the Indian Courts; only five percent $(3,806)$ resulted in a conviction. Another reason for vast underestimation is that forced sex or assault committed by a husband on his wife is not considered rape in India. Studies on inter-partner violence in India (NFHS 2007, Koenig et.al. 2006, Khan et al., 2003) have shown considerable incidence of rape and forced sex committed by husbands (10-60 percent). Yet these cases are not reported or acknowledged by the judicial system.

With these two considerations in mind, it is clear that the actual number of rape cases is astronomically higher than what has been officially recognized, exemplifying a most critical situation that warrants attention and intervention.

\section{Incidence of rape in Bangladesh}

The present situation of rape in Bangladesh is similar to that of India. Data from an Odhikar press release on Violence Against Women in Bangladesh revealed that from January 2001 to February 2007, 5,816 women and children were reportedly raped across the country, of which 636 were killed (Coalition for the International Criminal Court 2007). As in India, Bangladeshi human rights monitors report the actual number of rape as being much higher than what is reported officially. Fear of social disgrace and lack of faith in the judicial system (U.S. Department of State 2005, Badruddoza 2002) are two reasons for this underestimate.

Additionally, a rape case must first be registered with the police before action can be taken, and many policemen demand bribes for proceedings with registration. Additionally, pursuing cases from lower to higher courts sometimes takes 2 to 3 years, and most women cannot bear the costs of these lengthy proceedings (Badruddoza 2002). Lastly, sexual violence conducted by husband is not considered an offense, is not counted in national statistics and does not warrant legal proceedings. 


\section{Consequences of rape and services for survivors}

The consequences of rape are both physical and emotional. Survivors of sexual assault suffer from mental stress and other psychological syndromes (NCRB 2006, Pitre 2006). These consequences are more damaging in cultural settings where men are expected to be sexually demanding and where women's sexuality is valued by its "purity" (i.e. avoiding sexual contact before marriage and remaining monogamous after marriage).

These social norms lead to "survivor blaming", laying all burden on the woman, running down their self-esteem and level of empowerment. To appease this social norm, trauma counseling is an important treatment for rape survivors, and should be included in all therapy activities.

Potential ill-health consequences of rape include physical injuries, sexually transmitted infections, including HIV, and pregnancy. Pregnancies resulting from rape are generally unwanted and traumatic, and in countries where abortion is not legal, the effects of the rape may be even more traumatic and long-lasting than the incidence is alone. Timely emergency contraception (EC) to all female rape survivors, who are already not pregnant, ${ }^{1}$ could protect many from unwanted pregnancies. Other reproductive health needs of rape survivors include the prevention of HIV and other STIs with timely administering PEP (post-exposure prophylaxis) (Population Council 2007, WHO 2003, Christofides et al. 2005, Liverpool 2005).

According to Amita Pitre (2006), an important reason for failure of securing convictions of rape offenders is that forensic evidence is not regularly collected or stored with requisite care. Review of sexual violence services in South Asia (Khan et al 2006) led to the identification of several limitations in the existing procedures. Recommendations were made to improve coordination between the police, medical and judicial systems to better elicit justice. Population Council's research on the comprehensive care for rape survivors (Keesbury, et.al. 2006) recommends a comprehensive plan of action, with forensic examinations a key player in justice and medical requirements (see Box 2).

Providing ECP to rape survivors at the first point of contact can be an important entry point to strengthen other RH and related services available to these women. A study by Population Council in Zambia (Keesbury et al. 2006) demonstrated that the majority (91\%) of sexual abuse survivors seek support from the police before seeking healthcare, and therefore some elements of a comprehensive package of care should be made available at these first centers of contact (such as ECP, counseling and information on PEP).

Population Council analyzed the care-seeking behaviors of rape survivors in a South Asian context, in efforts to build a base for a comprehensive package of care. Assessment tools for conducting rapid Situation Analysis (SA) were created and tested to evaluate the services offered at police stations and health facilities. The current report describes the process of development and improvement of these SA tools and some of the salient findings from this analysis.

\footnotetext{
${ }^{1}$ A pregnancy test is desirable to determine the status of eligible females. It is important to reassure clients that the EC pills will cause no harm to an existing fetus or to the course of the pregnancy (WHO 2004).
} 


\section{Box 2: A Comprehensive Model of Care for Rape Survivors}

1. Medical Management of sexual violence at the point of first contact with the survivors (e.g. at the police station or medical facility)

a. Treatment of physical injuries

b. Pregnancy testing and emergency contraception (EC)

c. STI prophylaxis

d. HIV diagnostic testing and counselling (DTC) and Post-Exposure Prophylaxis (PEP)

2. Psychological Counselling of rape survivors

3. Collection of forensic evidence and its documentation that can be used during prosecution

4. Provision of referrals to the survivor in case she wants to initiate prosecution. This will require establishment of strong links between the police and health facility and NGOs so that incidents could be referred in either direction.

(Population Council, 2008)

\section{STUDY OBJECTIVES}

The ultimate aim of this study was to reduce the incidence of sexual violence and meet the reproductive health needs of survivors of sexual violence. The immediate objectives of the present study were:

1. To develop sensitive and practical situation analysis tool(s) for assessing the RH services available at first contact point for rape survivors in diverse settings.

2. To use the tools to conduct a rapid situation analysis of RH and other related services, available at health facility and police stations in three cities in India and four cities in Bangladesh.

3. Based on the experience of the pilot study in the two countries, to revise and finalize the SA tools to facilitate their use in diverse settings.

\section{Research questions}

The key research questions investigated in this situational analysis include:

1. What happens when a rape survivor comes to a health care facility or the police station, reporting a rape incident?

2. Are standard protocols available to examine rape cases and survivors, and collect forensic evidence systematically?

3. Is it feasible to introduce specific reproductive health services in police stations and make them available to rape survivors?

4. What can be done to provide a comprehensive model of care and essential services to survivors of sexual assault? 


\section{METHODOLOGY}

\section{Location}

A situation analysis was conducted in seven cities from two South Asian countries, three in India and four in Bangladesh, reflecting different cultural and administrative settings. The cities in the study were:

- Delhi, Lucknow, and Vadodara in India

- Dhaka, Chittagong, Sylhet and Tangail in Bangladesh.

\section{Study design}

The study was exploratory in nature. It consisted of interviews with medical practitioners and nurses in public hospitals and police personnel in police stations adjacent to medical facilities. Interviewees were asked about the procedures followed and services provided to survivors of sexual assault when they reach the respective facilities. There were specific questions addressing the following: waiting time, counseling, provision of ECP, PEP services and medical and forensic examinations. The interview questionnaire also included sections on the providers' attitudes towards rape survivors and the extent and type of care they deemed necessary and appropriate for managing rape cases.

\section{Implementation of the study}

Study implementation included four stages completed within six months:

1. Development of Situation Analysis (SA) tools

2. Health care providers and police personnel interviews

3. Situation analysis of care provided to rape survivors at police stations and in medical facilities

4. Modification of tools based on field experience and feedback.

\section{Development of situation analysis (SA) tools:}

Development of the situation analysis tools comprised a literature review, question development, review of existing related tools, and an interview outline for personnel from the police and health services. The literature review included research on sexual assault in general, common RH requirements for rape-survivor services, and regional and international recommendations for rape-survivors at the first-point of contact. ${ }^{2}$ Using this information, a list of questions was developed. Information from the Sexual Violence Research Initiative (SVRI 2007), Liverpool VCT (Liverpool 2005), and the Population Council was used to enhance the significance and applicability of the questions. The reference tools had several general themes in common, which were incorporated as far as possible into these tools. These themes/components were as follows:

\footnotetext{
${ }^{2}$ In some parts of the world, the first point of contact could also be the church or legal court (e.g. In Latin America) or village head (in Africa).
} 
1. Procedures undertaken when the patient first reaches the facility and during the initial waiting time.

2. Counseling of rape survivors.

3. Provision of RH services (including ECP, PEP for STI/HIV).

4. Training of police and medical personnel on post-rape care.

5. Availability of standard protocols and guidelines for managing rape cases.

6. Information on medical and forensic tests available at the health facilities.

7. Attitudes of police and medical personnel towards rape and rape survivors

An interview outline was developed and then pre-tested in Delhi and Dhaka. Feedback from pretests was used to modify the interview outline, specifically in terms of accurately capturing the local context and applicability among police and health care personnel. The revised versions of the questionnaires were used to collect information for this pilot situational analysis and are presented below.

\section{Interviews with Health Facility Staff and Police Officers:}

As the topic of these interviews was very sensitive, many police officers and health providers were not interested in participating in the study. The interview required a large time commitment and several visits by the interviewer before interviews were even able to be initiated. Higher level officers (Medical Superintendents in the hospitals and Police Commissioners in police departments) gave permissions to interview participants. This permission was pertinent in retrieving information from police officers and health care providers at designated centers. For any large scale SA undertaken in future, considerable preparatory time and establishing close relationships with authorities involved is critical.

A total of 55 police personnel and 44 medical practitioners were interviewed. In Bangladesh, two providers were often interviewed from the same facility. In India however, only one person was interviewed from each facility; the interviewee was usually the head of the department/police station. Many times, upon seeking an interview from a second person within the same facility, efforts would be stopped. It would be explained that "...nothing new is going to come," or the potential second interviewees would be instructed not to participate.

Data collection many times was challenging. Interviews were conducted in the place of work, and many times interviews were left incomplete because of emergency situations. Finding time to complete all interviews was very difficult and sometimes issues were left unresolved.

\section{Analysis of data and modification of tools}

After data collection was complete, investigators in the two countries reviewed the questionnaires and further modified the content and layout of the tool. They used feedback from the interviews and personal field experience to guide modifications of the tool. The final modified tools are presented in the Appendices A and B. Data were coded, compiled, and then analyzed using SPSS. The salient findings are presented in the Key Findings section. 


\section{KEY FINDINGS}

\section{Situation analysis of police stations}

Rape as a Medico-legal Case:

The First Information Report (FIR) records the details of a crime when reported at the police station after it occurs. In both India and Bangladesh, rape is classified as a medico-legal case, requiring the involvement of the police and an immediate FIR filing. However, rape survivors did not always approach the police stations immediately after the rape incident (Table 1). According to protocol, a rape reported to a health facility is either referred to
Table 1: Percentage of rape cases first reported at the police station

\begin{tabular}{|lcc|}
\hline & $\begin{array}{c}\text { India } \\
(\mathbf{N}=\mathbf{1 7})\end{array}$ & $\begin{array}{c}\text { Bangladesh } \\
(\mathbf{N}=\mathbf{3 8})\end{array}$ \\
\hline $75 \%$ or more & 29 & 42 \\
$50 \%$ & 24 & 26 \\
$25 \%$ or less & 35 & 32 \\
Do not know & 12 & 0 \\
\hline
\end{tabular}

the police station or the police are called to the health facility before the patient is provided medical services.

\section{Who attends a rape survivor:}

According to protocols available within police departments in India, a lady police officer (LPO) should be the investigating officer (IO) for all rape cases. However, only 5 of 17 police respondents (29 percent) said that rape cases were always registered by LPOs, and 2 reported that they themselves had responded to rape cases when the LPO was not there. Almost half of respondents reported that rape cases were attended by whoever is on duty, and not always by LPOs (Table 2).

In Bangladesh, there is no existing protocol dictating what gender the reporting police officer should be. Yet, 26 percent (10 out of 38) of the police personnel reported that rape cases were always attended by LPOs (Table 2).

Visits to the police stations in India revealed that all writers (a designation in the Police Department equivalent to Sub-Inspector rank) were males, and a number of police stations did not have LPOs. There was a shortage of female officers in the police force in both India and Bangladesh. To cope with this shortage, LPOs from adjacent stations were called to stations without LPOs to report and investigate rape cases (65 percent in

\begin{tabular}{|c|c|c|}
\hline & $\begin{array}{c}\text { India } \\
(\mathrm{N}=17)\end{array}$ & $\begin{array}{l}\text { Bangladesh } \\
(\mathrm{N}=38)\end{array}$ \\
\hline \multicolumn{3}{|l|}{ Rape survivor attended by LPO } \\
\hline Always & 29 & 26 \\
\hline Sometimes & 6 & 45 \\
\hline Whosoever on duty & 47 & 29 \\
\hline Lady Constable if LPO not & & \\
\hline there & 12 & 0 \\
\hline Do not know & 6 & 0 \\
\hline \multicolumn{3}{|l|}{ Waiting period before FIR is written } \\
\hline 15 minutes or less & 23 & 5 \\
\hline 20-30 minutes & 59 & 74 \\
\hline $45-50$ minutes & 0 & 8 \\
\hline 1 hour or more & 18 & 13 \\
\hline \multirow{2}{*}{$\begin{array}{l}\text { Interview with survivor in private room } \\
\text { Police personnel with NO formal } \\
\text { training to manage rape cases }\end{array}$} & 77 & 12 \\
\hline & 94 & 84 \\
\hline $\begin{array}{l}\text { Police personnel showed willingness } \\
\text { to attend training on post-rape care }\end{array}$ & 47 & 82 \\
\hline
\end{tabular}


India; 82 percent in Bangladesh). This referral system likely contributed to the extended wait time experience by rape survivors.

\section{Waiting time at police station:}

Rape cases are meant to be considered high priority cases. Unfortunately, interviews revealed that most rape survivors waited at police stations for the same length of time or even longer than other cases.

Women reporting rape cases wait before their cases are registered and also stay at the station throughout the proceedings. Only 23 percent of the police respondents in India and 5 percent in Bangladesh reported registering rape cases within 15 minutes of the survivor's arrival. Threequarters of police personnel interviewed in Bangladesh and 59 percent in India reported a minimum waiting time of 20-30 minutes for FIR forms to be filled (Table 2). Waiting times for case registration were reported to frequently be over one hour (18 percent in India and 13 percent police in Bangladesh).

It was clear that waiting times were reflective of the presence of an LPO. Waiting times increased when an LPO was called from another police station to manage a rape case. At least 3 respondents from India and 17 from Bangladesh reported the LPO's arrival to take more than an hour at times.

In Bangladesh, a similar procedure is followed. The total duration from the time of arrival to the time when rape survivors are sent to medical facilities varies from one to 2.5 hours. Many times this variability depends on the availability of an LPO. The age of the rape survivor (whether she is an adult or a minor) may also affect the waiting and processing time.

\section{Figure 1 - Flow chart of steps taken when rape survivor reports at police station}

\section{Police Facility}

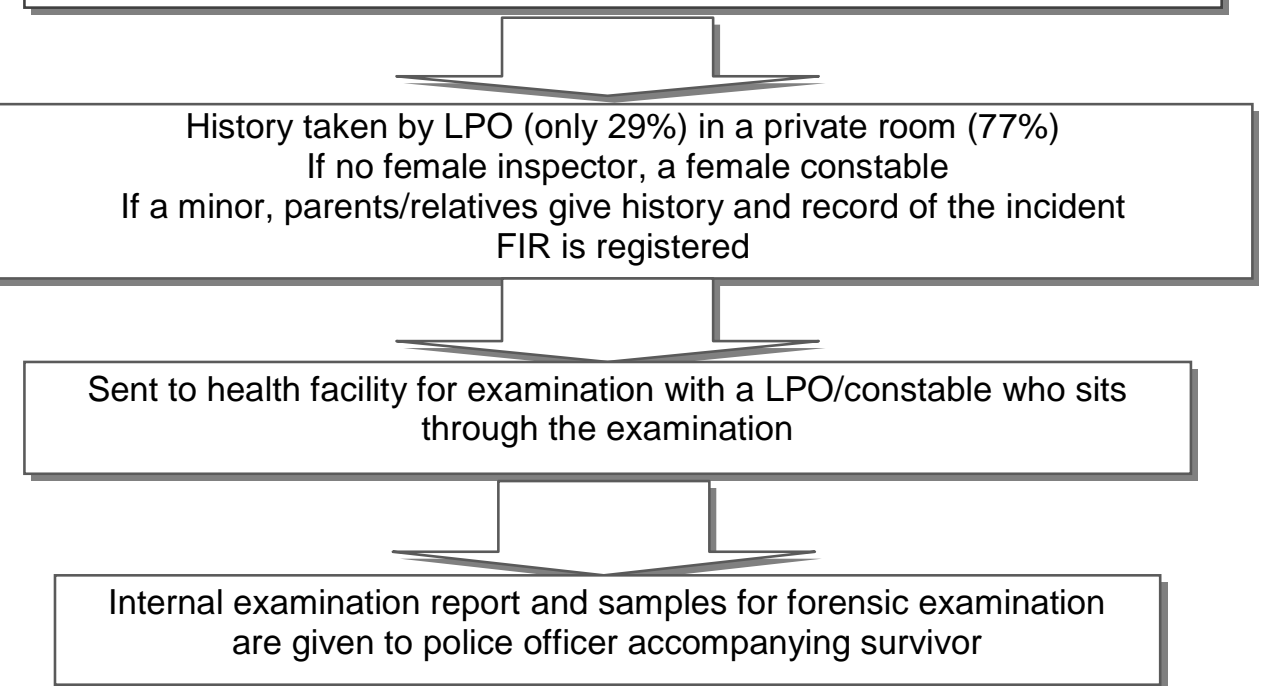




\section{Training on care and support for rape survivors:}

All police personnel received general training before induction into the police force. For noncommissioned officers the training period is one month and for commissioned officers it is one year. Various areas of policing are addressed in these trainings, including the expected role of the police in the case of a rape reported.

During police officer interviews, questions about the existence or the potential for subsequent or more-detailed training were pursued. About 94 percent of the police respondents from India and 84 percent from Bangladesh reported receiving no additional training after joining. However, one police officer in India and six in Bangladesh (16 percent) reported receiving some additional formal training on care and services for rape survivors. In both countries, additional training included medical report documentation, counseling methods, managing juvenile rape cases and managing rape cases during pregnancy. In Bangladesh, however, this additional training was reported to be very general, with the range of topics including managing mentally and physically challenged cases of rape (11 percent), rape laws (11 percent), and forensic evidence collection (11 percent).

Many police officers vocalized interest in receiving additional training on management of rape survivors; 47 percent of the police personnel interviewed in India and 82 percent in Bangladesh demonstrated willingness to attend formal training for managing rape cases. Furthermore, $86-$ 94 percent of all respondents believed that at least two officers/head constables in each police station should be specifically trained to manage rape cases.

\section{Survivors counseling at the police station:}

Counseling may be provided to rape survivors and other survivors of violent crimes in order to assist them with coping strategies, treatment and their mental and physical recovery. Additional to the counseling that may be provided, police officers must interview rape survivors to gather information about the incident for criminal investigation. It is important to distinguish these two terms, counseling and interview, in the following sections.

a. Immediate counseling of the survivor on arrival at the police station: Forty percent of police officers interviewed in India reported that some counseling was provided to the rape survivor before paperwork was completed, in those cases when survivors arrived at the police station in an agitated condition. Forty-seven percent reported waiting until the survivor had calmed down before discussing the police proceedings and the rape incident. A few officers reported initiating interviews without providing any prior counseling or waiting for her to calm down before discussing the incident. 
In Bangladesh, the situation appeared to be quite different, as it was reported that rape survivors were never interviewed when in an agitated state. According to 92 percent of the Bangladeshi police respondents, survivors were first provided with sedatives before discussion or interviews about the rape incident occurred. The remainder said that some counseling was given to the survivor before enquiring about the case (Table 3 ).

\section{b. Counseling of survivor during or after} enquiry: Six police respondents in India and two in Bangladesh reported that no counseling was provided to survivors once the woman had calmed down and legal questioning had begun. Other respondents reported providing some counseling to rape survivors during the registration process (Table 3 ). Counseling to rape survivors seems to be more common in Bangladesh than in India. Unfortunately, the majority of those providing counseling to survivors in both settings were neither trained in

\begin{tabular}{lcc|}
\hline $\begin{array}{l}\text { Table 3: Counseling offered to rape survivors } \\
\text { at the police stations (percentage) }\end{array}$ \\
\hline \multicolumn{1}{|c|}{$\begin{array}{c}\text { India } \\
\text { (N = 15) }\end{array}$} & $\begin{array}{c}\text { Bangladesh } \\
\text { (N = 37) }\end{array}$ \\
\hline $\begin{array}{l}\text { Counseling on arrival } \\
\text { Survivors are given initial } \\
\text { counseling }\end{array}$ & 40 & 8 \\
$\begin{array}{l}\text { Survivors are given } \\
\text { sedatives }\end{array}$ & 0 & 92 \\
$\begin{array}{l}\text { Wait for survivors to calm } \\
\text { down on their own }\end{array}$ & 47 & 0 \\
$\begin{array}{l}\text { Interview the survivors in } \\
\text { the state they came }\end{array}$ & 7 & 0 \\
$\begin{array}{l}\text { Do not know } \\
\text { Counseling during/ after }\end{array}$ & 6 & 0 \\
\hline $\begin{array}{l}\text { enquiry } \\
\text { Yes, always }\end{array}$ & & \\
Yes, if needed & 20 & 68 \\
No & 40 & 24 \\
\hline
\end{tabular}
counseling nor necessarily LPOs assigned to conduct this type of counseling.

Privacy is another important issue and is pertinent for the comfort and confidentiality of the rape survivor. When investigating the proportion of reports that were conducted in privacy, it was reported that in India interviews were mostly conducted in a private room ( 77 percent) and in Bangladesh interviews took place in public interrogation rooms most of the time (82 percent). This lack of privacy (especially in Bangladesh) may directly affect the number of rapes reported to the police and cases pursued legally, as confidentiality and privacy are intricate components the reporting dynamic.

Reproductive health services at police facilities: Most rape survivors have urgent RH needs, including preventative measures that can be taken to prevent an unwanted pregnancy or a sexually transmitted infection. In order to understand what RH services were provided to rape survivors, police personnel in India and Bangladesh were asked about their knowledge of RH services and their availability. The study revealed that police stations in both countries have not taken any actions towards the provision of RH services.

a. STI management and HIVIAIDS prevention: Police officers in India did not provide any information about STIs and HIV infections to rape survivors, nor did they provide or recommend HIV testing for rape survivors. In Bangladesh, 55 percent of the police personnel interviewed reported discussing STIs and HIV with rape survivors, as well as the chances of contracting a disease from the rape incident (Table 4). 


\begin{tabular}{|lcc|}
\hline \multicolumn{3}{|c|}{$\begin{array}{c}\text { Table 4: Information to rape survivors on } \\
\text { danger of getting STI/HIV } \\
\text { (percentage) }\end{array}$} \\
\hline $\begin{array}{l}\text { Informed danger of } \\
\text { HIV }\end{array}$ & $\begin{array}{c}\text { India } \\
(\mathbf{N}=\mathbf{1 7})\end{array}$ & $\begin{array}{c}\text { Bangladesh } \\
(\mathbf{N}=\mathbf{3 8})\end{array}$ \\
\hline Always & 0 & 55 \\
Sometimes/Rarely & 0 & 21 \\
Never & 47 & 21 \\
Don't Know & 53 & 3 \\
\hline
\end{tabular}

Two-thirds of Bangladeshi police officers reported recommending testing for rape survivors, yet none of them provided the tests themselves. When rape survivors enquired about HIV testing, 27 police respondents in Bangladesh but only one in India reported referring survivors to a hospital or VCT centre for possible counseling and testing.

Almost all (95-100 percent) police personnel in India and Bangladesh were unfamiliar with the term and the components of post-exposure prophylaxis (PEP). This component of RH services should be further emphasized in provision of care to rape survivors.

b. Emergency Contraception: All police personnel interviewed in India and 48 percent in Bangladesh admitted to never discussing the possibility of unwanted pregnancies with rape survivors (Table 5). Except for one officer in India, all police respondents were unfamiliar with EC pills (ECP) and their use in preventing unwanted pregnancy. None of the police stations had provisions for stocking ECPs, nor did the police stations have any informational handouts, such as leaflets or brochures, about ECP or reproductive health for rape survivors.

Two police inspectors commented on the lack of RH services for rape survivors as follows:

"We take them (rape survivors) to hospitals anyway; all health facilities are available there. At police stations we don't have any health facilities, we are not doctors."

"Taking (a rape survivor) to hospital is more important for us than to offer medical assistance or guidance."

\begin{tabular}{|lcc|}
\hline \multicolumn{3}{|c|}{$\begin{array}{l}\text { Table 5: Discussion of possibility of } \\
\text { pregnancy (percentage) }\end{array}$} \\
\hline $\begin{array}{l}\text { Possibility of } \\
\text { pregnancy discussed } \\
\text { with survivor }\end{array}$ & $\begin{array}{c}\text { India } \\
(\mathbf{N}=\mathbf{1 7})\end{array}$ & $\begin{array}{c}\text { Bangladesh } \\
\mathbf{( N = 3 8 )}\end{array}$ \\
\hline Always & 0 & 26 \\
Sometimes/Rarely & 0 & 26 \\
Never & 100 & 48 \\
\hline
\end{tabular}

In general, there appeared to be a lack of interest among police officers to provide any $\mathrm{RH}$ information or services to rape survivors within the police station setting. According to police officers, their role was only to take the rape survivor to a health facility after pertinent information about the incident was collected at the station. A few police officers agreed that keeping informational brochures about EC and/or PEP in the police stations would be beneficial, yet none showed interested in pursuing a role as care providers.

Kits for managing rape cases: In both India and Bangladesh, standardized kits for managing rape cases were not available in police stations or familiar to police officers interviewed.

Protocol for managing rape survivors: About one-third of the police respondents in India (6 out of 17) and 89 percent in Bangladesh (27 out of 38) reported following some protocols/ guidelines when managing rape survivors. Our research revealed that written guidelines on the management of rape cases do exist in booklet form, issued by police headquarters and are 
available for internal circulation. Yet official guidelines were not present in any of the police stations visited and most police respondents were unaware of their existence. Four police officers reported following unwritten guidelines that the station had abided by and one police officer reported working by the guidance of his own judgment only.

In Bangladesh, case management was similar. An official guideline on managing rape cases did exist, issued by the Police Headquarters and Ministry of Home Affairs. Yet upon probing police respondents, none of them had the protocol available in their station, and only seven of the 38 police respondents knew that guidelines had been issued. Among police officers who were unfamiliar with the guidelines, 28 believed that rape cases were managed through unwritten guidelines practiced in the police station, and others were unsure about guidelines in general.

Managing juvenile rape cases: In the case of juvenile rape survivors, all police formalities including interrogation and interviews were carried out in the presence of a parent or the survivor's guardian. Consent from the parent/guardian to interview the juvenile survivor was considered an important step by 76 percent (India) and 68 percent (Bangladesh) of the police respondents. In both countries, approximately two-thirds of police personnel reported seeking consent from the juvenile's parent before the interview.

One utensil recommended for the management of juvenile rape cases was pictorial depictions of the questions, to assist the children and youth in answering difficult questions associated with the incident. Unfortunately, over 10 percent of the police respondents in both India and Bangladesh reported never using any visual aids to help the child survivors to answer the questions, and many of them were unaware of these tools in general.

The presence of a parent/guardian during the child survivor's interview may be questionable in certain cases, as he/she may be a suspect. When asked about the presence of suspected parents/guardians during interview and examination, 93 percent of police personnel in India said they would not allow their presence. However in Bangladesh, 74 percent of police respondents felt that the parent/guardian could always be present during the child's interview.

Number of rape cases attended by police personnel: The documented number of rape cases registered in the police station during the last six months was considered confidential information and researchers were not permitted to view this information. However, some police officers did agree to discuss rape cases that they had registered during the last six months. Police officers were asked about the number of rape cases registered in the prior six months, of cases including adult survivors, adolescent survivors and child survivors.

a. Adult women: In India, three of the 11 police respondents indicated attending 2-3 rape cases involving adult women in the last 6 months and one police officer reported attending 7 rape cases in that period. In Bangladesh, of the 9 police respondents, 5 reported attending 1-3 adult rape cases and 3 reported attending 6-10 cases in the 6-month period. Over 90 percent of police respondents felt that the range was generally between 1 and 5 cases every month.

b. Adolescent girls and boys: Of the 12 police respondents in India sharing personal experience, four reported registering 1-2 adolescent rape cases during the last 6 months, and eight reported not registering any. However, one police officer reported registering 10 adolescent boy rape 
cases during this period. This information about rape of adolescent girls and boys was not sought in Bangladesh.

c. Children: Only one police officer in India reported registering a child rape case - he actually reported registering seven child rape cases in the last 6 months, all of them girls. 27 police respondents (of the total 38) in Bangladesh reported attending to child rape cases within the last 6 months; on average two boys and four girls within that period.

\section{Attitude of police personnel towards rape survivors:}

Police personnel's attitude towards rape and rape survivors can have a significant bearing on how rape survivors are treated and how their cases are managed within the police system. In both countries, these attitudes were assessed.

As seen in Table 6, 63 and 74 percent of police personnel perceived rape as a serious medical problem, in India and Bangladesh respectively. Only Indian police personnel (69 percent) felt that rape survivors needed immediate medical attention, while three-fourths of Bangladeshi police felt that rape survivors did not require urgent attention and could wait at the hospital as with all other patients - that their injuries were not fatal.

As the number of rape cases reported increases, there are some suspicions that some reported rapes (and other harassment reports) are being fabricated in order to punish husbands and mothers-in-law who may be demanding dowry from their wife and wife's family (TOI 2008). Most police personnel in India (87 percent) and Bangladesh (68 percent) believed this to be true.

Most police respondents agreed that a husband can rape his wife (India: 94 percent and Bangladesh: 74 percent). Additionally many police officers believed that sex workers could not be raped (66 percent of Bangladeshi police officers and 31 percent in India). One police officer vocalized this impression by saying:

"Sex workers cannot be raped; who wants to rape them?"

Consent for sex is another important issue to be considered when investigating rape cases. To establish rape, it is important to establish that intercourse had taken place without consent from the woman. It can become more complicated if the woman was found to be in inebriated during or after the incident. A majority of police personnel in India (63 percent) and Bangladesh (53 percent) felt that if a woman was drunk it was impossible to say whether or not she had agreed to the sex act.

Women who are raped may also be considered responsible for the attack, whether inebriated or not, if it is thought that they provoked the incident. For example, a common perception is that only "certain types" of women are raped; those women that "move around freely", unescorted and carelessly, women that wear provocative dresses and act in manners that are interpreted to encourage men to want to have sex with them. Bangladeshi police personnel were more likely to hold these views than their Indian counterparts (Table 6). 
Table 6: Attitude of police personnel towards rape survivors in India ( $N=16)$ and Bangladesh ( $\mathrm{N}=38)$ (percentage)

\begin{tabular}{|c|c|c|c|c|}
\hline Statements & Country & Agree & $\begin{array}{c}\text { No } \\
\text { opinion }\end{array}$ & Disagree \\
\hline \multirow{2}{*}{ A woman who is raped is a serious medical problem } & India & 63 & 6 & 31 \\
\hline & Bangladesh & 74 & 21 & 5 \\
\hline \multirow{2}{*}{$\begin{array}{l}\text { A person rarely dies from injuries after rape so they } \\
\text { should wait for their turn for care in hospital }\end{array}$} & India & 31 & 0 & 69 \\
\hline & Bangladesh & 76 & 13 & 11 \\
\hline \multirow{2}{*}{ Raped woman needs care and support for long time } & India & 88 & 0 & 12 \\
\hline & Bangladesh & 68 & 19 & 13 \\
\hline \multirow{2}{*}{ Some women lie about rape to punish men } & India & 87 & 13 & 0 \\
\hline & Bangladesh & 68 & 14 & 18 \\
\hline \multirow{2}{*}{ A husband can rape his wife } & India & 94 & 0 & 6 \\
\hline & Bangladesh & 74 & 2 & 24 \\
\hline \multirow{2}{*}{ Sex workers cannot really be raped } & India & 31 & 6 & 63 \\
\hline & Bangladesh & 66 & 21 & 13 \\
\hline \multirow{2}{*}{$\begin{array}{l}\text { If a woman is drunk, it is impossible to say she did not } \\
\text { agree to sex }\end{array}$} & India & 63 & 6 & 31 \\
\hline & Bangladesh & 53 & 34 & 13 \\
\hline \multirow{2}{*}{$\begin{array}{l}\text { Rape happens because women move around unescorted } \\
\text { and carelessly }\end{array}$} & India & 25 & 6 & 69 \\
\hline & Bangladesh & 53 & 15 & 32 \\
\hline \multirow{2}{*}{$\begin{array}{l}\text { Provocative dress and gestures of women are often the } \\
\text { cause of rape }\end{array}$} & India & 50 & 6 & 44 \\
\hline & Bangladesh & 68 & 18 & 13 \\
\hline \multirow{2}{*}{ Only certain types of woman are raped } & India & 0 & 6 & 94 \\
\hline & Bangladesh & 32 & 10 & 58 \\
\hline \multirow{2}{*}{$\begin{array}{l}\text { Attaching stigma towards rape survivors is also an } \\
\text { offense }\end{array}$} & India & 75 & 6 & 19 \\
\hline & Bangladesh & 47 & 19 & 34 \\
\hline \multirow{2}{*}{ A woman who is raped brings shame on her family } & India & 75 & 0 & 25 \\
\hline & Bangladesh & 60 & 24 & 16 \\
\hline \multirow{2}{*}{$\begin{array}{l}\text { Very delayed punishment or no punishment of } \\
\text { perpetrators encourages rape }\end{array}$} & India & 100 & 0 & 0 \\
\hline & Bangladesh & 63 & 8 & 29 \\
\hline \multirow{2}{*}{ A boy can be sexually abused } & India & 81 & & 19 \\
\hline & Bangladesh & 71 & 5 & 24 \\
\hline \multirow{2}{*}{ Rape leaves obvious physical signs of injury } & India & 56 & 13 & 31 \\
\hline & Bangladesh & 68 & 27 & 5 \\
\hline
\end{tabular}

Additionally, the stigma of shame was associated with having been raped; 75 percent of officers in India and 60 percent in Bangladesh identified this. Surprisingly though, when asked about the stigma associated with rape and rape survivors, 75 and 47 percent of police personnel in India and Bangladesh respectively felt that society should not attach such "stigma" to rape survivors. This inconsistency between what is thought to be appropriate and what is actually practiced in reality is prominent in these potentially controversial situations.

To measure quantitatively the sensitivities of police respondents towards rape survivors, an index was developed using the statements in Table 6 with scores of 1 for responses indicating a lack of sensitivity and 3 for those indicating sensitivity to give a maximum (most sensitive) score of 45 and a minimum (least sensitive) score of 15 . The mean score of an Indian police officer was 34.68 and that of a Bangladeshi officer was 30.28. A T-test $(t=5.113, p<0.0001)$ confirmed that the police personnel in India held significantly more sensitive attitudes towards rape survivors than their counterparts in Bangladesh. 


\section{Health facilities}

A Medico-legal case: Health professionals interviewed in India felt that reporting a rape case to the police was a legal requirement; in Bangladesh, 63 percent acknowledged the importance of reporting the case to the police. Only 22 percent of Bangladeshi health personnel interviewed believed that this police report was a requirement, 16 percent did not recognize it to be a government requirement. In reality, the Bangladeshi legal system requires reporting of rape cases to the police first. In those cases when rape survivors come to the hospital before the police station, they are usually sent to the police station before receiving care.

Counseling and emergency treatment is often provided to rape survivors before they are sent to the police station. In India, 58 percent of health practitioners reported providing some counseling and emergency treatment to rape survivors before calling the police to register the rape case. However, 25 percent of the Indian providers and 69 percent of Bangladeshi providers sent rape survivors to the police immediately if the case was unreported, before providing any health services to the patient.

Additional to filing mandatory reports with the police, there are additional formalities to be completed within the health system. Medico-legal case (MLC) registration must be completed and patient consent must be obtained before the medical examination can take place. In Bangladesh, a requisition form must also be collected from police before patient examination can begin. Proof of a patient's identification and verification of a female attendant's availability for examination are two additional requirements that should be fulfilled before examination. It was estimated that these steps take approximately 30 minutes to complete, delaying medical examination while they are processed. Unfortunately, most health service providers were unaware of all of the process formalities - for example, obtaining consent from the survivor was only mentioned as a formality by 50 percent of Indian respondents and 41 percent in Bangladesh.

Medical examinations: The medical examination includes a gynecological examination and collection of samples for forensic tests. The study revealed that both in India and Bangladesh (83 and 94 percent respectively) "all" rape survivors are subjected to the full medico-legal examinations (gynecologic and samples for forensics) irrespective of whether they choose to pursue a case against the perpetrator. Discussions with the doctors revealed the following details about the medico-legal examinations. 


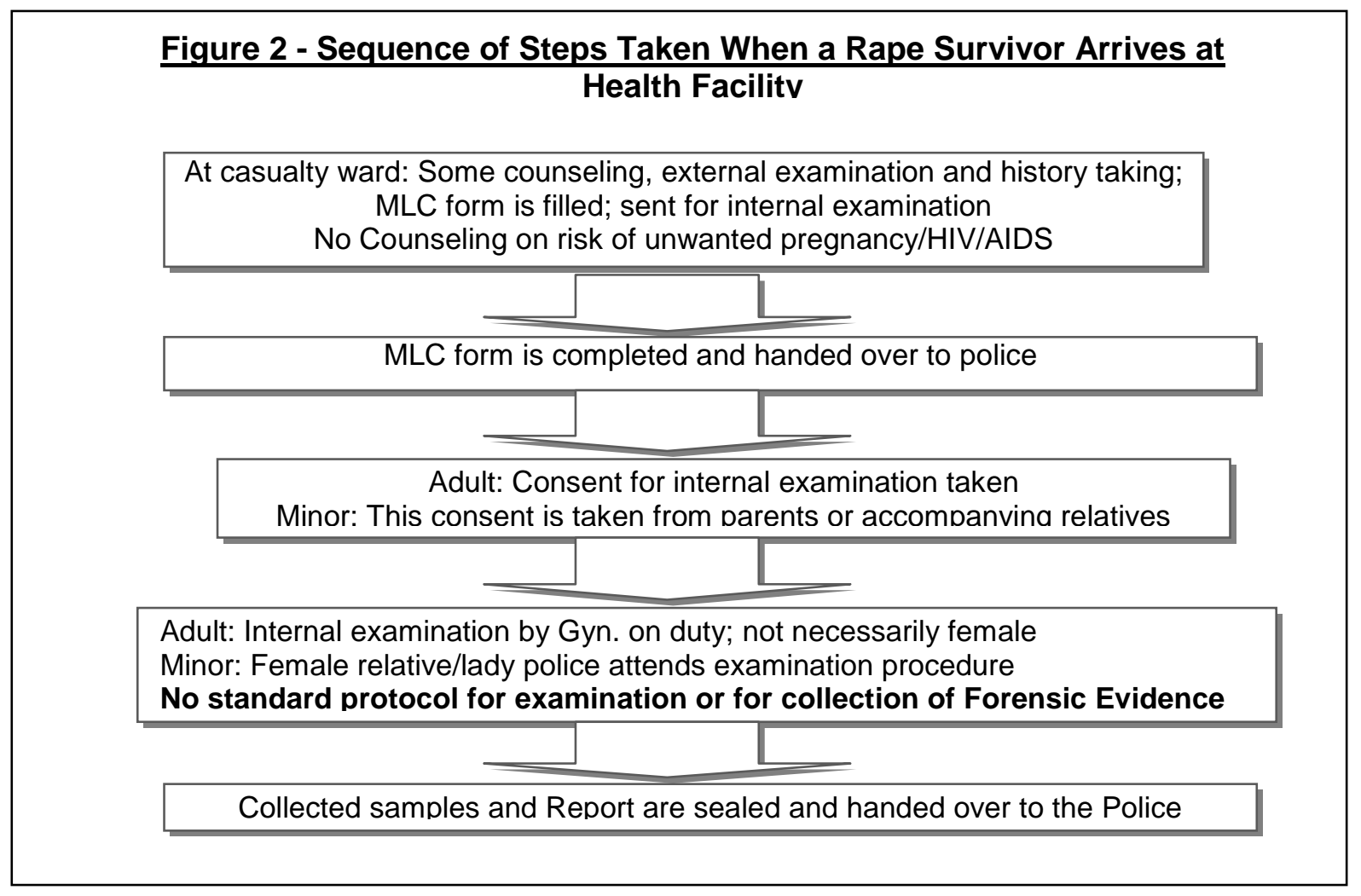

a. Waiting time before the examination: While waiting for the examination, a rape survivor in India generally waits in the corridor or outside the examination room. In Bangladesh, rape survivors wait in a private room most of the time. During the wait, the rape survivor is counseled, provided an explanation of the upcoming procedure and asked to give consent for the examination. In the case of minors and juveniles, consent was obtained from accompanying relative or parents before the examination takes place.

b. Examining doctor: Rape survivors are generally examined in the gynecology department or by a gynecologist in the emergency/casualty ward. When the patient is a juvenile, a pediatrician is also called in to examine the case. The examining doctor is not necessarily always a female, as some doctors interviewed reported:

"There is no such mandate to have a female doctor to examine a rape survivor. If there is a male gynecologist on duty, he does the examination (of the rape survivor)." - HOD of Obstetrics and Gynecology Department.

"There are male gynecologists in our department and they do the examination when such cases come and if at that time they are on duty" - A female gynecologist.

c. Accompanying person: During the examination of adult rape survivors in India, female family members were allowed to be present in the examination room if desired by the patient. In Bangladesh, others were not allowed to accompany the patient, except in the case of minors. The majority of the doctors interviewed in India ( 83 percent) and Bangladesh (46 percent) reported allowing a family member into the room during examination. 
d. Examination procedures: All rape cases were required to undergo an internal examination. Yet, there are a number of differences in procedures for adult and minor rape cases. The doctors interviewed reported conducting per vaginal (PV) examinations on married women, to identify possible cuts or bruises signifying forced penetration. In the case of virgins and juveniles, PV examinations were not conducted and only exterior wounds (such as bleeding, wounds and bruises) were examined. In fact, doctors from both study countries mentioned the difficulties of conducting internal examinations on survivors less than 10 years old, the potential need for anesthesia and the multiple surgeries that may have been needed for full recovery. Below is an account of how one doctor manages these cases:

"When in doubt as to what to do in such cases, we consult our seniors. This often happens during night shifts, when the senior doctors are not around. Sometimes they also have to come to supervise and guide us".

e. Collection of forensic evidence: In both countries, survivors undress for medical examination, mostly on their own. 83 percent of the health practitioners interviewed in India reported that the general practice was to collect survivor's clothes. Other biological samples for forensic examinations were also collected during the medical examination. Table 7 describes the various items that are routinely collected during examination of rape survivors and which are then sent for forensic tests.

\section{Table 7: Samples collected during examination of rape survivors for forensic tests (percentage)}

\begin{tabular}{|l|c|c|c|c|c|c|c|}
\hline $\begin{array}{l}\text { Materials collected } \\
\text { during medical } \\
\text { examination }\end{array}$ & \multicolumn{4}{|c|}{ India (N=12) } & \multicolumn{3}{c|}{ Bangladesh (N=32) } \\
\cline { 2 - 8 } & $\begin{array}{c}\text { Always/ } \\
\text { mostly }\end{array}$ & $\begin{array}{c}\text { Some } \\
\text { times }\end{array}$ & $\begin{array}{c}\text { Rarely/ } \\
\text { never }\end{array}$ & $\begin{array}{c}\text { Do not } \\
\text { know }\end{array}$ & $\begin{array}{c}\text { Always/ } \\
\text { mostly }\end{array}$ & $\begin{array}{c}\text { Some } \\
\text { times }\end{array}$ & $\begin{array}{c}\text { Rarely/ } \\
\text { never }\end{array}$ \\
\hline Panties & 67 & 8 & 0 & 25 & 0 & 22 & 78 \\
Sanitary napkins & 15 & 15 & 17 & 33 & 3 & 6 & 91 \\
External anal swab & 17 & 15 & 33 & 25 & 0 & 53 & 47 \\
Tampons & 33 & 17 & 25 & 25 & 0 & 6 & 94 \\
External genital swab & 75 & 0 & 0 & 25 & 53 & 41 & 6 \\
Deep vaginal swab & 83 & 0 & 0 & 17 & 97 & 0 & 3 \\
Cervical swab & 42 & 0 & 33 & 25 & 0 & 38 & 62 \\
\hline
\end{tabular}

As the table shows, there was a wide variation in materials collected for forensic examinations. In India, panties, sanitary napkins, external genital swab, and deep genital swab were reported to be collected more than 50 percent of the time. Very few doctors in India reported the collection or observation of other potential items of evidence such as bloodstains, semen stains, and hair and nail clipping. In Bangladesh, doctors reported the collection of only three material evidences - external genital swab, deep vaginal swab and cervical swab on a regular basis - and all others were only sometimes, rarely or never collected.

After their collection, samples were handled in a number of ways - either handed over to the police, taken to designated forensic laboratories or left in custody of facility manager. Methods varied by country and health care facility. 
Concerns raised by survivors of sexual assault: When asking doctors about patients' concerns and worries associated with the rape incident, it was clear that very little information was sought by rape survivors. 50 percent of doctors reported that patients asked questions about pregnancy, and 75 percent said that patients enquired about STI or HIV/AIDS. Only a few doctors reported providing unprompted information about either HIV or STIs. Many survivors may be under shock and/or too uncomfortable to ask for information about these topics and so if doctors are not providing information or services on their own volition, many of these patients proceed without it.

"They don't ask for many of the services which you are asking (meaning ECP and PEP). We don't have all these services also. At that time they are so much traumatized to even think of anything else."

A percentage of Bangladeshi doctors reported that rape survivors often enquired about the possibility of pregnancy ( 44 percent), possible internal injuries (59 percent) and the social stigma associated with rape (59 percent).

Reproductive health facilities for rape survivors: The provision of RH services to rape survivors is still not a well-developed concept in India and Bangladesh. There is no uniform code of conduct or protocol for managing the health and safety of rape cases in public health facilities. This disparity is well reflected in some of the queries investigated during data collection and analyzed below, and is also displayed in Figure 2 above.

a. Sexually Transmitted Diseases: Survivors of sexual violence are usually considered at increased risk of acquiring STIs, making STI prophylaxis services pertinent components of the services available to rape survivors. Health personnel interviewed had a good frame of knowledge about WHO's STI treatment regimen. Additionally, 58 percent of the providers in India and 50 percent in Bangladesh believed that every survivor of sexual violence should receive STI treatment. Unfortunately, when evaluating the STI treatment provided to the rape survivors, the picture is different. Table 8 describes the physician's impressions of STI treatment provision. In Bangladesh, 94 percent of the doctors believed that most rape survivors do not receive any STI protection services.

\begin{tabular}{|c|c|c|}
\hline $\begin{array}{l}\text { Is STI treatment given } \\
\text { to rape survivors? }\end{array}$ & $\begin{array}{c}\text { India } \\
(\mathrm{N}=12)\end{array}$ & $\begin{array}{c}\text { Bangladesh } \\
(\mathrm{N}=32)\end{array}$ \\
\hline Yes, to all & 42 & 6 \\
\hline Mostly not given & 33 & 94 \\
\hline Do not know & 25 & 0 \\
\hline
\end{tabular}

b. Anti-emetics (anti-nausea medications): The majority of health personnel in India (67 percent) and Bangladesh (94 percent) did not offer anti-emetics to rape survivors at their facilities. When these medications were administered, Perinorm was commonly prescribed in India, and Stemetil and Domiperidone in Bangladesh.

c. HIV prophylaxis: Nine questions were formulated to assess HIV prevention (including prophylaxis, VCT and referrals) services available to rape survivors. 
PEP (post exposure prophylaxis) is an important drug regimen for the prevention of HIV transmission. The HIV preventative services offered to rape survivors are presented in Table 9. Twenty seven percent of doctors in India said that they advise rape survivors to take PEP if the timing is appropriate. However, only nine percent of doctors demonstrated correct knowledge about the PEP regime, questioning the validity of their provision. About 55 percent of doctors reported that HIV testing and voluntary counseling and testing (VCT) was available to rape survivors - 27 percent of doctors reported offering VCT services; 55 percent reported referring patients to VCT center.

In Bangladesh HIV preventative services for rape survivors was practically non-

\begin{tabular}{|c|c|c|}
\hline & $\begin{array}{c}\text { India } \\
(\mathrm{N}=11)\end{array}$ & $\begin{array}{c}\text { Bangladesh } \\
(\mathrm{N}=32)\end{array}$ \\
\hline $\begin{array}{l}\text { Advice about PEP (if patient } \\
\text { brought within } 72 \text { hours) }\end{array}$ & 27 & 0 \\
\hline $\begin{array}{l}\text { Correct answer for PEP } \\
\text { regimen }\end{array}$ & 9 & 19 \\
\hline $\begin{array}{l}\text { HIV testing carried out for } \\
\text { rape survivors }\end{array}$ & 55 & 6 \\
\hline Offer VCT for Rape survivors & 27 & 3 \\
\hline Referral for VCT & 55 & 0 \\
\hline
\end{tabular}
existent. Although 19 percent of the doctors had correct knowledge of use of the PEP regime for infection prevention, none of the doctors were offering or advising PEP to rape survivors. Only six percent were carrying out HIV tests in their clinics and 3 percent were referring patients to VCT clinics.

\section{d. Emergency contraception (EC):}

Two-thirds of doctors in India and 16 percent in Bangladesh reported offering EC to rape survivors (Table 10). Most facilities, however, did not have ECP available in stock. In most cases, when a survivor is advised to receive ECPs or asked about ECPs, they were sent to purchase it on their own from the market.

\begin{tabular}{|lcc|}
\hline \multicolumn{2}{|c|}{$\begin{array}{c}\text { Table 10: Provision of emergency contraception to } \\
\text { rape survivors (percentage) }\end{array}$} \\
\hline \multicolumn{2}{|c|}{$\begin{array}{c}\text { India } \\
\text { (N=12) }\end{array}$} & $\begin{array}{c}\text { Bangladesh } \\
\text { (N=32) }\end{array}$ \\
\hline $\begin{array}{l}\text { Rape survivors offered emergency } \\
\text { contraception }\end{array}$ & 67 & 16 \\
Stock ECP at facility & 25 & 10 \\
& & \\
\hline Pregnancy test conducted for rape & & \\
survivors & 33 & 3 \\
1. Always/mostly & 25 & 6 \\
2. Sometimes/rarely & 17 & 88 \\
3. Never & 25 & 3 \\
4. Do not know & & \\
\hline
\end{tabular}

Counseling for rape survivors: Counseling services for rape survivors were not well established in India and Bangladesh. Only 8 percent of the facilities reviewed in India and 22 percent in Bangladesh had trained counselors who were providing counseling services to rape survivors. In facilities without trained counselors, the nurses or doctors offered the counseling, although they may have actually been untrained in counseling. Doctors and nurses reported also referring rape survivors to other facilities for counseling (Table 11). 


\begin{tabular}{|c|c|c|}
\hline \multicolumn{3}{|c|}{$\begin{array}{l}\text { Table 11: Counseling services for rap } \\
\text { as reported by doctors (percentage) }\end{array}$} \\
\hline & $\begin{array}{c}\text { India } \\
(\mathrm{N}=12)\end{array}$ & $\begin{array}{c}\text { Bangladesh } \\
(\mathrm{N}=32)\end{array}$ \\
\hline Counseling offered to all survivors & 17 & 31 \\
\hline \multicolumn{3}{|l|}{ Counseling facilities: } \\
\hline Counselor at facility & 8 & 22 \\
\hline Medical staff trained in counseling & 8 & 3 \\
\hline Referral for counseling & 42 & 72 \\
\hline No facility & 42 & 3 \\
\hline
\end{tabular}

A senior doctor at a Delhi hospital explained his facility's counseling situation with the following quote:

"We don't have a counselor here at this facility; if need arises we refer the case to psychiatric department. But there is no follow-up, there is no second visit. They only come once for internal examination".

In Bangladesh, counseling is mostly provided by One Stop Crisis Centre (OCC), an organization established to provide specialized care and support to rape survivors. However, there are only a few of these facilities throughout the country, attached to medical hospitals in major cities (see Box 3).

Counseling sessions provided to rape survivors last between 10-30 minutes according to health practitioners in India; in Bangladesh sessions were reported to be between 1 and 2 hours. Unfortunately, legal advice was not readily available to patients in health facilities (reported by $82 \%$ medical respondents in India and 69\% in Bangladesh). However, the OCCs are available in Bangladesh, and many of these counseling opportunities are available within these service centers.

Post rape kit: Post-rape kits that include products such as sanitation products, clean clothes and objects of comfort, were familiar to some interviewed doctors. However, no facilities in India and Bangladesh had any post-rape kits available to rape survivors.

Protocol/management guidelines: Standard protocols for service provision to rape survivors were not available in facilities reviewed in India or Bangladesh. All doctors interviewed reported conducting services according to the patient's needs and not following any set guidelines or recommendations established by the facility. Additionally, some doctors did not feel a need for a standardized protocol:

"There is no protocol, we don't need any protocol. Where is the need? We are taught all these. So we know" - A senior resident doctor

One hospital in Delhi the Director of Gynecology was assisting in the drafting of guidelines for a standard protocol for post-rape patient management.

Training for provision of services to rape survivors: In general, the medical professionals interviewed had not received any training in providing specialized care to rape survivors, although many respondents were aware of specialized trainings. The majority, however, (58\% in (India and $88 \%$ in Bangladesh) showed interest in and willingness to receiving training in the management of rape survivors. 


\section{Box 3: Care and Support for rape survivors: One stop crisis centers (OCC) in Bangladesh}

One Stop Crisis Center (OCC) is a specialized 'one stop' facility in Bangladesh, where all required services for rape survivors are provided. This provides health care, police assistance, social services, legal assistance, psychological counseling \& shelter services.

In Bangladesh, OCCs have been established in all six country divisions. OCCs were established in Dhaka and Rajshahi Medical College Hospitals, during the pilot phase of the project, and four new OCCs were put in place in Sylhet, Chittagong, Khulna and Barisal Medical College Hospitals, initiating in June 2006.

OCC activities: The One-Stop Crisis Centers accepts patients of a variety of conditions and situations. Sexual assault survivors, burn survivors, and those who've experienced physical assault (including domestic violence). The OCC provides medical treatment, security and counseling by police at the center, and also provides legal counseling and support from the BNWLA. Medico-legal examinations may be conducted at the OCC if deemed necessary and appropriate for the incident. Psychological counseling is available as well. The Department of Social Service Office provides social welfare services to patients, and temporary shelter is also available at a partner organization, the BNWLA. Additionally, the OCCs have hotline services for patients in need of counseling or information; this service also provides academic activities and research training for providers.

How it works: Survivors of sexual assault are admitted to OCC either through the emergency department or from other referrals. The most important feature of these centers is that all services are available on site, medical and legal care is brought to the center, and patients have access to any service that they may need associated with the management of their incident. Acute medical issues endangering the patient (i.e. injury, fracture, perineal tear) are treated before referral to OCC. The OCCs are equipped with 8 beds and care is provided by the same doctors that work within the medical facilities, utilizing referrals to specialized departments (i.e. gynecology, orthopedics, pediatrics) if necessary. The medico-legal examination is conducted by the Department of Forensic Medicine, legal assistance is also available at the OCCs, and police are posted at each centre to answer questions and/or pursue criminal investigation. Psychological counseling is available for those patients requiring mental health services, and social services (including shelter and rehabilitation) are also available within the centre.

OCC personnel: One Coordinator and three staff members are posted at OCC. OCCs are usually located adjacent to medical center emergency departments and function on a 24 hour schedule, all days of the week. Doctors posted to the OCC work 8am to 2am, and outside of these hours, the emergency officer admits and treats patients.

Attitudes towards rape survivors: Attitudes of doctors and other medical professionals towards rape and rape survivors were captured in a questionnaire and responses are represented in Table 12. The majority of medical staff in India (75 percent) and Bangladesh (91 percent) considered rape a serious medical problem and child rape as an emergency medical situation (100 percent in both countries). Yet, doctors in Bangladesh did not feel the need to provide priority or expedited care to rape cases, when compared to other medical conditions, and 66 percent of Bangladeshi doctors believed that rape survivors should wait, together with all other patients, because their injuries are usually not fatal. In India, the majority believed rape survivors should be prioritized in care provision. 
Table 12: Attitude of health care providers towards rape survivors in India and Bangladesh

\begin{tabular}{|l|l|c|c|c|}
\hline Statements & Country & Agree & $\begin{array}{c}\text { No } \\
\text { opinion }\end{array}$ & Disagree \\
\hline A woman who is raped is a serious medical problem & India & 75 & 0 & 25 \\
& Bangladesh & 91 & 0 & 9 \\
\hline A child who has been raped is an emergency medical & India & 100 & 0 & 0 \\
case & Bangladesh & 100 & 0 & 0 \\
\hline A person rarely dies from injuries after rape, so they & India & 25 & 0 & 75 \\
should wait for their turn for care in hospital & Bangladesh & 66 & 0 & 34 \\
\hline \multirow{2}{*}{ Some women lie about rape to punish men } & India & 100 & 0 & 0 \\
& Bangladesh & 91 & 3 & 6 \\
\hline \multirow{2}{*}{ Rape is more serious for someone who is a virgin } & India & 58 & 0 & 42 \\
& Bangladesh & 75 & 0 & 25 \\
\hline Sex workers cannot really be raped & India & 0 & 0 & 100 \\
& Bangladesh & 13 & 3 & 84 \\
\hline If a woman is drunk, it is impossible to say she did not & India & 42 & 16 & 42 \\
agree to sex & Bangladesh & 63 & 13 & 25 \\
\hline Provocative dress and gestures of women are often the & India & 42 & 8 & 50 \\
cause of rape & Bangladesh & 84 & 0 & 16 \\
\hline It is disgraceful for women to bring rape cases to the & India & 25 & 8 & 67 \\
court & Bangladesh & 81 & 0 & 19 \\
\hline \multirow{2}{*}{ A woman who is raped brings shame on her family } & India & 25 & 8 & 67 \\
& Bangladesh & 81 & 0 & 19 \\
\hline Rape leaves obvious signs of injury & India & 42 & 8 & 50 \\
& Bangladesh & 22 & 0 & 78 \\
\hline Only certain types of woman are raped & India & 0 & 8 & 92 \\
& Bangladesh & 4 & 0 & 88 \\
\hline
\end{tabular}

Similar to police officers, many medical professionals believed that rape cases may be fabricated in efforts to punish husbands and/or mothers-in-law. But conversely to the police, doctors were not so biased against sex workers and supported care and services for all women. Doctors did agree with the police in feeling that the choice of clothing and/or a woman's "inappropriate conduct" may make her more vulnerable to sexual assault. Bangladeshi doctors also reported believing that rape brings "shame" to a woman's family and her pursuing action in court is further disgracing to her family.

Virginity is important in South Asian countries and rape of a virgin is considered to be a more serious incident than rape of a married woman. The health staff supported this attitude, yet many doctors vocalized the gravity of rape for all patients, independent of marital status.

As for police officers, a sensitivity index was developed to assess and compare their level of sensitivity towards rape and rape survivors using the responses to the 12 questions described in Table 12, giving a score between 12 and 36. On an average, Indian doctors scored 27.6 and Bangladeshi doctors scored 22.8; a T-test suggests that this difference is statistically significant $(\mathrm{t}=4.521 \mathrm{p}<0.0001)$. 


\section{Situation analysis tool development}

One objective of this study was to develop sensitive and practical tools that could be used to conduct large-scale situation analysis studies of the RH services available to rape survivors at their first point of contact in this region. Accordingly, two interview schedules were developed, one for police personnel and another for health care providers, to assess these individual situations in terms of managing rape survivors.

Initial pre-testing of tools took place in India and Bangladesh, and tools were then modified and improved. A selected number of police stations and health facilities were included in the situation analysis pilot study and as a result, a few changes were made to improve the flow and wording of questions, and additional questions were added.

The results of this pilot study in India and Bangladesh demonstrate that the RH services available to rape survivors at the first point of contact, particularly within police stations, are lacking. With this scarcity of services, many of the items remained unanswered. The final tools are presented in Appendices A and B. To get a better insight, particularly as a large number of questions remained "not applicable" and unanswered, a certain amount of in-depth probing would enhance the quality of data collected and so is recommended when training researchers in use of these tools.

\section{LESSONS LEARNED AND RECOMMENDATIONS}

This pilot study provided a broad picture of the reproductive health services available to rape survivors at their first point of contact. However, the study only included a small number of facilities and so cannot provide findings that can be considered descriptive of the overall situation in India or Bangladesh. However, the results do indicate directions that could help in the planning and undertaking of larger situation analyses of rape case management. The salient points emerging from this research are presented below.

\section{Waiting time for services}

Rape survivors have legal and health requirements that require timely assistance. For instance, PEP and ECP are most effective when given within 72 hours of the exposure and forensic tests yield best results when samples are collected within 24 hours of the assault. This urgency should motivate immediate attention and care; however the analysis revealed that various situations and medico-legal requirements delay medical examination and treatment of rape survivors. These delays may lead to significant RH risks and may also weaken the survivor's legal case.

Rape in India and Bangladesh is treated as a medico-legal case, requiring police involvement and legal registration of the case. Accordingly, legal registration and a police report must be collected before medical attention is provided, many times inducing additional delay, especially when rape survivors seek care from a health facility before reporting incident to the police. Waiting times are inevitably increased, as paper work and administrative duties are burdensome and patients must often wait for lady police officers (LPOs) to come to the police station. These delays compromise the physical and psychological health of rape survivors within this system. 


\section{Situation at police stations}

Lack of standard protocol: Most police stations visited in India and Bangladesh have a standard protocol to attend to the formalities associated with a rape case. Yet, copies of guidelines were not available and police officers were unfamiliar with the procedures.

Training: Police personnel received some training on the appropriate management of rape cases within their pre-service curriculum when joining the police force. However, most of them did not receive any additional training on this subject and did not express much interest to do so.

Counseling skills: Police officers and LPOs in both Bangladesh and India did not participate in any training on counseling rape survivors. Despite this, some officers do provide counseling to rape survivors. In Bangladesh, a common practice is to provide sedatives to uncomfortable rape survivors before interviewing them.

RH information and services: RH services, such as the provision of ECP services, STI prophylaxis, HIV testing or PEP counseling, were non-existent in police stations. Most police officers were unfamiliar with these services and believed that their duties concerning the survivor's health ended with taking the survivor to medical facilities. Only a few police officers showed interest in learning more about ECP and PEP; a few were also interested in providing $\mathrm{RH}$ information to rape survivors at the police station.

Privacy: Privacy for rape survivors was compromised in India, with waiting areas only available in common areas. In Bangladesh, the level of privacy available to rape survivors was good, with private rooms available for survivors during waiting and interrogation periods.

Sensitiveness of the police officers: Police officers demonstrated excessive insensitivities towards rape survivors, with prejudices and stereotypes prevalent in their interpretations. These thoughts were significantly more prominent among police officers in Bangladesh than in India.

\section{Situation at health facilities}

Standardized protocol for managing rape survivors: No standard written protocols or guidelines exist for managing rape survivors in health facilities in either country. Moreover, some doctors do not feel there is a need for development of such protocols.

Standardized protocol for collecting forensic evidences: No standard protocol was available in any of the facility to collect forensic evidences. As a result, forensic evidences collected during examination varied widely from one facility to other. Fewer items of forensic evidences were collected in Bangladesh than in India.

Availability of post-rape care kits: Post-rape care kits were unfamiliar to interviewed professionals and unavailable in the respective facilities.

On the job training and counseling skills: Doctors did not receive special training on the management of rape survivors. Similarly very few health facilities had a trained counselor available to counsel rape survivors. Indian hospitals appeared relatively better equipped than Bangladeshi hospitals, although the One Crisis Centers available in Bangladesh showed significant promise in care provision for rape survivors. 
Provision of EC information and services: EC was not available at medical facilities in Bangladesh. EC was available in India, yet distribution had not been institutionalized and only a few hospitals in both countries were actively stocking the contraception method.

Provision of STI information and services: Doctors in both countries had a good understanding of STI treatment, yet only a few health facilities were providing STI/HIV prevention in India and STI information provision was almost non-existent in Bangladesh.

Provision of PEP information and services: Most providers lacked knowledge of PEP and this area warrants significant improvements.

Sensitiveness of the doctors towards rape survivor: There were noteworthy levels of insensitiveness among the doctors towards rape survivors and rape incidents in both India and Bangladesh. Changes in this realm should be pursued.

\section{Tools for the situation analysis}

The two tools developed and pilot tested in this study are comprehensive and can be used in similar situation analyses of the first point of contact of rape survivors in other settings. However, as the facilities visited had not developed post-rape care services and the provision of services was so compromised, many questions went unanswered. Because of this, it is strongly recommended that in-depth probing is added to the questionnaire that could collect greater detail.

\section{Study limitations}

Rape is a sensitive issue and any data collection on the subject demands considerable time and preparatory work. Arranging appointments and obtaining permission from supervisors to interview police officers and doctors added significant challenges and delays to the study.

The results from this pilot study should be interpreted with caution as the total number of police medical professionals interviewed is quite small. However, the experiences and findings are noteworthy and the pilot study findings provide important lead-ins for further full-scale situation analyses in this area of interest. 


\section{RECOMMENDATIONS}

- Steps should be taken to reduce waiting times at police stations and health facilities by making rape cases a priority.

- Both police and doctors need on-the-job orientation on how to properly manage rape cases, including emphasis on their reproductive health needs, sensitivities and service requirements.

- Protocols for managing rape survivors and collecting forensic evidences should be standardized, available and strictly implemented in police and health facilities.

- Trained counselors and other professionals with counseling skills are lacking in both police and health facilities. Counseling should be emphasized in the care of rape survivors.

- As part of a comprehensive care and support strategy for rape survivors, police officers should become familiar with medical and $\mathrm{RH}$ needs of rape survivors. Care and services for some of these needs could be made available at police stations, such as EC information and provision.

- Before major changes are pursued within these two systems, a situational analysis covering a larger number of health facilities and police stations would provide more valid information to guide such development of a more comprehensive system of post-rape care.

\section{DISSEMINATION}

The key findings from this situation analysis, and the program recommendations and actions, were presented in a dissemination meeting organized by FRONTIERS on 'Challenges in Reproductive Health: Lessons Learned from FRONTIERS Program "' in Ahmadabad, India on May 15, 2008. The participants included key program managers, state level officials and representatives from national and international agencies. During the meeting, prevailing gaps in the health and police system and the need to develop a comprehensive care package for sexual violence survivors within the public system were two recommendations highlighted by the speaker and in the discussion. 


\section{REFERENCES}

Badruddoza, A.S.M. 2002. "Plight of Women in Bangladesh" PUCL Bulletin, December 2002. http://www.pucl.org/Topics/International/2002/bangla-women.htm

Christofides Nicola, D Muirhead, R K Jewkes, L Penn-Kekanna, D N Conco 2005. "Women's experiences of and preferences for services after rape in South Africa: interview study" British Medical Journal, doi:10.1136/bmj.38664.482060.55 (published 5 December 2005)

Coalition for the International Criminal Court 2007. Odhikar Press Release on Violence against Women in Bangladesh on the Occasion of International Women's Day 2007, Dated: 08, March 2007

International Institute of Population Sciences (IIPS) and Macro International 2007. National Family Health Surveys (NFHS-3), 2005-2006: India, Mumbai IIPS.

Keesbury, J., Skibiak, J. \& M. Zama. 2006. "Reducing unwanted pregnancy among survivors of sexual assault: New windows of opportunity for Emergency Contraception. Draft paper: Population Council.

Khan, M.E. and Aditi Aeron 2006. "Prevalence, Nature and Determinants of Violence against Women in Bangladesh”, The Journal of Family Welfare, F.P.A India, Vol. 52, Special Issue 2006.

Khan, M.E. and Aditi Aeron. 2006. "Situation of GBV in Asia" Oral presentation at SGBV workshop in Zambia. 16-19 October

Khan, M.E., John W. Townsend, Ranjana Sinha and Seema Lakhanpal 2003. "Sexual Violence Within Marriage: A case study of rural Uttar Pradesh, India, International Quarterly of Community Health Education. Volume 21, Number 2.

Koenig, Michael A., Rob Stephenson, Saifuddin Ahmed, Shireen J. Jejeebhoy, and Jacquelyn Campbell 2006. "Individual and Contextual Determinants of Domestic Violence in North India”, American Journal of Public Health, 2006 January; 96(1): 132-138.

Liverpool VCT \& Care Kenya 2005. "Comprehensive Post-Rape care Services in Resource-poor Settings: Lessons learnt from Kenya”, Policy Brings for Health Sector Reform, LVCT, Number 6 September 2005.

National Crime Record Bureau. 2006. "Crime in India - 2005”. NCRB, Ministry of Home Affairs, GOI, New Delhi.

National Crime Record Bureau. 2007. "Crime in India - 2006”. NCRB, Ministry of Home Affairs, GOI, New Delhi.

National Rural Health Mission (NRHM) 2006. Implementation Guide on RCH II Adolescent Reproductive Sexual Health: For state and district program managers. IEC Division, Ministry of Health and Family Welfare, Government of India. 
Pitre, Amita. 2005. "Ethical Considerations regarding Medico-legal services in cases of Sexual Assault". Paper presented at the $1^{\text {st }}$ national Bioethics Conference, $25^{\text {th }}$ to $27^{\text {th }}$ November 2005

Pitre, Amita. 2006. "Care for Survivors of Sexual Assault”. Indian Journal of Medical Ethics. Volume III, No. 3 July-September 2006.

Population Council 2007. Draft copy, Review of Literature. FRONTIERS/Population Council.

Population Council 2008. Sexual and Gender Based Violence in Africa: Key Issuesfor Programming. Population Council Inc.

Martin S.L., S. Young, D.L Billings 2007. Assessment Instruments Used To Study HealthcareBased Interventions for Women Who Have Experienced Sexual Violence, IPAS, Sexual Violence Research Initiative (SVRI).

Times News Network 2006. "Women seek safety against cops”. Times News Network. 9 March 2006.

Times of India 2008. "Government to Review Anti-Dowry Law”. Times of India, Delhi. 2 September 2008.

U.S. Department of State 2005. "Bangladesh Country Reports on Human Rights Practices 2005", released by the Bureau of Democracy, Human Rights, and Labor, March 8, 2006.

Wax, Emily 2008. “In India, New Opportunities for Women Draw Anger and Abuse from Men”, Washington Post Foreign Service, Monday, August 21, 2008; ALL; New Delhi.

World Health Organization (WHO) 2002. Adolescent Friendly Health Services: An Agenda for Change. WHO, Geneva.

World Health Organization. 2002. World Report in Violence and Health. Chapter 6. WHO, Geneva.

World Health Organization. 2003. “Guidelines for Medico-legal Care for Sexual Violence Survivors" WHO, Geneva

World Health Organization 2004. "Preventing Violence: A guide to implementing the recommendations of the World report on violence and health", WHO, Geneva.

World Health Organization. 2005. "Sexually Transmitted and other Reproductive Tract Infections: A guide to essential practice". WHO/Geneva.

World Health Organization 2005. WHO Multi-country Study on Women's Health and Domestic Violence against Women: Initial results on prevalence, health outcomes and women's responses. WHO, Geneva. 


\section{Appendix A: Situation Analysis of First Point of Contact for Survivors of Sexual Assault}

\section{Health Providers}

Facility Identification

\begin{tabular}{|c|c|c|c|c|}
\hline $\begin{array}{l}\text { Q. } \\
\text { No. }\end{array}$ & Questions and Filters & Coding Categories & & Codes \\
\hline 1 & Schedule Serial Number & & & \\
\hline 2 & Country & $\begin{array}{l}\text { India } \\
\text { Bangladesh }\end{array}$ & $\begin{array}{l}1 \\
2\end{array}$ & \\
\hline 3 & City & $\begin{array}{l}\text { Delhi } \\
\text { Vadodara } \\
\text { Lucknow } \\
\text { Bangalore } \\
\text { Dhaka } \\
\text { Chittagong } \\
\text { Khulna } \\
\text { Tangail }\end{array}$ & $\begin{array}{l}1 \\
2 \\
3 \\
4 \\
5 \\
6 \\
7 \\
8\end{array}$ & \\
\hline 4 & $\begin{array}{l}\text { Name of the facility } \\
\text { INS: Give name }\end{array}$ & & & \\
\hline 5 & Date of interview & $\frac{1}{\mathrm{DD} / \mathrm{MM} / \mathrm{YYYY}}$ & & \\
\hline 6 & Name of the Interviewer & 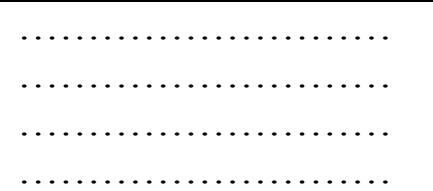 & & _ \\
\hline 7 & Interview completed in & 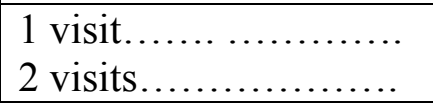 & & \\
\hline
\end{tabular}




\section{Section 1: Characteristics of the service provider}

\begin{tabular}{|c|c|c|c|c|}
\hline & Questions and filters & Coding Categories & & $\begin{array}{l}\text { Skip To/ } \\
\text { Codes }\end{array}$ \\
\hline 101 & What is your position at the health facility? & $\begin{array}{l}\text { Psychiatrist } \\
\text { Gynecologist } \\
\text { Resident Medical Officer } \\
\text { Pediatrician } \\
\text { Trained staff for rape case } \\
\text { Counselor } \\
\text { Nurse } \\
\text { Forensic Doctor } \\
\text { Other (specify) }\end{array}$ & $\begin{array}{c}01 \\
02 \\
03 \\
04 \\
05 \\
06 \\
10 \\
11 \\
77\end{array}$ & \\
\hline 102 & Sex of the Respondent? (observe) & $\begin{array}{l}\text { Male } \\
\text { Female }\end{array}$ & $\begin{array}{l}1 \\
2 \\
\end{array}$ & \\
\hline 103 & Current age of the respondent in completed years? & Years & & \\
\hline 104 & What is your highest professional qualification? & $\begin{array}{l}\text { MS/MD } \\
\text { MBBS } \\
\text { M.Sc/M.A } \\
\text { Specialization in Psychology. } \\
\text { Nursing. } \\
\text { Other }\end{array}$ & $\begin{array}{l}1 \\
2 \\
3 \\
4 \\
5 \\
7\end{array}$ & \\
\hline 105 & How long have you been in service at this facility? & Months & & \\
\hline 106 & $\begin{array}{l}\text { How long have you been in Medical profession in } \\
\text { total? }\end{array}$ & Months & & \\
\hline
\end{tabular}




\section{Section 2: Service Provision}

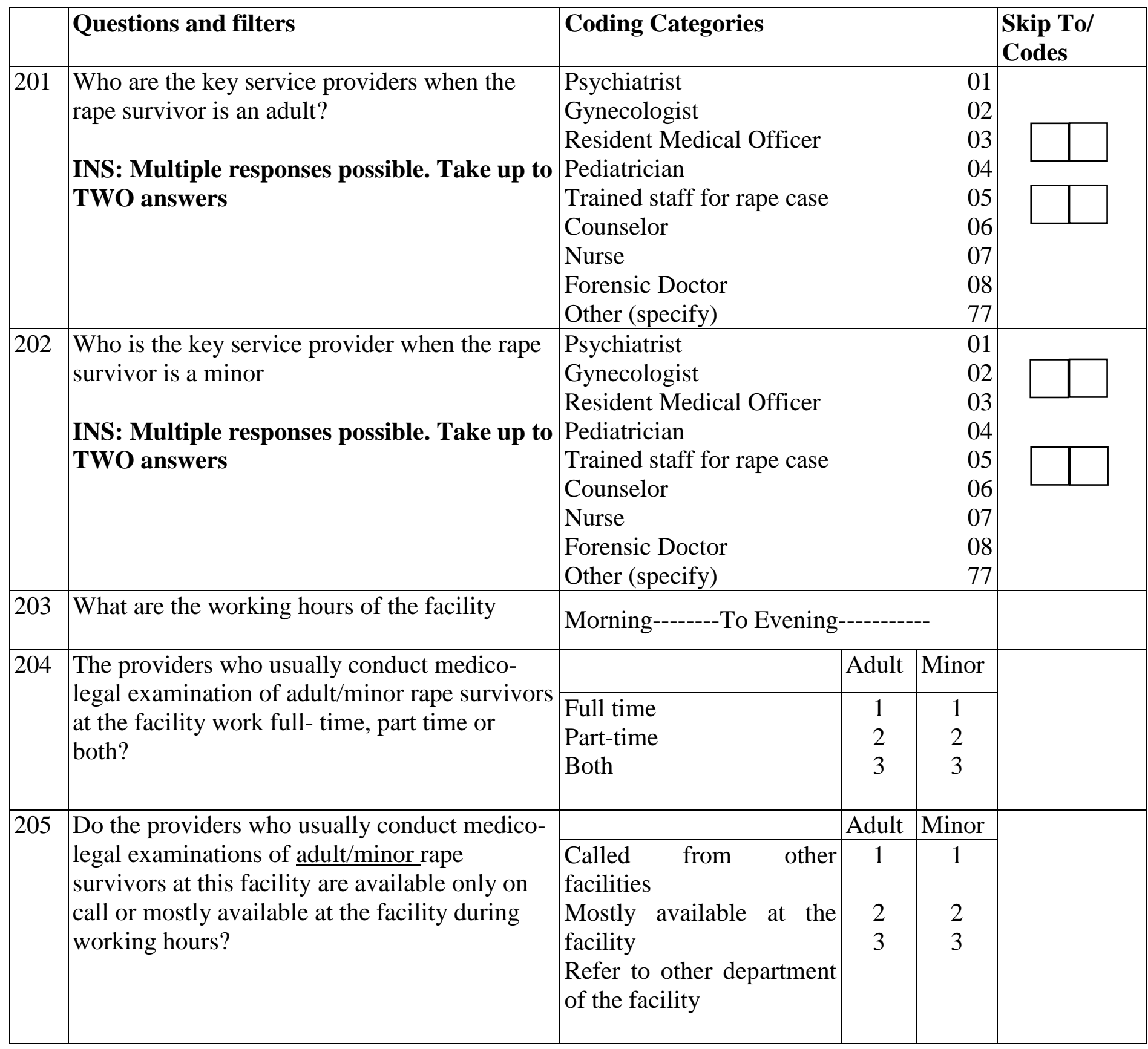




\begin{tabular}{|c|c|c|c|c|}
\hline & Questions and filters & Coding Categories & & $\begin{array}{l}\text { Skip To/ } \\
\text { Codes }\end{array}$ \\
\hline 206 & $\begin{array}{l}\text { Generally, how much time after rape do } \\
\text { survivors come to the facilities for examination } \\
\text { and treatment? }\end{array}$ & $\begin{array}{l}\text { Within } 3 \text { hours } \\
\text { Between 3-6 hours } \\
\text { Between 7-12 hours } \\
\text { Between 13-18 hours } \\
\text { Between 19-24 hours } \\
\text { Second day } \\
\text { Third day } \\
\text { After more than } 3 \text { days } \\
\text { Don't Know }\end{array}$ & $\begin{array}{l}01 \\
02 \\
03 \\
04 \\
05 \\
06 \\
07 \\
08 \\
88\end{array}$ & \\
\hline 207 & $\begin{array}{l}\text { If the rape survivors come to the health facility } \\
\text { first, are they sent to police station or police } \\
\text { post before any physical examination at the } \\
\text { facility or they are provided some services } \\
\text { before referring the case to police }\end{array}$ & $\begin{array}{l}\text { Sent to police before performing any } \\
\text { service } \\
\text { Counseling is done and then sent to } \\
\text { police for reporting } \\
\text { All required services are provided and } \\
\text { then survivor is sent to police } \\
\text { All required services provided and } \\
\text { then information is sent to police } \\
\text { Services provided, not reported to } \\
\text { Police } \\
\text { Don't know }\end{array}$ & $\begin{array}{l}01 \\
02 \\
03 \\
04 \\
05 \\
88\end{array}$ & \\
\hline 208 & $\begin{array}{l}\text { Informing to police is legally mandatory or a } \\
\text { rule of the facility? }\end{array}$ & $\begin{array}{l}\text { A legal requirement } \\
\text { It is a protocol at the facility } \\
\text { No binding but for legal convenience } \\
\text { Don't Know }\end{array}$ & \begin{tabular}{l|} 
\\
2 \\
3 \\
8
\end{tabular} & \\
\hline 209 & $\begin{array}{l}\text { What legal formalities are to be completed by } \\
\text { the survivor at your facility before she is } \\
\text { examined? } \\
\text { INS: Give in same sequence as actions are } \\
\text { taken. }\end{array}$ & 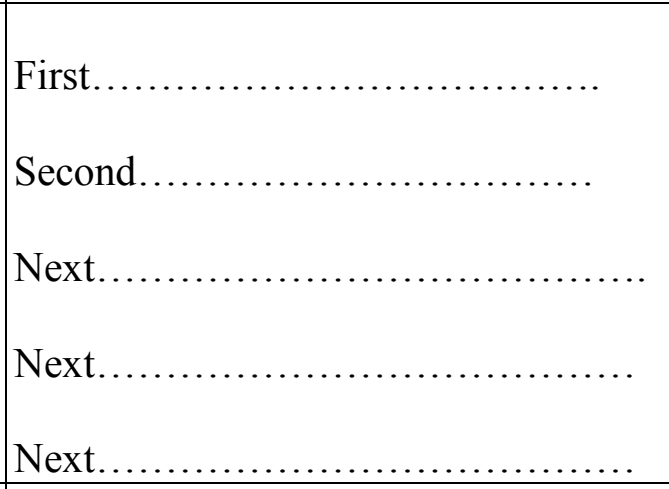 & & \\
\hline 210 & $\begin{array}{l}\text { Generally how much time is taken to complete } \\
\text { these formalities before examination starts }\end{array}$ & ..........min & & \\
\hline 211 & $\begin{array}{l}\text { In case the rape victim had contacted the police } \\
\text { station first, who is she accompanied by when } \\
\text { presented at the health facility? } \\
\text { INS: Multiple answers possible. Take up to } \\
\text { TWO answers. }\end{array}$ & $\begin{array}{l}\text { Lady Police Officer } \\
\text { Any police officer } \\
\text { Head Constable } \\
\text { Constable } \\
\text { None accompanying her the hospital } \\
\text { but given a copy of FIR } \\
\text { Other (specify) }\end{array}$ & \begin{tabular}{l|l}
1 & \\
2 & \\
3 & \\
5 & \\
6 & \\
7 &
\end{tabular} & \\
\hline
\end{tabular}




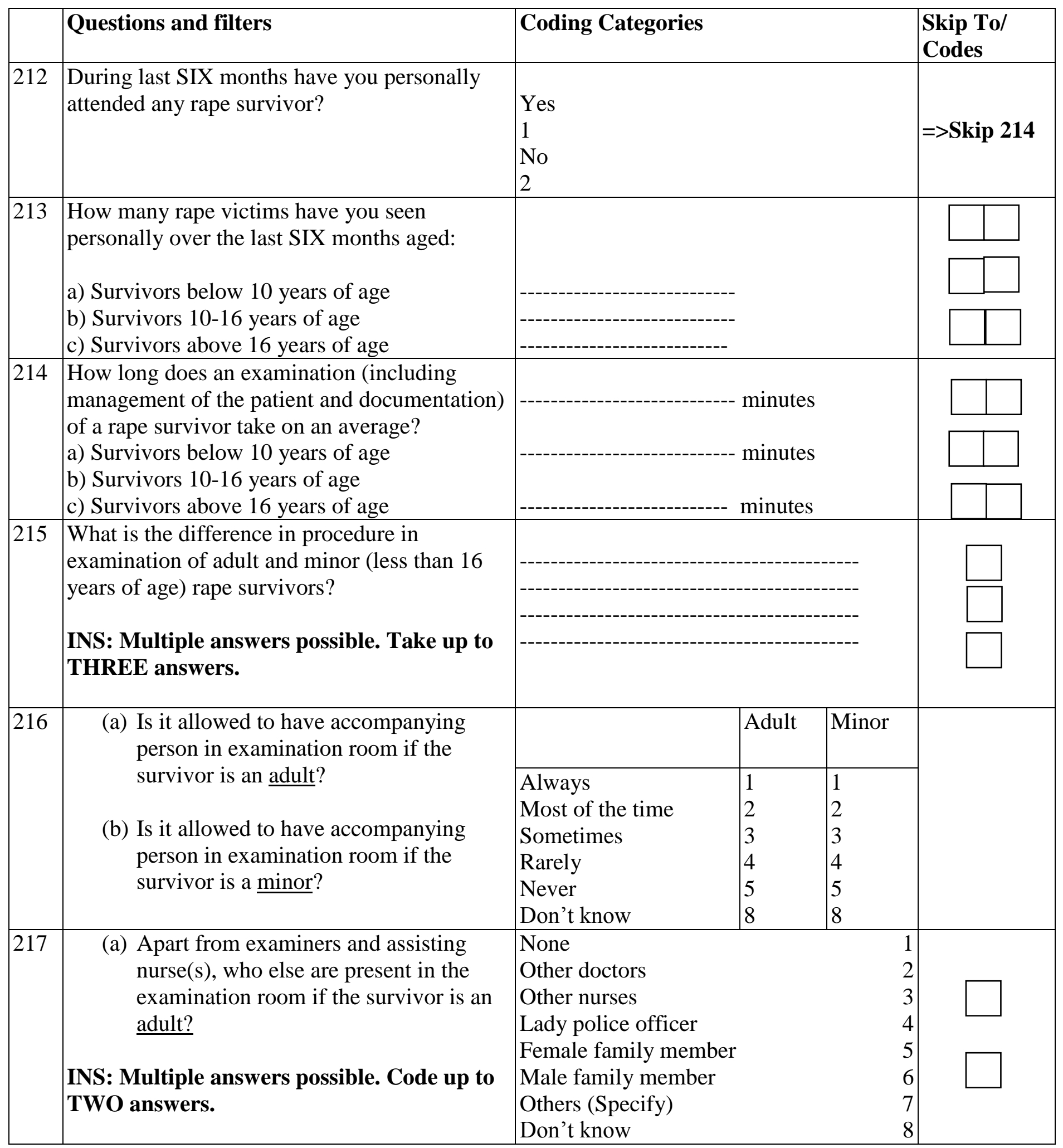




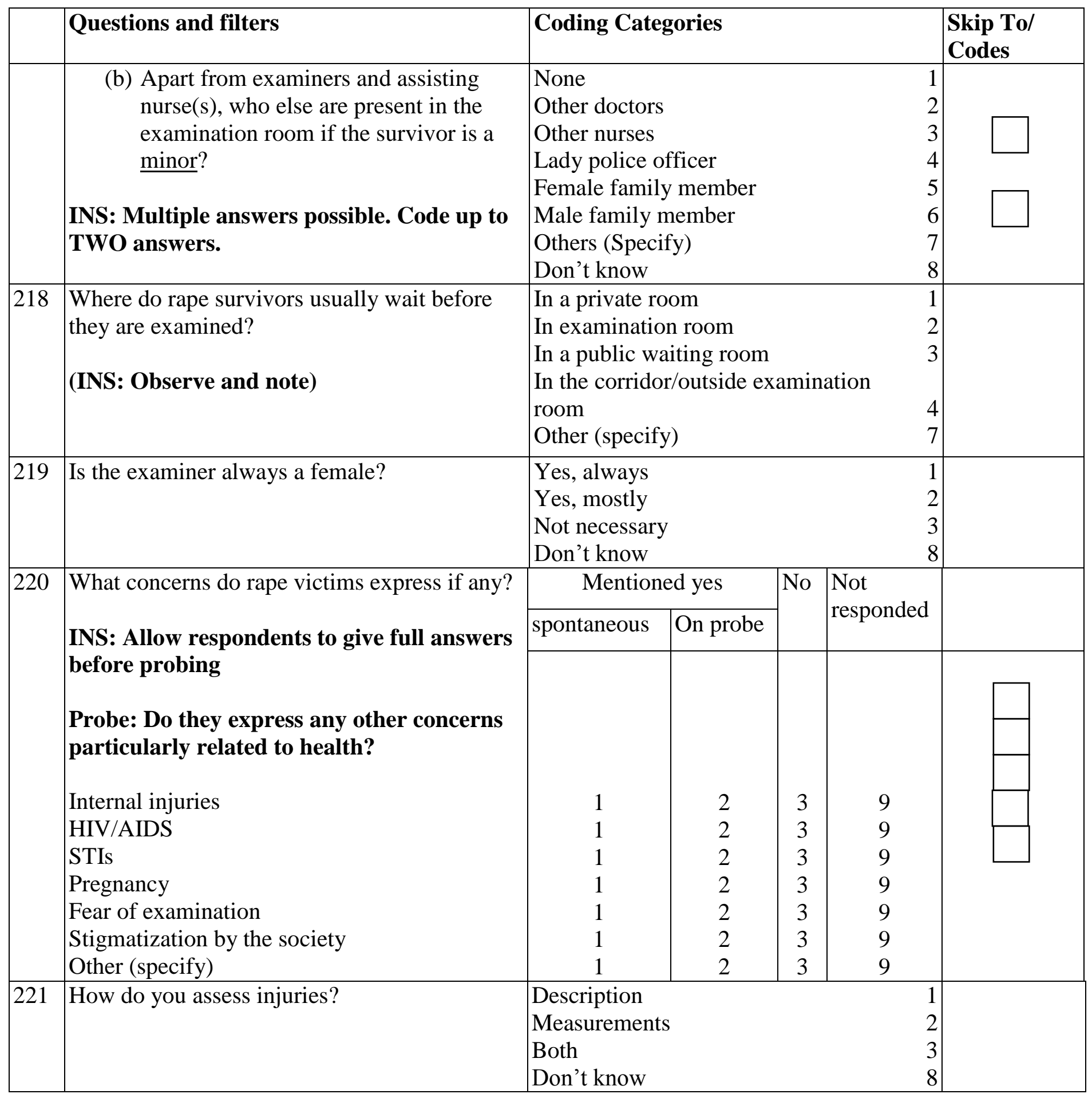




\section{Section 3: STI Prevention}

\begin{tabular}{|c|c|c|c|c|c|c|c|}
\hline & Questions and filters & \multicolumn{5}{|c|}{ Coding Categories } & \begin{tabular}{|l} 
Skip \\
To/Codes
\end{tabular} \\
\hline 301 & Do rape survivors get STI treatment? & \multicolumn{4}{|c|}{$\begin{array}{l}\text { Yes, all rape survivors } \\
\text { Yes, some of the rape survivors } \\
\text { STI treatment is mostly not given } \\
\text { No } \\
\text { Don't know }\end{array}$} & \begin{tabular}{l|}
1 \\
2 \\
3 \\
4 \\
8
\end{tabular} & $\begin{aligned} & \\
\Rightarrow & \text { Skip to } 306 \\
\Rightarrow> & \text { Skip to } 309\end{aligned}$ \\
\hline \multirow[t]{4}{*}{302} & What STI treatment would you give to & \multicolumn{2}{|c|}{ Mentioned yes } & \multirow[t]{2}{*}{ No } & \multirow{2}{*}{\multicolumn{2}{|c|}{$\begin{array}{l}\text { Don't } \\
\text { know }\end{array}$}} & \\
\hline & a patient who has presented after rape? & spontaneous & On probe & & & & \\
\hline & $\begin{array}{l}\text { INS: Note spontaneous answers first } \\
\text { and then probe }\end{array}$ & & & & & & \\
\hline & $\begin{array}{l}\text { Give prophylactic treatment } \\
\text { Refer to STD clinic } \\
\text { Send swab to lab to test for STIs }\end{array}$ & $\begin{array}{l}1 \\
1 \\
1\end{array}$ & $\begin{array}{l}2 \\
2 \\
2\end{array}$ & $\begin{array}{l}3 \\
3 \\
3\end{array}$ & & & \\
\hline 303 & $\begin{array}{l}\text { Who are eligible to receive STI } \\
\text { prevention? }\end{array}$ & \multicolumn{5}{|c|}{$\begin{array}{ll}\text { Everyone } & 1 \\
\text { All adult women } & 2 \\
\text { All non-pregnant adult women } & 3 \\
\text { All non-pregnant adults and children } & 4 \\
\text { All children } & 5 \\
\text { Other (specify) } & 7 \\
\text { Don't know } & 8\end{array}$} & \\
\hline 304 & Do rape survivors get STI treatment? & \multicolumn{4}{|c|}{$\begin{array}{l}\text { All gets as routine STI treatment } \\
\text { Some get and some do not get treatment } \\
\text { All non-pregnant adult women } \\
\text { All non-pregnant adults and children } \\
\text { All children } \\
\text { STI treatment is mostly not given } \\
\text { Other (specify) }\end{array}$} & \begin{tabular}{l|}
1 \\
2 \\
3 \\
4
\end{tabular} & \\
\hline
\end{tabular}




\begin{tabular}{|c|c|c|c|c|}
\hline & Questions and filters & Coding Categories & & $\begin{array}{l}\text { Skip } \\
\text { To/Codes }\end{array}$ \\
\hline $305 \mathrm{a}$ & $\begin{array}{l}\text { What regimen for STI prevention is } \\
\text { used when a rape survivor is an adult } \\
\text { and non-pregnant woman? } \\
\text { INS: Multiple responses possible. } \\
\text { Take up to TWO answers } \\
\text { Correct answer } \\
\begin{array}{l}\text { - One dose each of Ciprofloxacin } \\
500 \mathrm{mg} \text { and Metronidazole } 2 \mathrm{G}\end{array} \\
\text { PLUS Doxycycline } 100 \mathrm{mg} 12 \\
\text { hourly for } 7 \text { days }\end{array}$ & $\begin{array}{l}\text { Ciprofloxacin } 500 \mathrm{mg} \text { one dose one time } \\
\text { Metronidazole } 2 \mathrm{G} \text { one dose one time } \\
\text { One dose each of Ciprofloxacin } 500 \mathrm{mg} \text { and } \\
\text { Metronidazole } 2 \mathrm{G} \\
\text { Doxycycline } 100 \mathrm{mg} \text { (no mention of no of } \\
\text { days and interval) } \\
\text { Doxycycline } 100 \mathrm{mg} \text { for } 7 \text { days (interval not } \\
\text { mentioned) } \\
\text { Doxycycline } 100 \mathrm{mg} \text { for } 7 \text { days, at } 12 \text { hours } \\
\text { interval } \\
\text { Other answers (note down) }\end{array}$ & $\begin{array}{l}6 \\
7\end{array}$ & \\
\hline $305 b$ & $\begin{array}{l}\text { What regimen for STI prevention is } \\
\text { used when a rape survivor is adult and } \\
\text { pregnant? } \\
\text { INS: Multiple answers is possible } \\
\text { Correct answer } \\
\text { - One dose of Ceftriaxone } 125 \mathrm{mg} \\
\text { IM and Metronidazole } 2 \mathrm{G} \\
\text { - PLUS Erythromycin } 500 \mathrm{mg} \text { at } 6 \\
\text { hourly for } 7 \text { days }\end{array}$ & 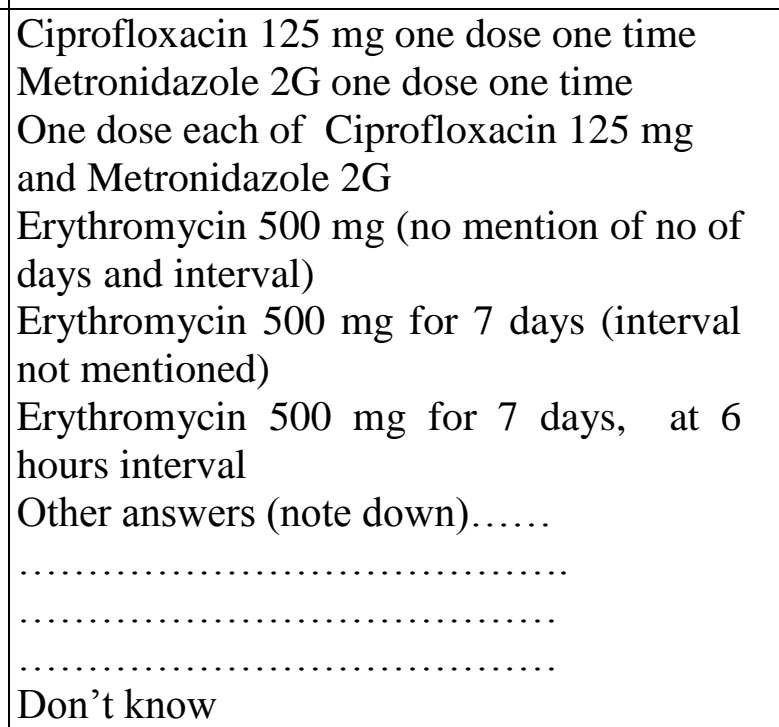 & $\begin{array}{l}1 \\
2\end{array}$ & \\
\hline 306 & $\begin{array}{l}\text { Are anti-emetics given to rape } \\
\text { survivors? }\end{array}$ & $\begin{array}{l}\text { Yes } \\
\text { No }\end{array}$ & $\begin{array}{l}1 \\
2\end{array}$ & $\begin{array}{l}=>\text { Skip } 401 \\
=>\text { Skip } 401\end{array}$ \\
\hline
\end{tabular}




\section{Section 4: HIV Prevention}

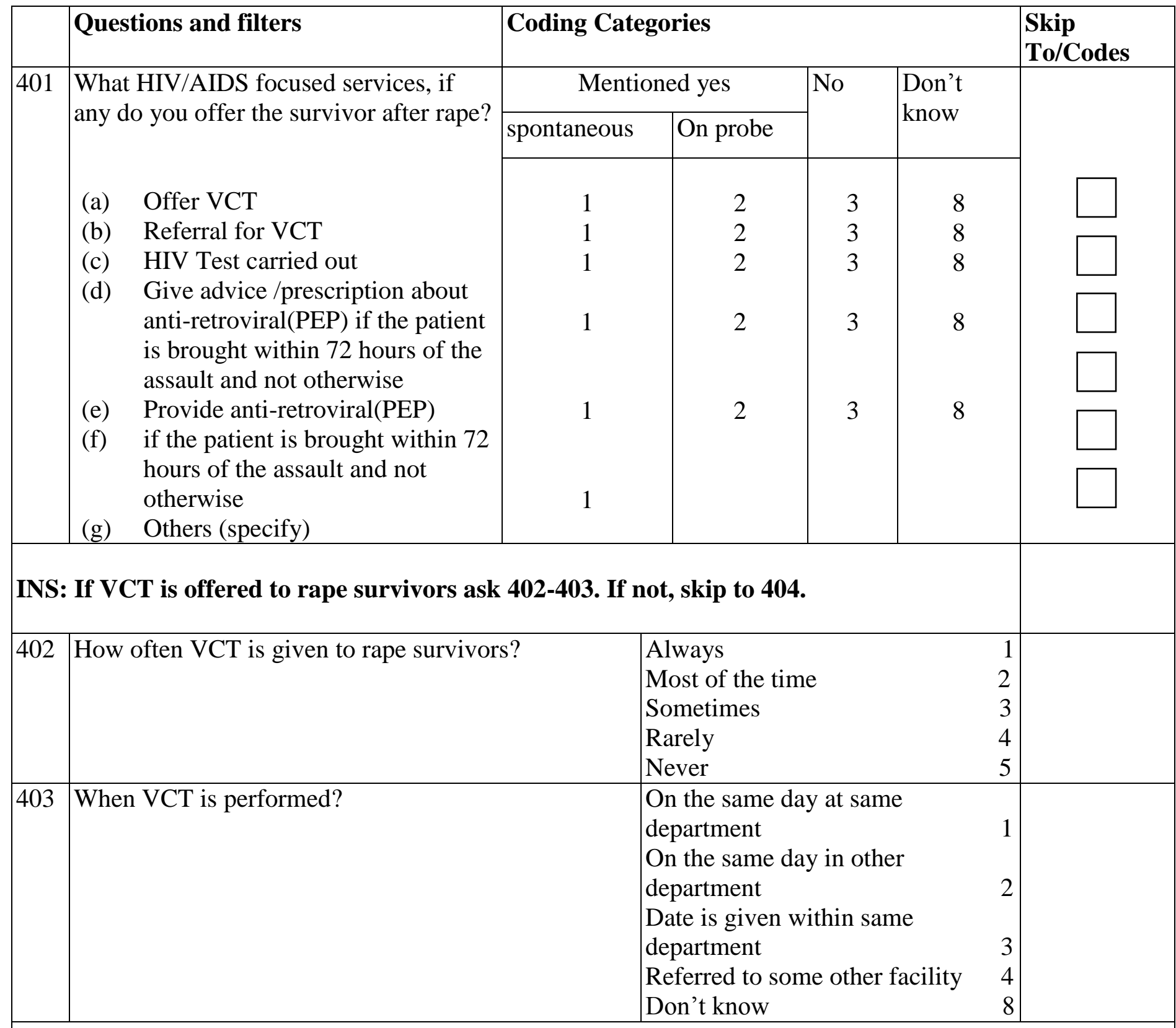

INS: If HIV testing is done for rape survivors ask 405-406. If not, skip to 407.

\begin{tabular}{|c|c|c|c|}
\hline 405 & What HIV test is done? & $\begin{array}{l}\text { Rapid HIV test } \\
\text { Lab based ELIZA } \\
\text { Both if required } \\
\text { Don't know }\end{array}$ & $\begin{array}{l}1 \\
2 \\
3 \\
8\end{array}$ \\
\hline 406 & When do they get the results of the HIV test? & $\begin{array}{l}\text { Immediately } \\
\text { On return visit } \\
\text { Don't know }\end{array}$ & $\begin{array}{l}1 \\
2 \\
8\end{array}$ \\
\hline
\end{tabular}




\begin{tabular}{|c|c|c|c|c|}
\hline & Questions and filters & Coding Categories & & \begin{tabular}{|l|} 
Skip \\
To/Codes
\end{tabular} \\
\hline \multicolumn{5}{|c|}{ INS: If PEP advice/provision mentioned then ask 407-409. If not, skip to 501.} \\
\hline 407 & $\begin{array}{l}\text { Who are eligible to receive PEP? } \\
\text { INS: Multiple responses possible. } \\
\text { Take up to TWO answers }\end{array}$ & $\begin{array}{l}\text { If reporting within } 72 \text { hours of assault } \\
\text { Any time after the assault } \\
\text { She is not HIV positive } \\
\text { Other (specify) } \\
\text { Don't Know }\end{array}$ & $\begin{array}{l}1 \\
2 \\
3 \\
7 \\
8\end{array}$ & \\
\hline 408. & $\begin{array}{l}\text { What PEP regimen is used when rape } \\
\text { survivor is an adult? } \\
\text { Correct answer } \\
\text { - AZT } 300 \mathrm{mg} \text { PO Q } 12 \text { hourly } \\
\text { - } 3 \text { TC } 150 \mathrm{mg} \text { PO Q } 12 \text { hourly }\end{array}$ & $\begin{array}{l}\text { AZT 300mg + 3TC } 150 \mathrm{gm} \text { twice a day at } \\
\text { 12hr interval (correct) } \\
\text { AZT300mg + 3TC } 150 \mathrm{gm} \text { (either dose or } \\
\text { interval or both was not mentioned } \\
\text { correctly) } \\
\text { Other wrong answers (e.g: only one } \\
\text { medicine mentioned) } \\
\text { Other (note down) } \\
\text { Don't know }\end{array}$ & 1 & \\
\hline 409 & Is the full PEP regimen given at once? & $\begin{array}{l}\text { Yes, given 28-day regimen } \\
\text { No, medicines only for a few days } \\
\text { No medicine is given, only prescribed } \\
\text { Don't know }\end{array}$ & 2 & \\
\hline
\end{tabular}




\section{Section 5: Emergency Contraception}

\begin{tabular}{|c|c|c|c|c|}
\hline & Questions and filters & Coding Categories & & $\begin{array}{l}\text { Skip } \\
\text { To/Codes }\end{array}$ \\
\hline 501 & Do rape survivors receive pregnancy test? & $\begin{array}{l}\text { Always } \\
\text { Most of the time } \\
\text { Sometimes } \\
\text { Rarely } \\
\text { Never }\end{array}$ & $\begin{array}{l}1 \\
2 \\
3 \\
4 \\
5\end{array}$ & \\
\hline 502 & $\begin{array}{l}\text { Are rape survivors offered emergency } \\
\text { contraceptive }\end{array}$ & $\begin{array}{l}\text { Yes } \\
\text { No }\end{array}$ & & $=>$ Skip 601 \\
\hline 503 & Which women get emergency contraception? & $\begin{array}{l}\text { Everyone } \\
\text { All non pregnant adult } \\
\text { women } \\
\text { All non-pregnant adult } \\
\text { women who are not on a } \\
\text { reliable method of } \\
\text { contraception } \\
\text { If raped during danger } \\
\text { period } \\
\text { Other (Specify) }\end{array}$ & $\begin{array}{l}4 \\
7 \\
\end{array}$ & \\
\hline 504 & $\begin{array}{l}\text { How long after the assault ECP could be given } \\
\text { or ECP is effective? }\end{array}$ & $\begin{array}{l}12 \text { hrs } \\
24 \text { hrs } \\
\text { Within } 48 \text { hrs } \\
\text { Within } 72 \text { hrs } \\
\text { Up to five days } \\
\text { Don't know }\end{array}$ & $\begin{array}{l}1 \\
2\end{array}$ & \\
\hline 505 & $\begin{array}{l}\text { Do you stock emergency contraceptive for } \\
\text { rape survivors? }\end{array}$ & $\begin{array}{l}\text { Yes } \\
\text { No, only prescribe } \\
\text { Do not advice ECP } \\
\text { Don't know }\end{array}$ & 2 & \\
\hline
\end{tabular}




\section{Section 6: Counseling}

\begin{tabular}{|c|c|c|c|c|}
\hline & Questions and filters & Coding Categories & & $\begin{array}{l}\text { Skip } \\
\text { To/Codes }\end{array}$ \\
\hline 601 & $\begin{array}{l}\text { Does the facility offer counseling service to all the } \\
\text { rape survivor cases? }\end{array}$ & $\begin{array}{l}\text { Yes } \\
\text { No }\end{array}$ & \begin{tabular}{r|r}
1 \\
2
\end{tabular} & \\
\hline 602 & Does this facility have a counselor? & $\begin{array}{l}\text { Yes } \\
\text { No }\end{array}$ & $\begin{array}{l}1 \\
2\end{array}$ & \\
\hline 603 & $\begin{array}{l}\text { Does the facility have trained staff to carry out } \\
\text { counseling? }\end{array}$ & $\begin{array}{l}\text { Yes } \\
\text { No }\end{array}$ & $\begin{array}{l}1 \\
2\end{array}$ & $=>$ Skip 606 \\
\hline 604 & $\begin{array}{l}\text { Do you refer the case elsewhere for counseling and } \\
\text { support? }\end{array}$ & $\begin{array}{l}\text { Yes } \\
\text { No }\end{array}$ & $\begin{array}{l}1 \\
2\end{array}$ & $=>$ Skip 606 \\
\hline 605 & $\begin{array}{l}\text { Where? } \\
\text { INS: Multiple responses possible. Take up to } \\
\text { TWO answers. }\end{array}$ & $\begin{array}{l}\text { One stop crisis center } \\
\text { Psychiatric department at the } \\
\text { Facility } \\
\text { Psychiatric department of } \\
\text { other facility } \\
\text { NGO } \\
\text { Other }\end{array}$ & $\begin{array}{c}3 \\
4 \\
7\end{array}$ & \\
\hline 606 & $\begin{array}{l}\text { How often do you offer rape victims for } \\
\text { trauma/psychological counseling? }\end{array}$ & $\begin{array}{l}\text { Always } \\
\text { Sometime } \\
\text { Rarely } \\
\text { Never }\end{array}$ & $\begin{array}{l}1 \\
2 \\
3 \\
4\end{array}$ & \\
\hline 607 & How counseling session/s are carried out? & $\begin{array}{l}\text { Only on the day rape survivor } \\
\text { comes for examination } \\
\text { Later on } \\
\text { Don't know }\end{array}$ & $\begin{array}{l}1 \\
2 \\
8\end{array}$ & \\
\hline 607 & How many sessions usually use for counseling? & ----------Sessions & & \\
\hline 608 & Usually how long is the counseling session? & _Minutes & & \\
\hline 609 & $\begin{array}{l}\text { How often do you offer rape victims for legal advice } \\
\text { / support? }\end{array}$ & $\begin{array}{l}\text { Always } \\
\text { Sometimes } \\
\text { Rarely } \\
\text { Never }\end{array}$ & $\begin{array}{l}1 \\
2 \\
3 \\
4\end{array}$ & \\
\hline
\end{tabular}




\section{Section 7: Medico-legal Examination}

\begin{tabular}{|c|c|c|c|c|c|c|c|c|c|}
\hline & \multicolumn{4}{|c|}{ Questions and filters } & \multicolumn{4}{|c|}{ Coding Categories } & \begin{tabular}{|l|} 
Skip \\
To/Codes
\end{tabular} \\
\hline 701 & \multicolumn{4}{|c|}{$\begin{array}{l}\text { Who undresses the patient before the } \\
\text { examination? }\end{array}$} & \multicolumn{4}{|c|}{$\begin{array}{l}\text { Patients themselves } \\
\text { Nurse } \\
\text { Examining provider }\end{array}$} & \\
\hline 702 & \multicolumn{4}{|c|}{$\begin{array}{l}\text { Is the patient undressed on a sheet of } \\
\text { paper? }\end{array}$} & \multicolumn{4}{|l|}{$\begin{array}{l}\text { Yes } \\
\text { No }\end{array}$} & \\
\hline 703 & \multicolumn{4}{|c|}{$\begin{array}{l}\text { What procedures are followed before } \\
\text { the medical examination? } \\
\text { INS: Multiple responses possible. } \\
\text { Take up to THREE answers. }\end{array}$} & \multicolumn{4}{|c|}{$\begin{array}{l}\text { Counseling } \\
\text { Full explanation of the medico- } \\
\text { legal examination and what }\end{array}$} & \\
\hline 704 & \multicolumn{4}{|c|}{$\begin{array}{l}\text { Are the medical and forensic } \\
\text { examinations done together or } \\
\text { separately? }\end{array}$} & \multicolumn{4}{|c|}{$\begin{array}{l}\text { Together } \\
\text { Separately }\end{array}$} & \\
\hline $705 a$ & \multicolumn{9}{|c|}{$\begin{array}{l}\text { What different things do you collect when examining a rape survivor? } \\
\text { Spontaneous answer: (Record answer in column } 2 \text { table below) }\end{array}$} \\
\hline $705 \mathrm{~b}$ & \multirow{2}{*}{\multicolumn{9}{|c|}{$\begin{array}{l}\text { Probe: Do you collect anything else? Here are some other things one may collect during } \\
\text { examination. Tell me whether you collect any of these? (Record answer in column } 3 \text { table } \\
\text { below) } \\
\text { INS: Now ask each item individually whether answered spontaneously or on probe. }\end{array}$}} \\
\hline $705 \mathrm{c}$ & & & & & & & & & \\
\hline & \multirow{3}{*}{$\begin{array}{l}\text { Things } \\
\text { collected } \\
\text { during } \\
\text { examination }\end{array}$} & \multicolumn{3}{|c|}{ Mentioned } & \multirow{2}{*}{\multicolumn{5}{|c|}{$705 \mathrm{c}$}} \\
\hline & & $705 a$ & $705 \mathrm{k}$ & & & & & & \\
\hline & & $\begin{array}{l}\text { Spontan } \\
\text { eously }\end{array}$ & $\begin{array}{l}\text { Yes on } \\
\text { probe }\end{array}$ & $\begin{array}{l}\mathrm{N} \\
\mathrm{o}\end{array}$ & Always & $\begin{array}{l}\text { Mostly } \\
\text { ( } 80 \% \\
\text { of the } \\
\text { cases) }\end{array}$ & $\begin{array}{l}\text { Some } \\
\text { times } \\
\text { (50\%of } \\
\text { the } \\
\text { cases) }\end{array}$ & $\begin{array}{l}\text { Less } \\
\text { frequently }\end{array}$ & Rarely/Never \\
\hline $\mathrm{a}$ & Panties & 1 & 2 & 3 & 1 & 2 & 3 & 4 & 5 \\
\hline b & \begin{tabular}{|l|} 
Sanitary \\
pad (if \\
used)
\end{tabular} & 1 & 2 & 3 & 1 & 2 & 3 & 4 & 5 \\
\hline c. & $\begin{array}{l}\text { External } \\
\text { anal swab }\end{array}$ & 1 & 2 & 3 & 1 & 2 & 3 & 4 & 5 \\
\hline d & $\begin{array}{l}\text { Tampon (if } \\
\text { used) }\end{array}$ & 1 & 2 & 3 & 1 & 2 & 3 & 4 & 5 \\
\hline
\end{tabular}




\begin{tabular}{|c|c|c|c|c|c|c|c|c|c|}
\hline $\mathrm{e}$ & $\begin{array}{l}\text { External } \\
\text { genital } \\
\text { swab }\end{array}$ & 1 & 2 & 3 & 1 & 2 & 3 & 4 & 5 \\
\hline f & $\begin{array}{l}\text { Deep } \\
\text { vaginal } \\
\text { swab }\end{array}$ & 1 & 2 & 3 & 1 & 2 & 3 & 4 & 5 \\
\hline g & $\begin{array}{l}\text { Cervical } \\
\text { swab }\end{array}$ & 1 & 2 & 3 & 1 & 2 & 3 & 4 & 5 \\
\hline h. & $\begin{array}{l}\text { Reference } \\
\text { DNA } \\
\text { sample }\end{array}$ & 1 & 2 & 3 & 1 & 2 & 3 & 4 & 5 \\
\hline i. & $\begin{array}{l}\text { Nail } \\
\text { scraping }\end{array}$ & 1 & 2 & 3 & 1 & 2 & 3 & 4 & 5 \\
\hline j. & Hair & 1 & 2 & 3 & 1 & 2 & 3 & 4 & 5 \\
\hline $\mathrm{k}$. & Pubic Hair & 1 & 2 & 3 & 1 & 2 & 3 & 4 & 5 \\
\hline 1. & Semen stain & 1 & 2 & 3 & 1 & 2 & 3 & 4 & 5 \\
\hline $\mathrm{m}$. & Blood stain & 1 & 2 & 3 & 1 & 2 & 3 & 4 & 5 \\
\hline
\end{tabular}

\begin{tabular}{|c|c|c|c|c|}
\hline & Questions and filters & Coding Categories & & Skip To/Codes \\
\hline 706 & $\begin{array}{l}\text { Do you use a pre-packaged rape kit when } \\
\text { conducting a medico-legal / forensic examination? }\end{array}$ & $\begin{array}{l}\text { Yes } \\
\text { No }\end{array}$ & $\begin{array}{l}1 \\
2\end{array}$ & => Skip 710 \\
\hline 707 & What is the source of supply of these kits? & $\begin{array}{l}\text { Police } \\
\text { Government Depot } \\
\text { Purchased from the market } \\
\text { Other }\end{array}$ & $\begin{array}{l}1 \\
2 \\
3 \\
7\end{array}$ & \\
\hline 708 & $\begin{array}{l}\text { Would you say that the pre-packaged rape kits are } \\
\text { in pristine condition always, mostly, sometimes, } \\
\text { seldom, never? }\end{array}$ & $\begin{array}{l}\text { Always } \\
\text { Mostly } \\
\text { Sometimes } \\
\text { Seldom } \\
\text { Never } \\
\text { Don't know }\end{array}$ & $\begin{array}{l}1 \\
2 \\
3 \\
4 \\
5 \\
8\end{array}$ & \\
\hline 709 & Is it available in your stock now? & $\begin{array}{l}\text { Yes } \\
\text { No } \\
\text { Don't Know }\end{array}$ & $\begin{array}{l}1 \\
2 \\
8\end{array}$ & \\
\hline 710 & $\begin{array}{l}\text { Where are the medico-legal/ forensic examination } \\
\text { reports/kits kept after completion? }\end{array}$ & $\begin{array}{l}\text { In the examination room } \\
\text { In the facility manager's office } \\
\text { Given to Police } \\
\text { Other (specify) } \\
\text { Don't know }\end{array}$ & $\begin{array}{l}1 \\
2 \\
3 \\
7 \\
8\end{array}$ & $=>$ Skip 801 \\
\hline 711 & $\begin{array}{l}\text { Are the reports/kits kept in a locked cupboard } \\
\text { (after they are completed? }\end{array}$ & $\begin{array}{l}\text { Yes } \\
\text { No } \\
\text { Don't know }\end{array}$ & $\begin{array}{l}1 \\
2 \\
8\end{array}$ & \\
\hline
\end{tabular}




\begin{tabular}{|c|c|c|c|}
\hline 712 & Who keeps the key? & $\begin{array}{l}\text { Nurse in-charge } \\
\text { Emergency Room/casualty chief } \\
\text { Medical officer } \\
\text { Facility superintendent } \\
\text { Matron } \\
\text { Other (specify) }\end{array}$ & \begin{tabular}{l|}
1 \\
2 \\
3 \\
4 \\
5 \\
7
\end{tabular} \\
\hline
\end{tabular}




\section{Section 8: Protocols/Clinical Management Guidelines}

\begin{tabular}{|c|c|c|c|c|}
\hline & Questions and filters & Coding Categories & & $\begin{array}{l}\text { Skip } \\
\text { To/Codes }\end{array}$ \\
\hline 801 & $\begin{array}{l}\text { Are there protocols or guidelines for the } \\
\text { management of rape survivors? }\end{array}$ & $\begin{array}{l}\text { Yes } \\
\text { No } \\
\text { Don't know }\end{array}$ & 1 & $\begin{array}{l}=>\text { Skip to } 901 \\
=>\text { Skip to } 901\end{array}$ \\
\hline 802 & Where are they kept? & $\begin{array}{l}\text { In the examination room } \\
\text { Facility manager's office } \\
\text { Other (specify) } \\
\text { Don't know }\end{array}$ & 1 & \\
\hline 803 & Are they displayed or kept in a drawer? & \begin{tabular}{|l} 
Displayed \\
In drawer \\
Don't Know
\end{tabular} & 1 & \\
\hline 804 & $\begin{array}{l}\text { Are they available right now? } \\
\text { (ASK TO SHOW) }\end{array}$ & $\begin{array}{l}\text { Yes (showed) } \\
\text { Yes, but could not show } \\
\text { No }\end{array}$ & 3 & \\
\hline
\end{tabular}




\section{Section 9: Training}

\begin{tabular}{|c|c|c|c|}
\hline & Questions and filters & Coding Categories & \begin{tabular}{|l|} 
Skip \\
To/Codes
\end{tabular} \\
\hline 901 & $\begin{array}{l}\text { Is there any special training for examining rape } \\
\text { cases at the facility: } \\
\text { (a) For Doctors } \\
\text { (b) For Nurses }\end{array}$ & $\begin{array}{l}\text { Yes } \\
\text { No } \\
\text { Yes } \\
\text { No }\end{array}$ & \\
\hline 902 & $\begin{array}{l}\text { Have you ever received any formal training on the } \\
\text { management of rape? }\end{array}$ & $\begin{array}{l}\text { Yes } \\
\text { No }\end{array}$ & $=>$ Skip to 907 \\
\hline 903 & $\begin{array}{l}\text { How many different training courses have you } \\
\text { attended in management of rape? }\end{array}$ & --Give number & \\
\hline 904 & $\begin{array}{l}\text { In which year did you receive the last training of } \\
\text { management of rape? }\end{array}$ & Year & \\
\hline 905 & How long was your last training? & Days & \\
\hline
\end{tabular}




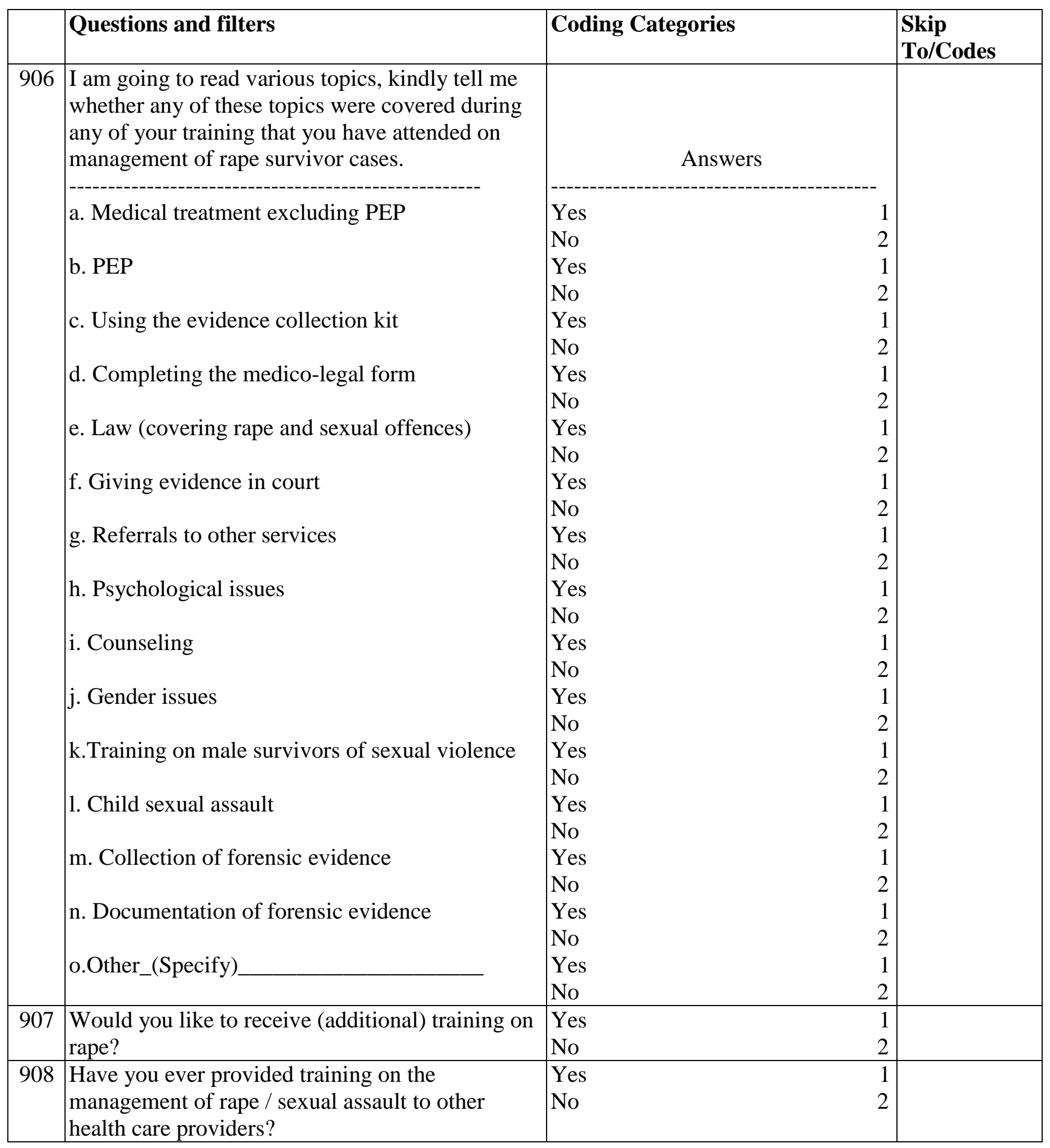




\section{Section 10: Attitudes}

\begin{tabular}{|c|c|c|c|c|c|c|c|}
\hline 1001 & $\begin{array}{l}\text { I am going to read some statements about } \\
\text { rape. I would like you to tell me whether you } \\
\text { strongly agree, agree, disagree or strongly } \\
\text { disagree with the statements }\end{array}$ & $\begin{array}{l}\text { Strongly } \\
\text { agree }\end{array}$ & Agree & $\begin{array}{l}\text { No } \\
\text { opinion }\end{array}$ & $\begin{array}{l}\text { Disag } \\
\text { ree }\end{array}$ & $\begin{array}{l}\text { Strongly } \\
\text { disagree }\end{array}$ & $\begin{array}{l}\text { Did not } \\
\text { answer }\end{array}$ \\
\hline a. & A boy can be sexually abused & 1 & 2 & 3 & 4 & 5 & 8 \\
\hline b. & A husband can rape his wife & 1 & 2 & 3 & 4 & 5 & 8 \\
\hline c. & $\begin{array}{l}\text { Forced sex with sex workers cannot be called } \\
\text { rape }\end{array}$ & 1 & 2 & 3 & 4 & 5 & 8 \\
\hline d. & $\begin{array}{l}\text { If a woman is drunk, it is impossible to say } \\
\text { that she refused sex and got raped }\end{array}$ & 1 & 2 & 3 & 4 & 5 & 8 \\
\hline $\mathrm{e}$. & Some women lie about rape to punish men & 1 & 2 & 3 & 4 & 5 & 8 \\
\hline f. & $\begin{array}{l}\text { Rape happens because women move around } \\
\text { unescorted and carelessly. }\end{array}$ & 1 & 2 & 3 & 4 & 5 & 8 \\
\hline g. & $\begin{array}{l}\text { Provocative dress and gestures of women are } \\
\text { often, the cause of rape. }\end{array}$ & 1 & 2 & 3 & 4 & 5 & 8 \\
\hline $\mathrm{h}$. & Only certain types of women are raped & 1 & 2 & 3 & 4 & 5 & 8 \\
\hline i. & $\begin{array}{l}\text { A woman who is raped brings shame on her } \\
\text { family }\end{array}$ & 1 & 2 & 3 & 4 & 5 & 8 \\
\hline $\mathrm{j}$. & $\begin{array}{l}\text { It is disgraceful for women to bring rape } \\
\text { cases to court }\end{array}$ & 1 & 2 & 3 & 4 & 5 & 8 \\
\hline $\mathrm{k}$. & $\begin{array}{l}\text { A woman who has been raped could have a } \\
\text { serious medical problem }\end{array}$ & 1 & 2 & 3 & 4 & 5 & 8 \\
\hline 1. & $\begin{array}{l}\text { A child who has been raped is an emergency } \\
\text { medical case }\end{array}$ & 1 & 2 & 3 & 4 & 5 & 8 \\
\hline $\mathrm{m}$. & $\begin{array}{l}\text { A person rarely dies from injuries after rape } \\
\text { and so they should wait for their turn for } \\
\text { health care }\end{array}$ & 1 & 2 & 3 & 4 & 5 & 8 \\
\hline n. & $\begin{array}{l}\text { Rape is more serious for someone who is a } \\
\text { virgin }\end{array}$ & 1 & 2 & 3 & 4 & 5 & 8 \\
\hline o. & Rape leaves obvious signs of physical injury & 1 & 2 & 3 & 4 & 5 & 8 \\
\hline p. & $\begin{array}{l}\text { Very delayed punishment or non-punishment } \\
\text { of perpetrators encourages rape. }\end{array}$ & 1 & 2 & 3 & 4 & 5 & 8 \\
\hline
\end{tabular}




\section{Section 11: Multisectoral Linkages}

\begin{tabular}{|c|c|c|c|c|}
\hline & Questions and filters & Coding Categories & & $\begin{array}{l}\text { Skip } \\
\text { To/Codes }\end{array}$ \\
\hline 1101 & $\begin{array}{l}\text { How would you describe the relationship between } \\
\text { this health care facility and police over rape cases }\end{array}$ & $\begin{array}{l}\text { Participatory } \\
\text { Neutral } \\
\text { Passive } \\
\text { No relationship }\end{array}$ & $\begin{array}{l}1 \\
2 \\
3 \\
4\end{array}$ & \\
\hline 1102 & $\begin{array}{l}\text { Is there an established link of your facility with } \\
\text { NGOs? }\end{array}$ & $\begin{array}{l}\text { Yes } \\
\text { No }\end{array}$ & $\begin{array}{l}1 \\
2\end{array}$ & \\
\hline 1103 & If yes, which ones? Give the names. & 1. & & \\
\hline 1104 & $\begin{array}{l}\text { How would you describe the relationship between } \\
\text { this healthcare facility and NGOs over rape cases? }\end{array}$ & $\begin{array}{l}\text { Proactive } \\
\text { Cooperative } \\
\text { Non-cooperative }\end{array}$ & $\begin{array}{l}1 \\
2 \\
3 \\
\end{array}$ & \\
\hline 1105 & $\begin{array}{l}\text { What referrals are provided to the survivor? } \\
\text { INS: Multiple answers possible }\end{array}$ & $\begin{array}{l}\text { None } \\
\text { Legal support - lawyer } \\
\text { NGOs } \\
\text { Counselors } \\
\text { One stop crisis centre } \\
\text { Other (Specify) }\end{array}$ & $\begin{array}{l}1 \\
2 \\
3 \\
4 \\
5 \\
7\end{array}$ & \\
\hline 1106 & $\begin{array}{l}\text { How many times did you give evidence in the } \\
\text { court in the past year? }\end{array}$ & Give number & & \\
\hline
\end{tabular}

Thank you for participation! 


\section{Appendix B: Situation Analysis of First Point of Contact for Survivors of Sexual Assault}

\section{Police Facility}

Facility Identification

\begin{tabular}{|c|c|c|c|}
\hline $\begin{array}{l}\text { Q. } \\
\text { No. }\end{array}$ & Questions and Filters & Coding Categories & Codes \\
\hline 1 & Schedule Serial Number & & \\
\hline 2 & Country & $\begin{array}{ll}\text { India } & 1 \\
\text { Bangladesh } & 2\end{array}$ & \\
\hline 3 & City & $\begin{array}{lc}\text { Delhi } & 1 \\
\text { Vadodara } & 2 \\
\text { Lucknow } & 3 \\
\text { Bangalore } & 4 \\
\text { Dhaka } & 5 \\
\text { Chittagong } & 6 \\
\text { Khulna } & 7 \\
\text { Tangail..............8 } \\
\end{array}$ & \\
\hline 4 & Name of the facility & Give name............ & \\
\hline 5 & Date of interview & $\overline{\mathrm{DD} / \mathrm{MM} / \mathrm{YYYY}}$ & \\
\hline 6 & Name of the Interviewer & & \\
\hline 7 & Interview completed in & $\begin{array}{ll}1 \text { visit } & 1 \\
2 \text { visits } & 2\end{array}$ & \\
\hline
\end{tabular}


Section 1: Demographic characteristics

\begin{tabular}{|c|c|c|c|}
\hline & Questions and filters & Coding Categories & \begin{tabular}{|l} 
Skip To/ \\
Codes
\end{tabular} \\
\hline 101 & Gender (Observe) & \begin{tabular}{|l} 
Male \\
Female
\end{tabular} & \\
\hline 102 & How old were you on your last birthday? & \begin{tabular}{|l|}
$<35$ years \\
$35-39$ years \\
$40-49$ years \\
50 and more years \\
\end{tabular} & \\
\hline 103 & $\begin{array}{l}\text { What is the highest level of education you have } \\
\text { obtained? }\end{array}$ & \begin{tabular}{|l|} 
Matriculate \\
Higher secondary \\
Under graduate \\
Graduate \\
Post graduate \\
Other (specify)
\end{tabular} & $\begin{array}{l}1 \\
2 \\
3 \\
4 \\
5 \\
7\end{array}$ \\
\hline 104 & $\begin{array}{l}\text { How long have you been working at this } \\
\text { station/post? }\end{array}$ & . $\ldots \ldots \ldots \ldots \ldots \ldots \ldots$ & \\
\hline 105 & $\begin{array}{l}\text { In total, how long have you been in police } \\
\text { department? }\end{array}$ & Years & \\
\hline 106 & What is your rank? (Please write) & \begin{tabular}{|l|} 
Constable \\
Head Constable \\
Sub Inspector \\
Inspector \\
D S P \\
S P \\
Other (specify)
\end{tabular} & $\frac{2}{4}$ \\
\hline
\end{tabular}




\section{Section 2: Training history}

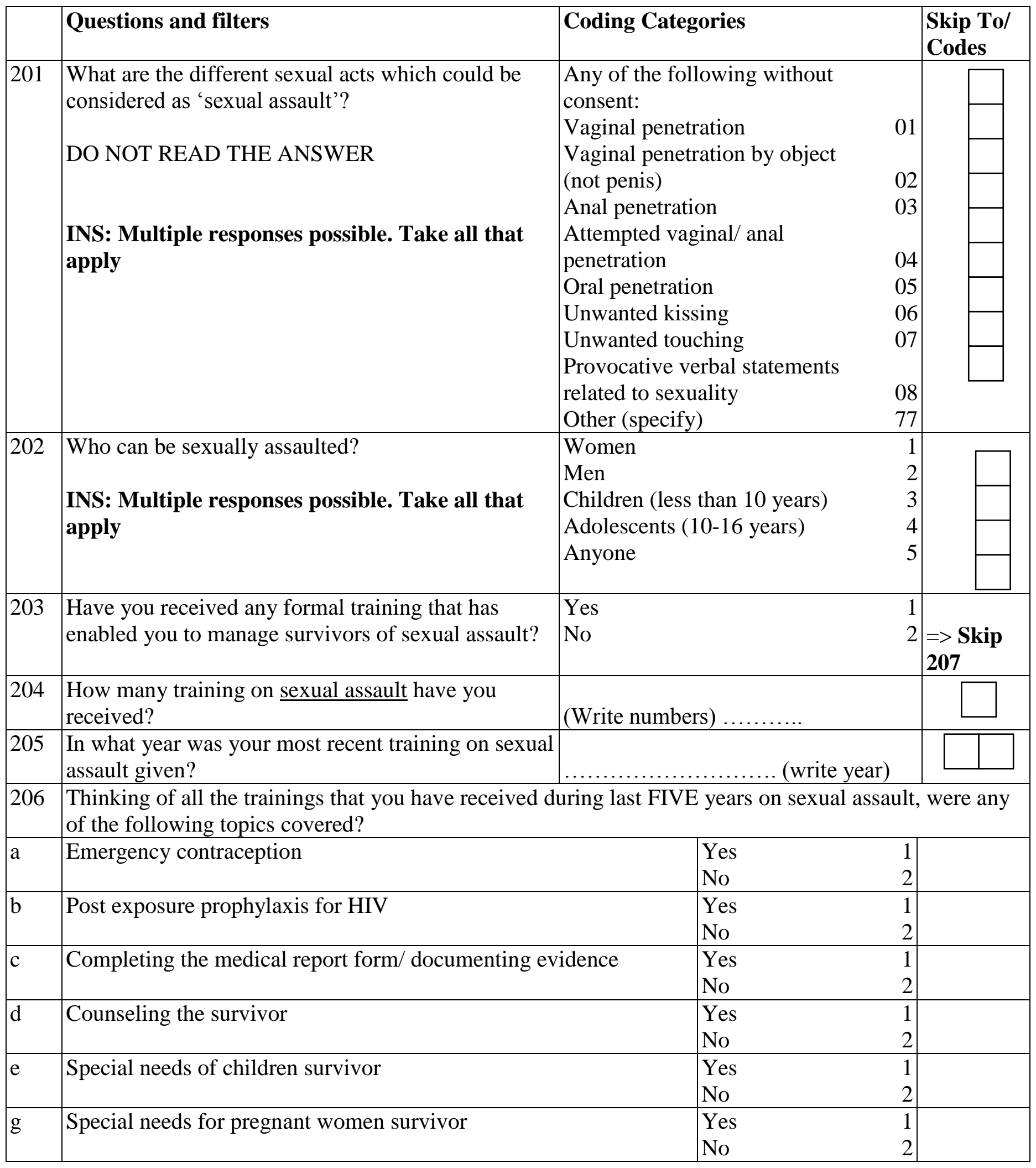




\begin{tabular}{|l|l|l|l|l|}
\hline $\mathrm{h}$ & Special needs for the mentally and physically challenged survivor & Yes & 1 & \\
& & No & 2 & \\
\hline $\mathrm{i}$ & Rape laws & Yes & 1 & \\
\hline $\mathrm{j}$ & Forensic evidence collection & Yes & 1 & \\
\hline $\mathrm{k}$ & Giving evidence in court & No & 2 & \\
& & Yes & 1 & \\
\hline 1 & Role of professional counselors & No & 1 & \\
& & Yes & 2 & \\
\hline $\mathrm{m}$ & Role of police officers in rape survivor case & No & 1 & \\
& & Yes & 2 & \\
\hline 207 & Do you feel that you need more training in order to provide & No & 1 & \\
& appropriate care to survivors of sexual assault? & Yes & 2 & \\
\hline
\end{tabular}




\section{Section 3: Service provision}

\begin{tabular}{|c|c|c|c|}
\hline & Questions and filters & Coding Categories & $\begin{array}{l}\text { Skip To/ } \\
\text { Codes }\end{array}$ \\
\hline 301 & $\begin{array}{l}\text { In your opinion, what proportion of } \\
\text { sexual assault cases that occur in your } \\
\text { area during last month are reported to } \\
\text { the police? }\end{array}$ & 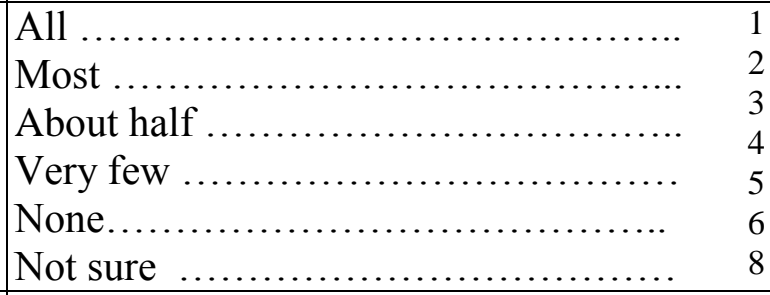 & \\
\hline 302 & $\begin{array}{l}\text { In the last } 6 \text { months, about how many } \\
\text { sexual assault survivors have you } \\
\text { personally attended to? }\end{array}$ & 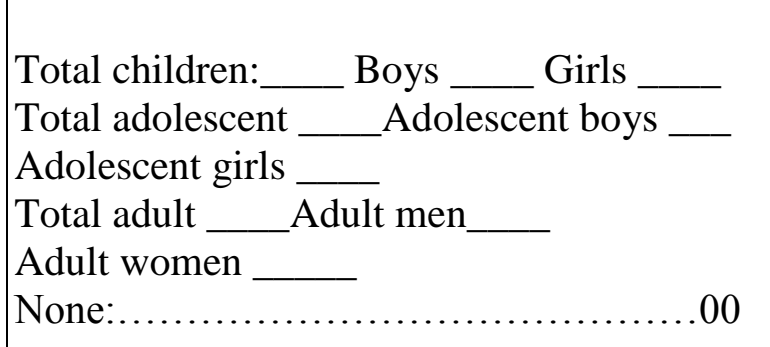 & \\
\hline 303 & $\begin{array}{l}\text { Generally, how long after the assault, } \\
\text { does a rape survivor reaches the police } \\
\text { station }\end{array}$ & $\begin{array}{l}\text { Within 3 hours } \\
\text { Between 3-6 hours } \\
\text { Between 7-12 hours } \\
\text { Between 13-18 hours } \\
\text { Between 19-24 hours } \\
\text { Second day } \\
\text { Third day } \\
\text { After more than } 3 \text { days } \\
\text { Don't Know } \\
\end{array}$ & \\
\hline 304 & $\begin{array}{l}\text { Who handles a rape survivor when } \\
\text { she/he comes to your police station? }\end{array}$ & 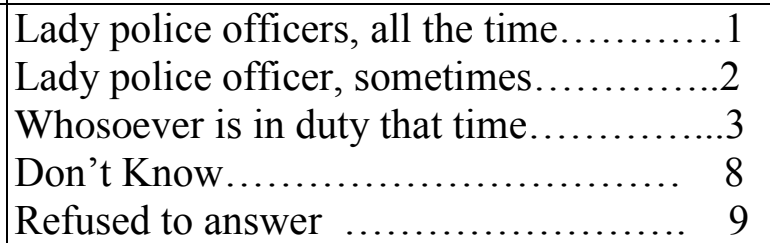 & \\
\hline 305 & $\begin{array}{l}\text { If there is no lady police officer on duty } \\
\text { at that time at police station or she is } \\
\text { not posted at the police station then who } \\
\text { attends the case? }\end{array}$ & 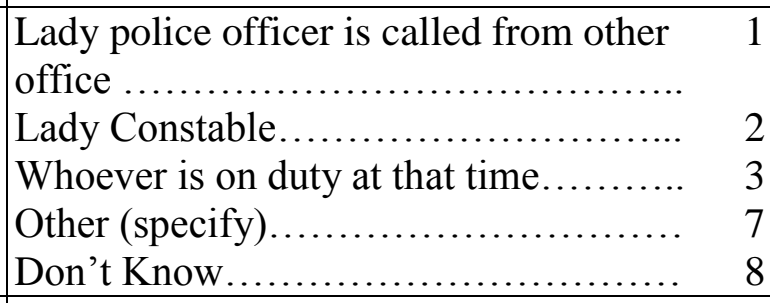 & $\begin{array}{l}=>\text { Skip } 307 \\
=>\text { Skip } 307\end{array}$ \\
\hline 306 & $\begin{array}{l}\text { Generally, what is the time gap from } \\
\text { the time lady officer is called to the } \\
\text { time she actually reaches the facility? }\end{array}$ & Minutes & \\
\hline
\end{tabular}




\begin{tabular}{|c|c|c|c|}
\hline & Questions and filters & Coding Categories & $\begin{array}{l}\text { Skip To/ } \\
\text { Codes }\end{array}$ \\
\hline 307 & $\begin{array}{l}\text { In your police station, where do rape } \\
\text { survivors usually wait before they are } \\
\text { interviewed? } \\
\text { (OBSERVE) }\end{array}$ & 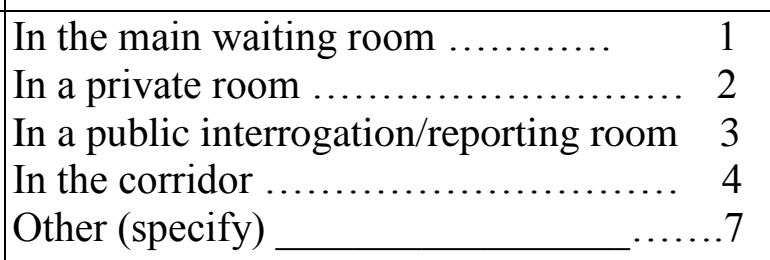 & \\
\hline 308 & $\begin{array}{l}\text { On arrival at police station, on average, } \\
\text { how long do sexual assault survivors } \\
\text { wait before they are interviewed or FIR } \\
\text { is written? }\end{array}$ & - (time in minutes) & \\
\hline 309 & $\begin{array}{l}\text { When a survivor reports to the police } \\
\text { station, about how long do they spend } \\
\text { with an officer discussing their case and } \\
\text { writing FIR? }\end{array}$ & 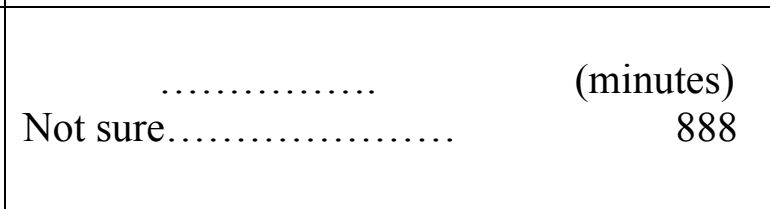 & \\
\hline 310 & $\begin{array}{l}\text { In your police station, where do } \\
\text { interview with sexual assault survivors } \\
\text { takes place? }\end{array}$ & $\begin{array}{l}\text { In a private room } \ldots \ldots \ldots \ldots \ldots \ldots \ldots \ldots \ldots \ldots \ldots \ldots \ldots \\
\text { In a public interrogation/reporting room } \\
\text { Other } \quad \ldots \ldots \ldots \ldots \ldots \ldots \ldots \ldots \ldots \ldots \ldots \ldots\end{array}$ & \\
\hline 311 & $\begin{array}{l}\text { If an adult rape survivor presents in a } \\
\text { highly agitated state or is continuously } \\
\text { weeping, what do you do first? }\end{array}$ & $\begin{array}{l}\text { Give sedatives } \\
\text { Attempt to calm through counseling } \\
\text { Have survivor wait for interview } \\
\text { until he/she is calm } \\
\text { Interview survivor in current state } \\
\text { Other (specify) }\end{array}$ & \\
\hline 312 & $\begin{array}{l}\text { Do adult rape survivors receive any } \\
\text { type of counseling at police station? }\end{array}$ & 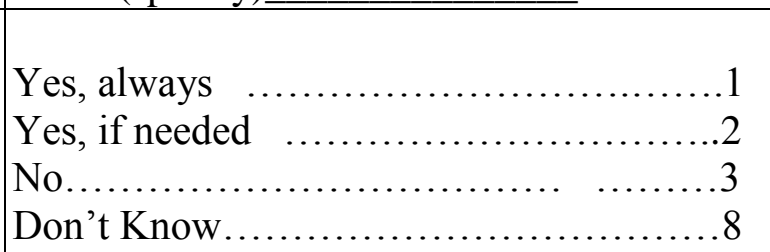 & $=>$ skip 316 \\
\hline 313 & If yes, who does it? & 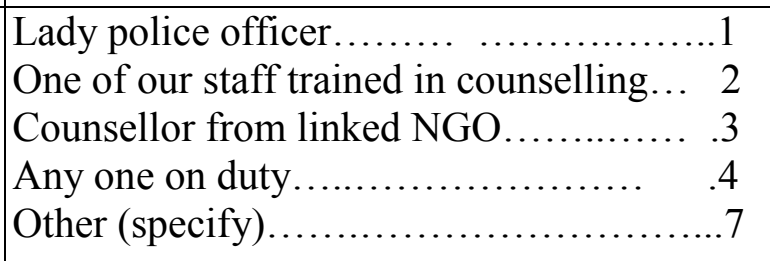 & $\begin{array}{l}=>\text { skip } 315 \\
=>\text { skip } 315\end{array}$ \\
\hline 314 & Is that person trained in counseling? & 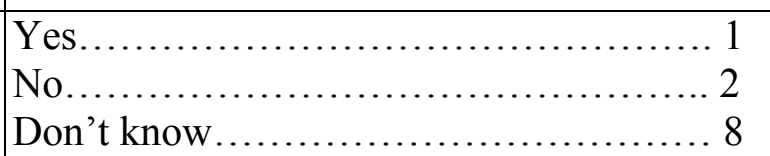 & \\
\hline
\end{tabular}




\begin{tabular}{|c|c|c|c|}
\hline & Questions and filters & Coding Categories & $\begin{array}{l}\text { Skip To/ } \\
\text { Codes }\end{array}$ \\
\hline 315 & $\begin{array}{l}\text { What topics are generally counseled or } \\
\text { what all points are emphasized? } \\
\text { INS: DO NOT READ. Circle which } \\
\text { all are applicable. }\end{array}$ & 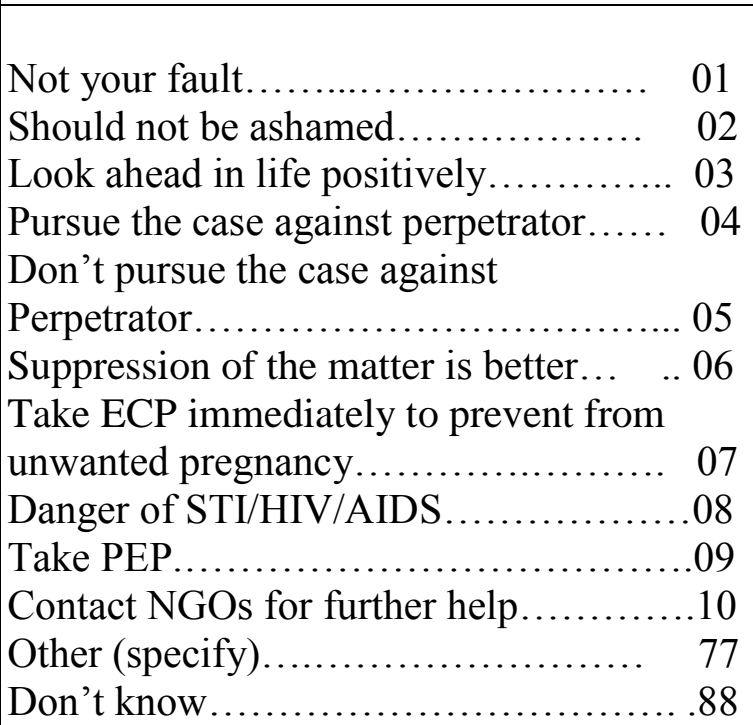 & \\
\hline
\end{tabular}




\section{Section 4: STI/HIV Prevention}

\begin{tabular}{|c|c|c|c|}
\hline & Questions and filters & Coding Categories & \begin{tabular}{|l} 
Skip To/ \\
Codes
\end{tabular} \\
\hline 401 & $\begin{array}{l}\text { How often the rape survivor is informed about } \\
\text { if danger of getting HIV or STI infection? }\end{array}$ & 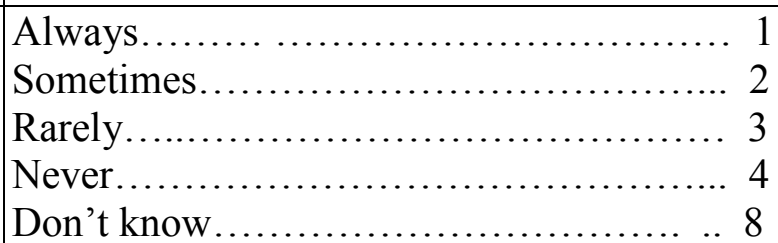 & \\
\hline 402 & $\begin{array}{l}\text { What information or points are emphasized } \\
\text { about HIV/AIDS to the rape survivors? }\end{array}$ & 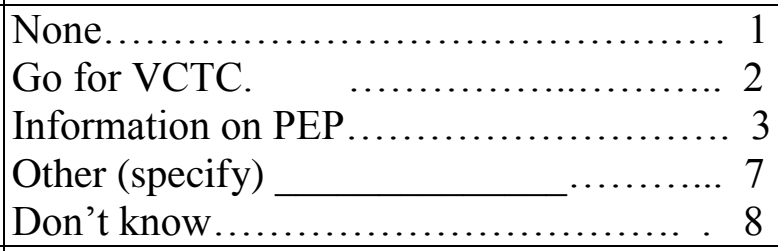 & \\
\hline 403 & $\begin{array}{l}\text { When interviewing a survivor, have you } \\
\text { suggested HIV testing? }\end{array}$ & $\begin{array}{ll}\text { Yes } & 1 \\
\text { No } & 2\end{array}$ & \\
\hline 404 & $\begin{array}{l}\text { If a survivor expresses interest in HIV testing, } \\
\text { what do you do? }\end{array}$ & 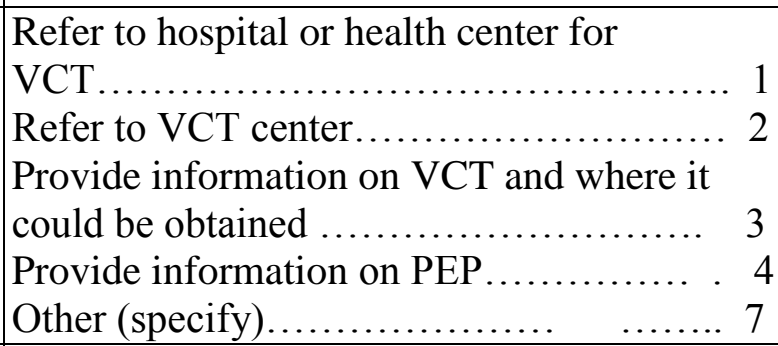 & \\
\hline 405 & $\begin{array}{l}\text { See 316. If PEP is not mentioned then ask. } \\
\text { Have you ever heard of post-exposure } \\
\text { prophylaxis (also known as PEP) for HIV? }\end{array}$ & 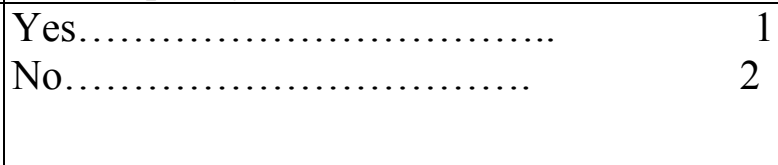 & $\begin{array}{l}=>\text { Skip } \\
\mathbf{5 0 1}\end{array}$ \\
\hline 406 & $\begin{array}{l}\text { What does PEP do? } \\
\text { (Record Verbatim) }\end{array}$ & & \\
\hline 407 & $\begin{array}{l}\text { What is the time limit within which PEP must } \\
\text { be taken after rape to be effective in preventing } \\
\text { HIV? }\end{array}$ & 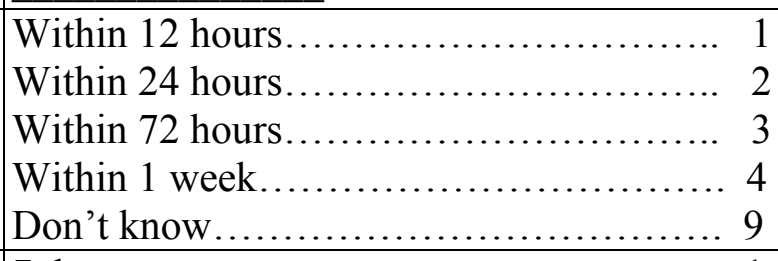 & \\
\hline 408 & How long does the course of PEP last? & 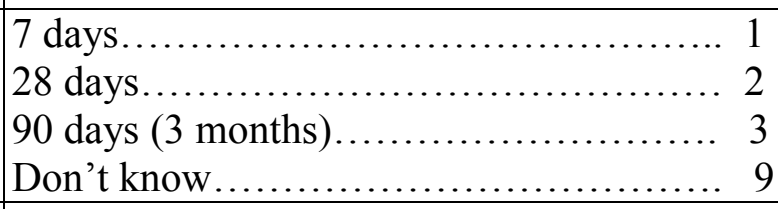 & \\
\hline 409 & $\begin{array}{l}\text { Is PEP } 100 \text { percent effective in preventing } \\
\text { HIV transmission? }\end{array}$ & 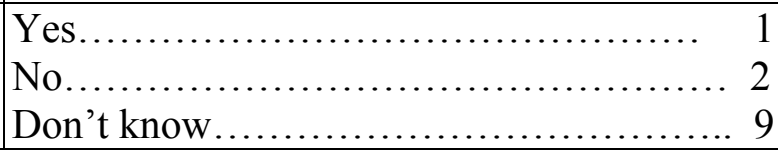 & \\
\hline
\end{tabular}




\section{Section 5: Pregnancy Prevention}

\begin{tabular}{|c|c|c|c|}
\hline & Questions and filters & Coding Categories & $\begin{array}{l}\text { Skip To/ } \\
\text { Codes }\end{array}$ \\
\hline 501 & $\begin{array}{l}\text { How often do you personally discuss the } \\
\text { possibility of unwanted pregnancy with rape } \\
\text { survivors? }\end{array}$ & 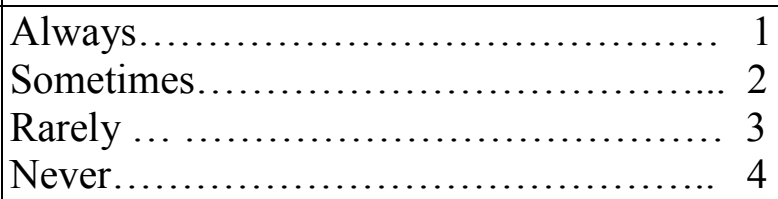 & \\
\hline 502 & $\begin{array}{l}\text { Have you ever heard of emergency } \\
\text { contraception (EC) or the "morning after pill"/ } \\
\text { I-pills /E-pills? }\end{array}$ & 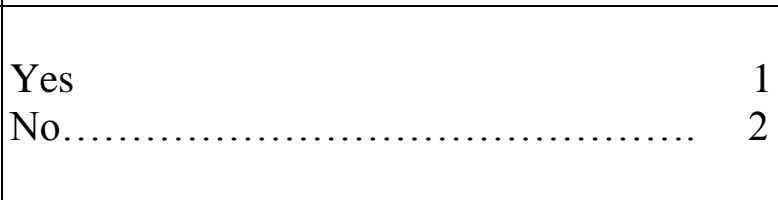 & $\begin{array}{l}=>\text { Skip } \\
\mathbf{6 0 1}\end{array}$ \\
\hline \begin{tabular}{|l|}
503 \\
\end{tabular} & $\begin{array}{l}\text { If yes, what does emergency contraception } \\
\text { (EC) do? } \\
\text { (Circle only ONE response) }\end{array}$ & 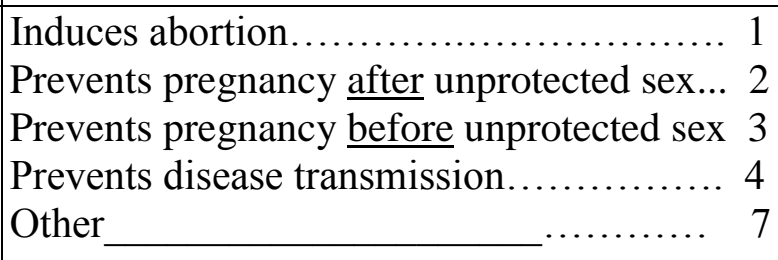 & \\
\hline 504 & $\begin{array}{l}\text { What is the minimum age to give emergency } \\
\text { contraceptive pill (ECP)? }\end{array}$ & $\begin{array}{l}\text { To all women who is menstruating.......... } 1 \\
\text { Any girl/woman above } 10 \text { years of age..... } \\
\text { Other answers (note) } \ldots \ldots \ldots \ldots \ldots \ldots \ldots \ldots \ldots \ldots\end{array}$ & \\
\hline 505 & $\begin{array}{l}\text { Does your police station stock ECP and offer it } \\
\text { to rape survivors? }\end{array}$ & 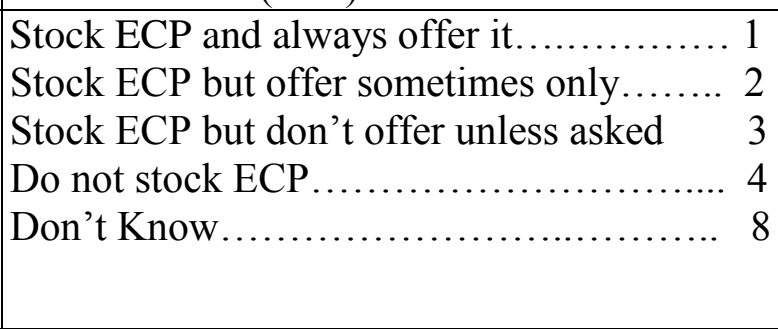 & $\begin{array}{l} \\
=>\text { Skip } \\
601 \\
=>\text { Skip } \\
\text { 601 }\end{array}$ \\
\hline \begin{tabular}{|l|}
506 \\
\end{tabular} & $\begin{array}{l}\text { Is any emergency contraception pill (ECP) in } \\
\text { stock today (ask for a pack). }\end{array}$ & \begin{tabular}{|ll} 
Yes, provide the pack $\ldots \ldots \ldots \ldots \ldots \ldots \ldots \ldots \ldots \ldots \ldots \ldots$ & 1 \\
Yes, could not provide pack $\ldots \ldots \ldots \ldots \ldots \ldots$ & 2 \\
No $\ldots \ldots \ldots \ldots \ldots \ldots \ldots \ldots \ldots \ldots \ldots \ldots \ldots \ldots \ldots \ldots$. & 3
\end{tabular} & \\
\hline 507 & $\begin{array}{l}\text { Have you ever given emergency contraceptive } \\
\text { (EC) to a rape survivor? }\end{array}$ & 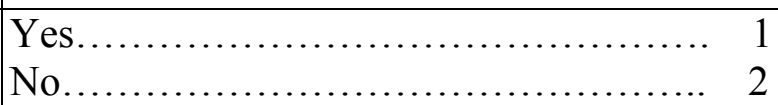 & \\
\hline 508 & $\begin{array}{l}\text { Is it necessary to conduct a pregnancy test } \\
\text { prior to administering emergency } \\
\text { contraceptive (EC) pills? }\end{array}$ & 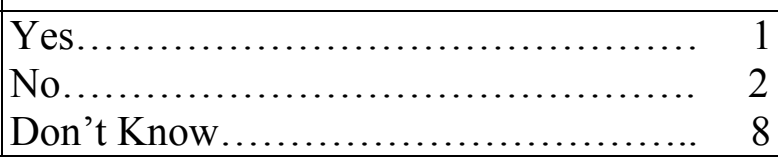 & \\
\hline 509 & $\begin{array}{l}\text { What is the time limit within which emergency } \\
\text { contraception pill (ECP) must be taken to be } \\
\text { effective? } \\
\text { (INS: Circle only ONE response) }\end{array}$ & 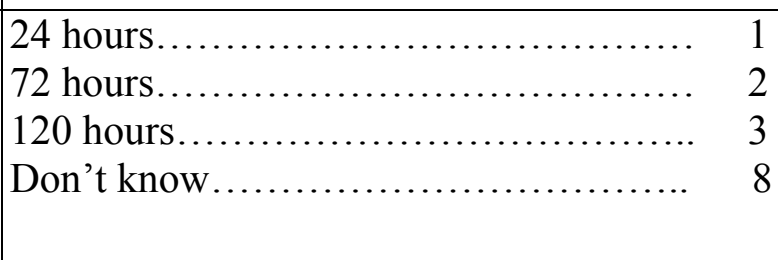 & \\
\hline
\end{tabular}




\begin{tabular}{|c|c|c|}
\hline 510 & $\begin{array}{l}\text { Where can emergency contraceptive (EC) be } \\
\text { obtained? } \\
\text { (INS: Multiple Responses possible. Take up } \\
\text { to TWO answers). }\end{array}$ & 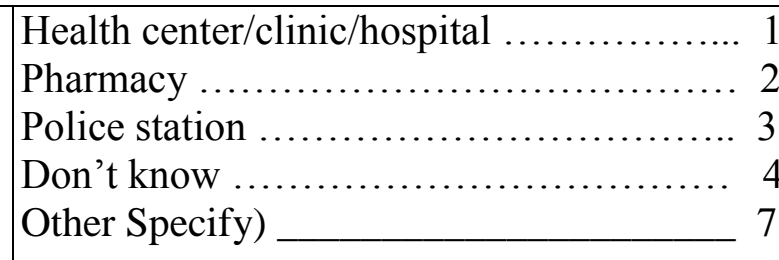 \\
\hline \begin{tabular}{|l|}
511 \\
\end{tabular} & $\begin{array}{l}\text { ECP and PEP should be stored at the police } \\
\text { station to provide all rape survivors coming to } \\
\text { the police station. Do you agree or disagree? }\end{array}$ & $\begin{array}{l}\text { Yes } \ldots \ldots \ldots \\
\text { No } \ldots \ldots \ldots \ldots \ldots \ldots \ldots\end{array}$ \\
\hline
\end{tabular}




\section{Section 6: Child Survivors}

\begin{tabular}{|c|c|c|c|}
\hline & Questions and filters & Coding Categories & $\begin{array}{l}\text { Skip To/ } \\
\text { Codes }\end{array}$ \\
\hline 601 & $\begin{array}{l}\text { In your experience who most often } \\
\text { accompanies a minor rape survivor? } \\
\text { INS: Multiple responses possible. Take up } \\
\text { to TWO answers }\end{array}$ & 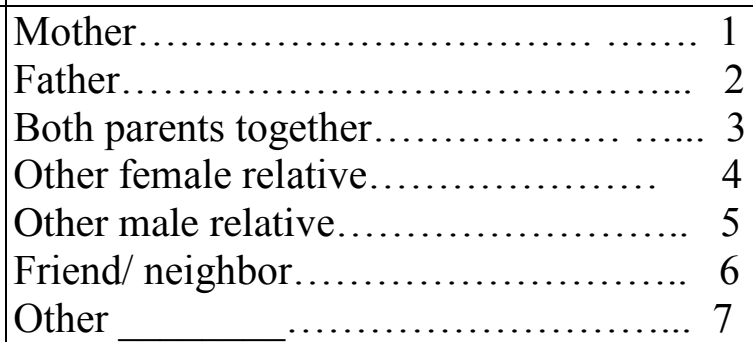 & \\
\hline 602 & $\begin{array}{l}\text { Is it necessary to attempt to obtain consent } \\
\text { from a child who is old enough to speak before } \\
\text { interviewing or discussing with her? }\end{array}$ & 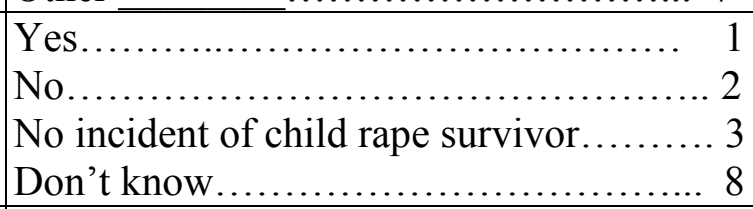 & \\
\hline 603 & $\begin{array}{l}\text { When a child is old enough to speak for } \\
\text { her/himself, how often do parents participate } \\
\text { in the interview? }\end{array}$ & 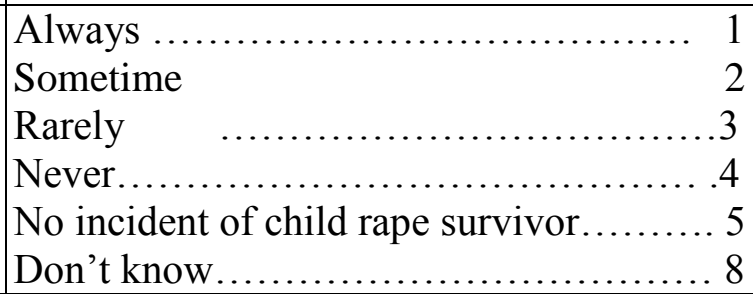 & $=>$ Skip 701 \\
\hline 604 & $\begin{array}{l}\text { Do you use any visual aid when } \\
\text { interviewing/interrogating a minor rape } \\
\text { survivor? }\end{array}$ & 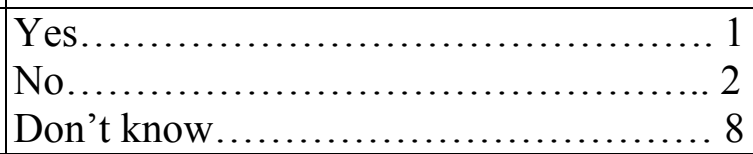 & \\
\hline 605 & $\begin{array}{l}\text { What visual aids generally do you use? } \\
\text { (PROBE: any other thing do you use?) }\end{array}$ & 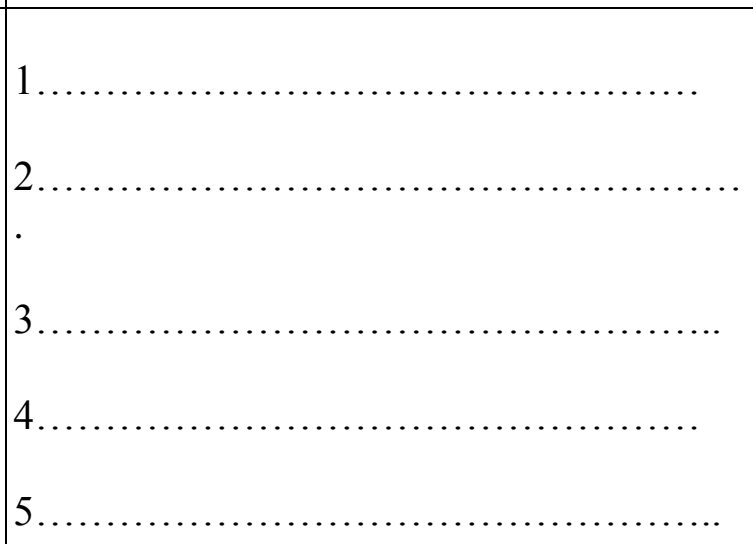 & \\
\hline 606 & $\begin{array}{l}\text { "Children should NOT be interviewed in the } \\
\text { presence of the suspected offender, } \\
\text { irrespective of who he is (parent/guardian)" }\end{array}$ & 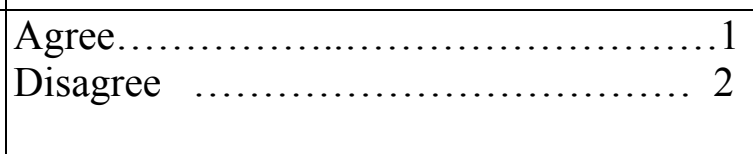 & \\
\hline
\end{tabular}




\section{Section 7: Forensic Evidence}

\begin{tabular}{|c|c|c|c|}
\hline & Questions and filters & Coding Categories & $\begin{array}{l}\text { Skip To/ } \\
\text { Codes }\end{array}$ \\
\hline \multirow[t]{2}{*}{701} & $\begin{array}{l}\text { What is meant by the term "forensic } \\
\text { evidence?" } \\
\text { INS: Multiple responses possible. Take up } \\
\text { to THREE answers }\end{array}$ & $\begin{array}{l}\text { Samples collected for legal purposes } \\
\text { Samples collected for use in treating the } \\
\text { survivor } \\
\text { Collecting clothes/debris of rape } \\
\text { survivor } \\
\text { Collecting any material which could } \\
\text { provide evidence for assault } \\
\text { Other (write verbatim }\end{array}$ & \\
\hline & & Don't know & \\
\hline 702 & $\begin{array}{l}\text { In what situations should forensic evidence be } \\
\text { collected? }\end{array}$ & $\begin{array}{l}\text { In all cases } \\
\text { Only when survivor intends to } \\
\text { prosecute } \\
\text { Only when the police order evidence } \\
\text { collection } \\
\text { Only for child survivors } \\
\text { Don't know }\end{array}$ & \\
\hline 703 & $\begin{array}{l}\text { Do you go for collection of evidence after } \\
\text { medical examination at hospital is done and } \\
\text { rape is confirmed? }\end{array}$ & 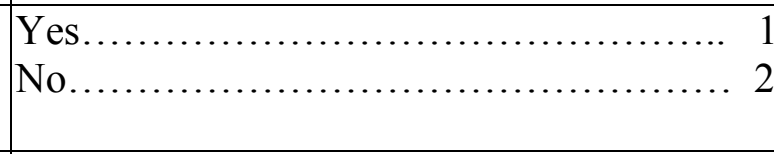 & \\
\hline 704 & $\begin{array}{l}\text { If yes, what kind of evidence? } \\
\text { INS: Multiple responses possible. Take up } \\
\text { to THREE answers }\end{array}$ & & \\
\hline 705 & $\begin{array}{l}\text { Have you ever personally collected forensic } \\
\text { evidence from a survivor? }\end{array}$ & 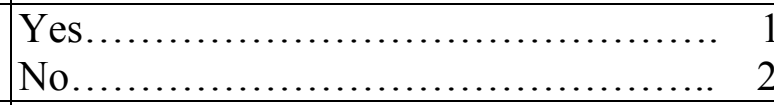 & $\begin{array}{l}\text { =>Skip } \\
708\end{array}$ \\
\hline 706 & $\begin{array}{l}\text { If no, who collects forensic evidence? } \\
\text { INS: Multiple responses possible. Take up } \\
\text { to TWO answers }\end{array}$ & 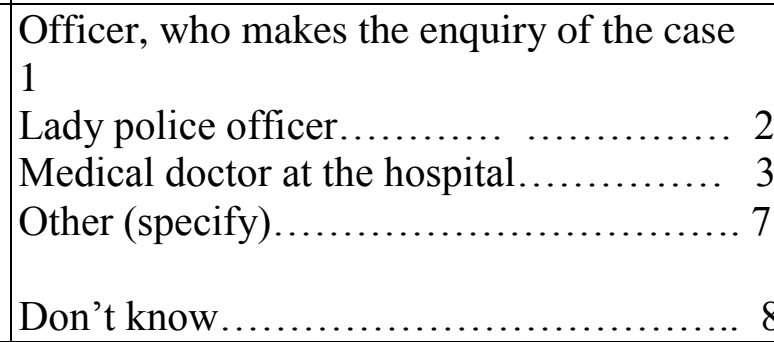 & \\
\hline 707 & $\begin{array}{l}\text { What is the duration after a sexual assault } \\
\text { evidences should be collected for accurate and } \\
\text { effective forensic samples? }\end{array}$ & 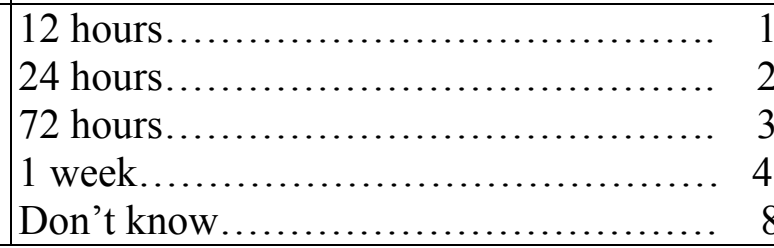 & \\
\hline
\end{tabular}




\begin{tabular}{|c|c|c|c|}
\hline & Questions and filters & Coding Categories & \begin{tabular}{|l} 
Skip To/ \\
Codes
\end{tabular} \\
\hline 708 & $\begin{array}{l}\text { What type of containers is used to collect } \\
\text { clothing or debris of rape survivors? }\end{array}$ & 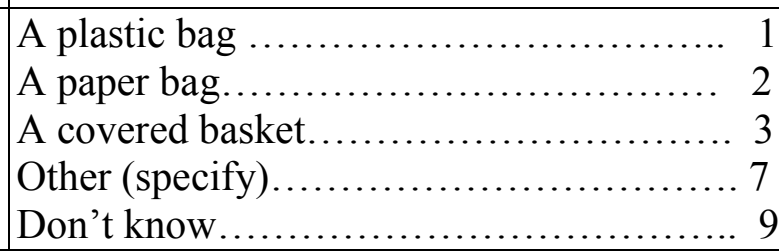 & \\
\hline 709 & $\begin{array}{l}\text { Do you have standard procedures for } \\
\text { maintaining the 'all the evidences collected'? }\end{array}$ & 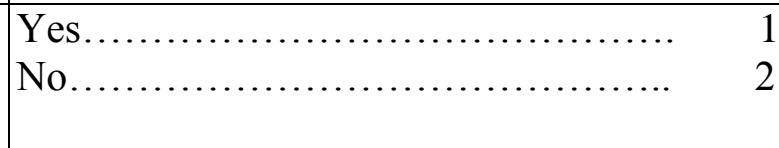 & $\begin{array}{l}\text { =>Skip } \\
711\end{array}$ \\
\hline \begin{tabular}{|l|}
710 \\
\end{tabular} & $\begin{array}{l}\text { If yes, please describe these procedures. } \\
\text { INS: multiple responses possible. Take up to } \\
\text { TWO answers. }\end{array}$ & & \\
\hline 711 & $\begin{array}{l}\text { Is there any protocol describing procedure for } \\
\text { maintaining the evidences? }\end{array}$ & 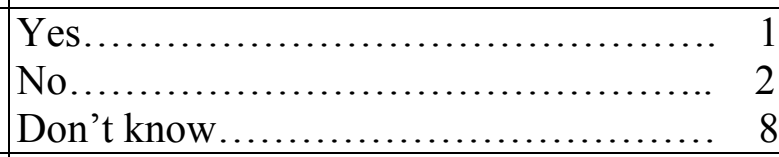 & \\
\hline 712 & $\begin{array}{l}\text { Is this presently available with you? } \\
\text { (ask to show) }\end{array}$ & 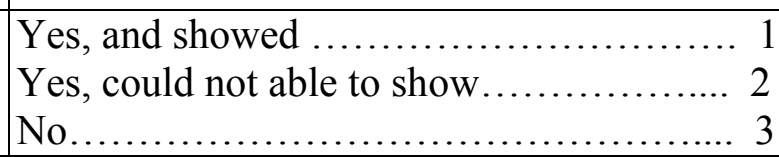 & \\
\hline 713 & $\begin{array}{l}\text { What are the evidences collected before and } \\
\text { after receiving medical management at the } \\
\text { hospital once rape is established by the police? } \\
\text { INS: Multiple responses possible. Take up } \\
\text { to THREE answers }\end{array}$ & & \\
\hline 714 & $\begin{array}{l}\text { Is there a different procedure for children? } \\
\text { INS: Multiple responses possible. Take up } \\
\text { to THREE answers }\end{array}$ & & \\
\hline
\end{tabular}




\section{Section 8: Referral and support services}

\begin{tabular}{|c|c|c|c|}
\hline & Questions and filters & Coding Categories & $\begin{array}{l}\text { Skip To/ } \\
\text { Codes }\end{array}$ \\
\hline \begin{tabular}{|l|}
801 \\
\end{tabular} & $\begin{array}{l}\text { About what percentage of survivors report about the } \\
\text { assault to the police station first? }\end{array}$ & 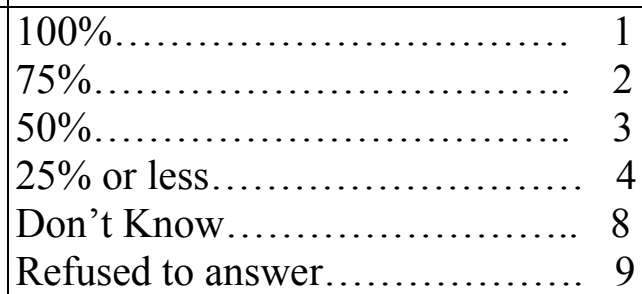 & \\
\hline \begin{tabular}{|l|}
802 \\
\end{tabular} & $\begin{array}{l}\text { Who is most likely to refer a sexual assault survivor } \\
\text { to police station? } \\
\text { INS: Multiple answers possible. Code up to TWO } \\
\text { answers. }\end{array}$ & 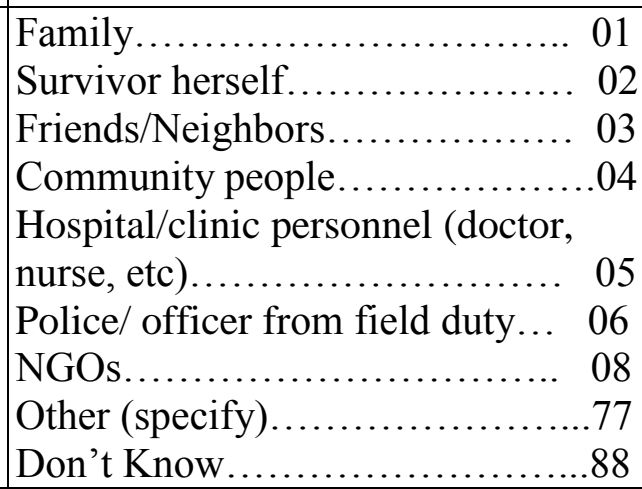 & \\
\hline \begin{tabular}{|l|}
803 \\
\end{tabular} & $\begin{array}{l}\text { How often do lady police accompany survivors to a } \\
\text { health facility? }\end{array}$ & 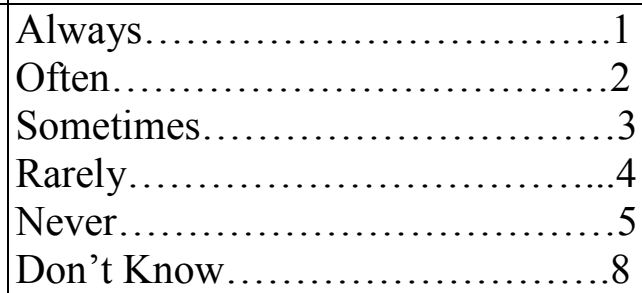 & \\
\hline 804 & $\begin{array}{l}\text { If lady police officer is not available who } \\
\text { accompanies the rape survivor? } \\
\text { INS: Multiple answers possible. Take up to TWO } \\
\text { answers. }\end{array}$ & 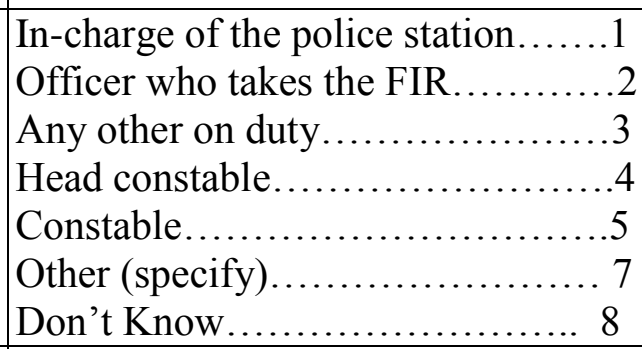 & \\
\hline \begin{tabular}{|l}
805 \\
\end{tabular} & $\begin{array}{l}\text { If survivors do not report to police station first, } \\
\text { where are they most likely to go for assistance? } \\
\text { INS: Multiple answers possible. Take up to TWO } \\
\text { answers. }\end{array}$ & 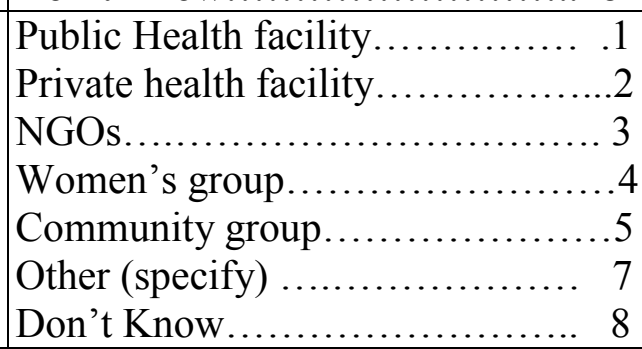 & \\
\hline \begin{tabular}{|l}
806 \\
\end{tabular} & $\begin{array}{l}\text { If the survivor presents first at the public health } \\
\text { facility, how often are the police called by the health } \\
\text { provider? }\end{array}$ & 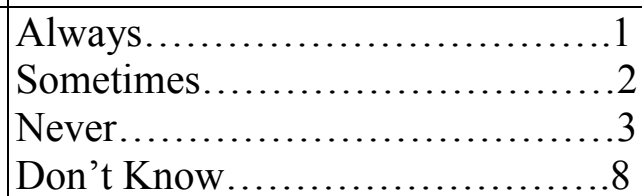 & \\
\hline
\end{tabular}




\begin{tabular}{|c|c|c|c|}
\hline & Questions and filters & Coding Categories & $\begin{array}{l}\text { Skip To/ } \\
\text { Codes }\end{array}$ \\
\hline 807 & $\begin{array}{l}\text { In your opinion, how well do police and health } \\
\text { facility staff work together in rape cases? }\end{array}$ & $\begin{array}{l}\text { Always work well together........... } \\
\text { Sometimes work well together......2 } \\
\text { Depends whether the survivor wants } \\
\text { to pursue the case..................... } 3 \\
\text { Never work well together............ } \\
\text { Don't know........................... }\end{array}$ & \\
\hline 808 & $\begin{array}{l}\text { How often do you refer survivors for legal advice or } \\
\text { support? }\end{array}$ & 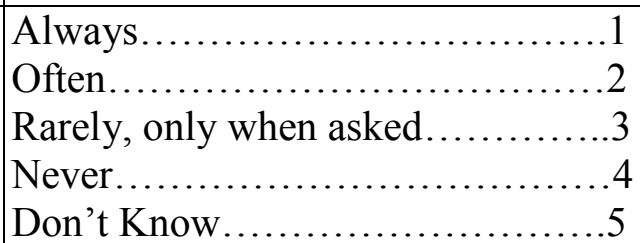 & \\
\hline 809 & $\begin{array}{l}\text { Where do you refer survivors for legal advice or } \\
\text { support? } \\
\text { INS: Multiple answers possible. }\end{array}$ & 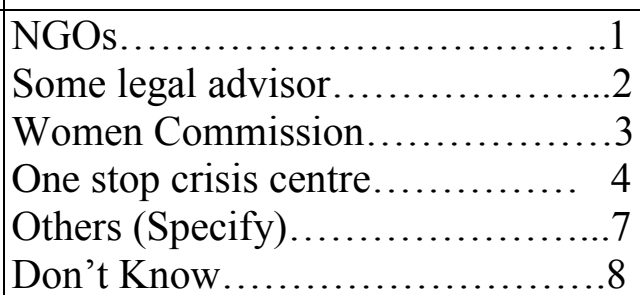 & \\
\hline 810 & $\begin{array}{l}\text { In your opinion why many rape survivors do not } \\
\text { report to police? } \\
\text { INS: Multiple answers possible. }\end{array}$ & - & \\
\hline 811 & $\begin{array}{l}\text { What could be done to increase reporting of rape } \\
\text { survivors to police? } \\
\text { INS: Multiple answers possible. }\end{array}$ & 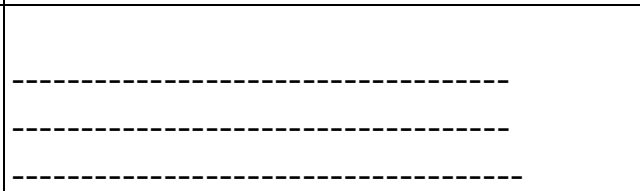 & \\
\hline 812 & $\begin{array}{l}\text { Is posting a woman officer to each police station or } \\
\text { for a group of police stations (say 2-3 police stations) } \\
\text { could increase reporting? }\end{array}$ & 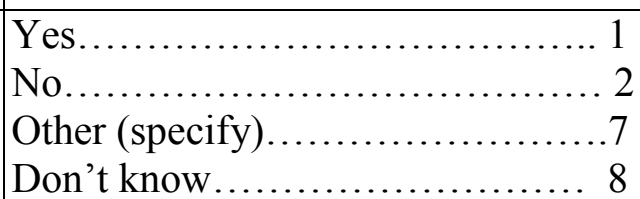 & \\
\hline 813 & $\begin{array}{l}\text { Will you support training of at least } 2 \text { officers/head } \\
\text { constables in each police station in managing rape } \\
\text { survivors? }\end{array}$ & 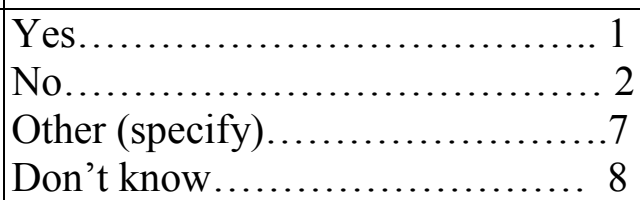 & \\
\hline
\end{tabular}




\section{Section 9: Laws and procedures}






\begin{tabular}{|c|c|c|c|}
\hline & Questions and filters & Coding Categories & $\begin{array}{l}\text { Skip To/ } \\
\text { Codes }\end{array}$ \\
\hline 906 & $\begin{array}{l}\text { In your opinion, what are the THREE most common } \\
\text { reasons that sexual assault cases are not pursued in } \\
\text { court }\end{array}$ & 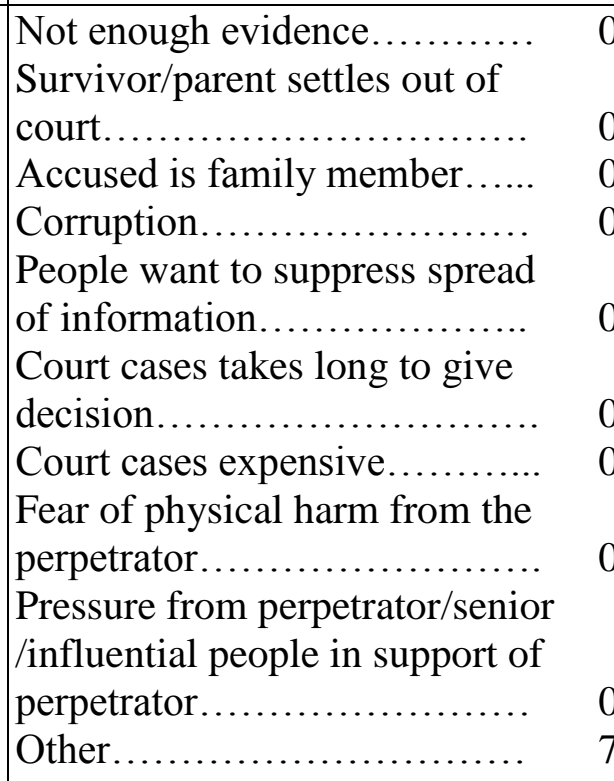 & \\
\hline 907 & $\begin{array}{l}\text { In your opinion in what percentage of cases the } \\
\text { perpetrator are convicted? }\end{array}$ & 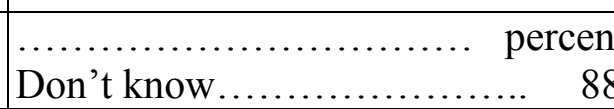 & \\
\hline 908 & $\begin{array}{l}\text { Can a rape survivor get medical attention without } \\
\text { opening a case for prosecution if the survivor wants } \\
\text { so? }\end{array}$ & 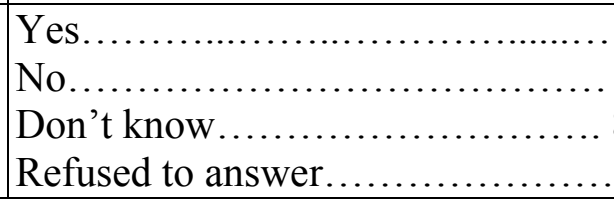 & \\
\hline
\end{tabular}




\section{Section 10: Attitudes and perceptions}

\begin{tabular}{|c|c|c|c|c|c|}
\hline & Questions and filters & \multicolumn{3}{|c|}{ Coding Categories } & $\begin{array}{l}\text { Skip To/ } \\
\text { Codes }\end{array}$ \\
\hline 1001 & $\begin{array}{l}\text { How common do you think rape is in your } \\
\text { community? }\end{array}$ & \multicolumn{3}{|c|}{ 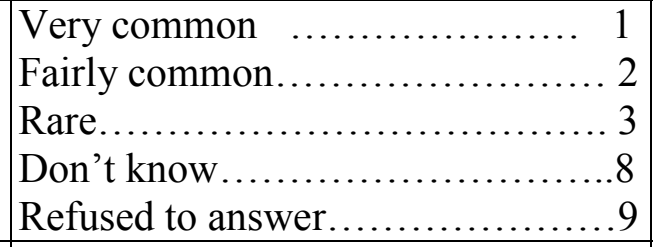 } & \\
\hline 1002 & $\begin{array}{l}\text { How does the community treat cases of rape } \\
\text { survivors? }\end{array}$ & \multicolumn{3}{|c|}{ 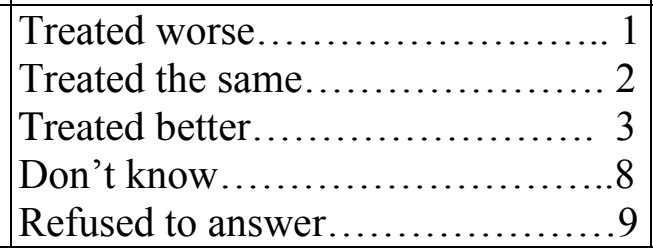 } & \\
\hline \multirow[t]{2}{*}{1003} & \multicolumn{5}{|c|}{$\begin{array}{l}\text { What follows is a list of statements. There is no right or wrong answers. We would like you to tell us } \\
\text { whether you generally agree or disagree with each statement. }\end{array}$} \\
\hline & & Agree & $\begin{array}{l}\text { Neutral/ } \\
\text { DK }\end{array}$ & Disagree & $\begin{array}{l}\text { Not } \\
\text { answere } \\
\text { d }\end{array}$ \\
\hline $\mathrm{a}$ & A boy can be sexually abused & 1 & 2 & 3 & 9 \\
\hline $\mathrm{b}$ & A husband can rape his wife & 1 & 2 & 3 & 9 \\
\hline $\mathrm{c}$ & Forced sex with sex workers cannot be called rape & 1 & 2 & 3 & 9 \\
\hline $\mathrm{d}$ & $\begin{array}{l}\text { If a woman is drunk, it is impossible to say that she } \\
\text { refused sex and got raped }\end{array}$ & 1 & 2 & 3 & 9 \\
\hline $\mathrm{e}$ & Some women lie about rape to punish men & 1 & 2 & 3 & 9 \\
\hline $\mathrm{f}$ & $\begin{array}{l}\text { Rape happens because women move around } \\
\text { unescorted and carelessly. }\end{array}$ & 1 & 2 & 3 & 9 \\
\hline $\mathrm{g}$ & $\begin{array}{l}\text { Provocative dress and gestures of women are often, } \\
\text { the cause of rape. }\end{array}$ & 1 & 2 & 3 & 9 \\
\hline $\mathrm{h}$ & Only certain types of women are raped & 1 & 2 & 3 & 9 \\
\hline $\mathrm{i}$ & A woman who is raped brings shame on her family & 1 & 2 & 3 & 9 \\
\hline $\mathrm{j}$ & $\begin{array}{l}\text { It is disgraceful for women to bring rape cases to } \\
\text { court }\end{array}$ & & & & \\
\hline $\mathrm{k}$ & $\begin{array}{l}\text { A woman who has been raped could have a serious } \\
\text { medical problem }\end{array}$ & 1 & 2 & 3 & 9 \\
\hline 1 & $\begin{array}{l}\text { A child who has been raped is an emergency medica } \\
\text { case }\end{array}$ & & & & \\
\hline $\mathrm{m}$ & $\begin{array}{l}\text { A person rarely dies from injuries after rape and so } \\
\text { they should wait for their turn for health care }\end{array}$ & 1 & 2 & 3 & 9 \\
\hline $\mathrm{n}$ & Rape is more serious for someone who is a virgin & & & & \\
\hline o & Rape leaves obvious signs of physical injury & 1 & 2 & 3 & 9 \\
\hline $\mathrm{p}$ & $\begin{array}{l}\text { Very delayed punishment or non-punishment of } \\
\text { perpetrators encourages rape. }\end{array}$ & 1 & 2 & 3 & 9 \\
\hline
\end{tabular}




\section{Section 11: Domestic Violence}

\begin{tabular}{|c|c|c|c|}
\hline & Questions and filters & Coding Categories & $\begin{array}{l}\text { Skip To/ } \\
\text { Codes }\end{array}$ \\
\hline 1101 & $\begin{array}{l}\text { How often do women present with complaints of } \\
\text { violence from husbands/ partners? }\end{array}$ & 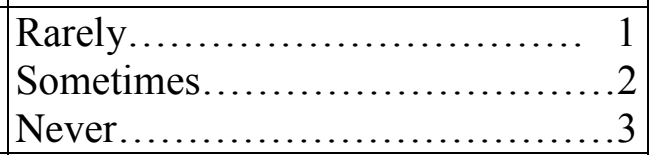 & \\
\hline 1102 & $\begin{array}{l}\text { What types of violence are reported? } \\
\text { INS: Multiple responses possible. Take up to } \\
\text { THREE answers. }\end{array}$ & 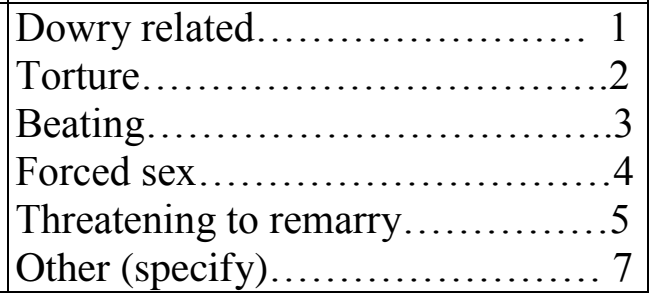 & \\
\hline 1103 & $\begin{array}{l}\text { During the last } 5 \text { years has the reporting by wives } \\
\text { against husbands/partners increased or remained the } \\
\text { same or has declined? }\end{array}$ & $\begin{array}{l}\text { Increased } \ldots \ldots \ldots \ldots \ldots \ldots \ldots \ldots \ldots \ldots \\
\text { Remained the same................... } \\
\text { Declined } \ldots \ldots \ldots \ldots \ldots \ldots \ldots \ldots \ldots\end{array}$ & \\
\hline 1104 & Do all of the reported cases turn out to be correct? & 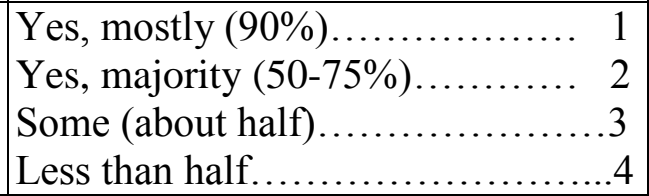 & \\
\hline 1105 & What percentage of cases goes to prosecution? & ..........................percent & \\
\hline 1106 & What percentage of cases is prosecuted? & .......percent & \\
\hline
\end{tabular}

Thanks for your valuable time. 